Portland State University

PDXScholar

$1-1-2011$

\title{
The Institutional Development of the American Vice Presidency
}

James Emory Hite

Portland State University

Follow this and additional works at: https://pdxscholar.library.pdx.edu/open_access_etds Let us know how access to this document benefits you.

Recommended Citation

Hite, James Emory, "The Institutional Development of the American Vice Presidency" (2011).

Dissertations and Theses. Paper 354.

https://doi.org/10.15760/etd.354

This Thesis is brought to you for free and open access. It has been accepted for inclusion in Dissertations and Theses by an authorized administrator of PDXScholar. Please contact us if we can make this document more accessible: pdxscholar@pdx.edu. 
The Institutional Development of the American Vice Presidency

\title{
by
}

James Emory Hite

A thesis submitted in partial fulfillment of the requirements for the degree of

\author{
Master of Science \\ in \\ Political Science
}

\author{
Thesis Committee: \\ Melody Rose, chair \\ Richard Clucas \\ Chris Shortell
}

\section{Portland State University}

(C)2011 


\begin{abstract}
The ongoing disregard for the American vice presidency, and for those who would and do hold the office, in conjunction with the scarcity of academic research devoted specifically to the development of the institution, warrants the following study. Indeed, this study is relatively novel to the existent body of political science research which ventures to evaluate the vice presidency. Generally, research and publications on the vice presidency have tended to focus on variables such as ticket-balancing and homestate advantage; critiques of individual vice presidents; and more recently, specific policy spheres where modern vice presidents have been involved. In contrast, this project is devoted exclusively to isolating the institutional markers that have increased the broad utility of the position of vice president of the United States and, in the process, have augmented the development of the vice-presidential institution. These institutional markers include augmentation by precedent, statute, and constitutional amendment; increases in the resources made available to the institution; the addition of institutional identifiers; and the gradual accumulation of policy portfolios and responsibilities assigned to vice presidents. Underscoring each of the preceding institutional markers has been the vital role specific presidents have played in facilitating the development of the vice-presidential institution; indeed, the form and the substance of the vice presidency today is almost entirely the product of presidential initiative.

In total, this study represents an interpretive synthesis of the historical record of the American vice presidency and how that record reflects the development of the institution. In the end, salient institutional markers have led to the development of a modern, utilitarian institution, one that is now fully integrated into the executive
\end{abstract}


government. Of equal import, the standing of the vice presidency today, legitimizes the individual serving in the office, and furthers the influence of the vice president in the executive government. And, in telling the story of the development of the vice presidency, it is readily apparent that a combination of anecdotal and empirical evidence support the thesis of a changed institution, closely integrated with, and dependent upon, the presidency. 
This thesis is dedicated to Dylan, Max, Calvin, and Lisa:

You are my love, you are my life. 


\section{Acknowledgments}

Upon the completion of my thesis I would like to acknowledge the encouragement and support of several people. To start, I wish to offer my sincere thanks and gratitude to the members of my thesis committee--professors Melody Rose, Richard Clucas, and Chris Shortell--for their willingness to participate in this project; for their helpful suggestions regarding the form the thesis eventually took; and for their constructive comments at my thesis defense. I also wish to acknowledge the significant role Professor Rose played throughout the development of my thesis. As I worked my way through the political science master's program, Professor Rose was a proficient academic advisor to me and an outstanding teacher. As such, I am grateful for all she has done for my academic and professional career, and though it is surely not enough: thank you Professor Rose.

I also want to take this opportunity to acknowledge my family, beginning with my parents, Max and Marty Hite. Their love and encouragement in every endeavor I pursed never wavered. Although they are no longer here, every day they are present in my mind and in my heart.

My children, Dylan, Max, and Calvin, bring me so much joy. They have been patient and supportive as my research and writing on the vice presidency has taken a great deal of time. Over the previous three years they have played "categories" on long car rides, agreeing to vice presidents as the topic, all the while knowing I was sure to win. They have gamely listened to stories of the vice presidents that I uncovered in my research. And they have asked questions about my work that often times has led me to a new way of thinking about a particular facet of the vice presidency. In the process, I can 
state with confidence that they have become the three most informed young people on the American vice presidency in the nation. They are a never ending source of inspiration, laughter, and love.

Finally, I gratefully acknowledge the love and support of my wife Lisa. With the thesis project and with my book manuscript, Lisa has been there for me every step of the way, as she is in every facet of our life. She is a continuous source of encouragement and praise and never fails to assure me that every word I write is the best she has ever read. 
Table of Contents

Abstract

$\begin{array}{ll}\text { Dedication } & \text { iii }\end{array}$

Acknowledgements $\quad$ iv

List of Tables vii

Preface viii

1 Introduction: Why Study the Development of the American Vice Presidency? 1

2 The Establishment of the American Vice Presidency 12

3 Institutional Development by Constitutional Directive: 28

The Twelfth Amendment

4 The Vice President as Presidential Successor 51

5 Precedent by Presidential Prerogative: The Cabinet 60

6 Institutional Development by Portfolio and Statue 67

7 Institutional Development by Constitutional Directive: 109

The Twenty-fifth Amendment

8 The Vice Presidency Augmented: By Resources, Institutional Identifiers, 116 and Access

9 Conclusion: The Vice Presidency Today 125

$\begin{array}{ll}\text { Endnotes } & 132\end{array}$

$\begin{array}{ll}\text { Bibliography } & 148\end{array}$

Appendix A The Twelfth Amendment to the United States Constitution 156

Append B The Presidential Succession Act of $1947 \quad 158$

Appendix C The Twenty-fifth Amendment to the United States Constitution 161 


\section{List of Tables}

Table 1.1 Vacancies in the Vice Presidency 


\section{Preface}

In the course of four years research--conducted for this thesis, as well as for three published articles and a forthcoming book--original source documents, personal interviews and communications, oral histories, diaries, published notes, autobiographies, biographies, records of Congress, journal articles, and periodicals have all been utilized in an effort to comprehensively examine and thus better understand the American vice presidency. The resources cover a lengthy span of time and include material written in the eighteenth, nineteenth, twentieth and twenty-first centuries; for this reason, it is necessary to address the etymology, as it were, of the words vice president, vice presidency, and vice-presidential, and how the form these words have taken have varied over time.

For example, this has included capitalizing both words (Vice President); and hyphenating and capitalizing each (Vice-President); and has similarly been applied to commensurate variations for all forms of the words. In addition, hyphenation has been applied to all forms, even when presented in lower case script (vice-presidency). In order to remain true to original source documents, all quotations are reproduced as is, hence reflecting the accepted capitalization and hyphenation for the time period the material was written. This rule has been adhered to with more recent material, as well; the only exception being transcripts of the debates between the vice-presidential candidates, which are originally transcribed only for the exactness of the words spoken in the debate, and without concern to the preciseness of the written word.

In light of the foregoing considerations, it is impossible to maintain consistency throughout the thesis, and remain true to original source documents. Oftentimes, such 
inconsistencies apply to the various forms used when writing about the president, as well as other words that, in retrospect, appear to be capitalized at random. For this thesis, however, the appropriate capitalization and hyphenation for vice president and president have been used--and in all forms--as delineated by the Chicago Manual of Style, $15^{\text {th }}$ edition; therefore, these are acknowledged as the correct forms for the words at this time. Another note on the use of various reference materials: although the temptation is great for modern researchers to simply gather information from websites whenever possible, on those occasions when material was initially located via the internet, hard copies were obtained directly at a university library location, or by way of the interlibrary loan system. Not only does this practice ensure the accuracy of page citations, it is, quite simply, an antiquated preference of this author to have the actual material in hand. As it were, whether it was bound copies of long-forgotten journal articles retrieved from the basement of a library; or a well-worn copy of a manuscript which traveled across the country, courtesy of a generous lending-library; original hard copies of reference materials have consistently been accessed, including material from the author's extensive personal collection. And for any material initially retrieved online: thank you, fittingly, to Vice President Al Gore for inventing the internet. 


\section{Introduction: Why Study the Development of the American Vice Presidency?}

"Gentlemen, I feel great difficulty how to act. I am possessed of two separate powers; the one in esse and the other in posse. I am Vice-President. In this I am nothing, but I may be everything."1

(Vice President John Adams)

The American vice presidency is unique among political and government institutions. The office was referenced rarely at the Federal Convention of 1787, with its inclusion in the proposed United States Constitution certain only in the final days of the proceedings; and it never garnered much enthusiasm from the Convention delegates, or when the document was later ratified state-by-state. However, today the vice presidency is a different institution than the one designed by the Framers. And yet, the fundamental structure of the vice-presidential institution, in conjunction with the responsibilities sanctioned in the Constitution for whoever held the office, remain intact, as when originally established.

If the vice presidency continues to be, in form, essentially the same institution the Framers envisioned--although, admittedly, it is a stretch to suggest that, when it came to the vice presidency, the Framers had a vision for the institution--then how is it a changed institution today? And what specific dynamics are responsible for transforming the vice presidency?

In order to answer the foregoing questions, it is important to first acknowledge this point: the American vice presidency has not been a dormant institution. At the same time, the development of the vice presidency since its inception should not be described as a matter of institutional evolution. Instead, the vice presidency is an institution that has 
been affected by specific institutional markers which have then incrementally enhanced its development. As such, the following narrative traces the arc of development of the vice presidency, beginning with its inception; and then, by isolating the institutional markers that have facilitated the development of the institution. These institutional markers include augmentation by precedent, statute, and constitutional amendment; increases in the resources made available to the institution; the addition of symbolic institutional identifiers; and the gradual accumulation of policy portfolios vice presidents are expected to take on. In the aggregate, institutional markers such as those just listed, have helped to make the vice presidency a formidable institution; and the individual serving in the office, an influential figure in the executive government.

Despite the preceding points, of all the areas of politics and government subject to research and analysis, the vice presidency continues to be among the most overlooked. And yet gaining an understanding of the American vice presidency is necessary for a number of reasons, particularly in light of the developed, modern incarnation of the institution. As will become evident, the vice presidency matters foremost because of the presidency. Although there are several dynamics that make this so, the most salient reason for why the vice presidency matters, in relation to the presidency, becomes apparent when reviewing the presidency in aggregate.

As of this writing, forty-three individuals have served as president. Grover Cleveland holds the distinction of being the sole individual to win nonconsecutive presidential terms and so Cleveland is counted as the twenty-second, as well as the twenty-fourth president. Of the forty-three individuals to have been president, fourteen were first the vice president of the United States. Of the fourteen, eight ascended to the 
first office of the land because of the death of the incumbent president, whereas just one vice president arrived in the Oval Office because of the resignation of the president. In addition, five other presidents served as vice president prior to winning a term as president in their own right: John Adams, Thomas Jefferson, Martin Van Buren, Richard Nixon and George H.W. Bush.

Attaining the presidency without the benefit of succession has not been a guarantee of two terms in office, however; for after winning the presidency, only Jefferson and Nixon were elected to a second term, and because Nixon resigned in the midst of the sixth year of his presidency, just Jefferson fulfilled his second term as president. What is more, of the nine vice presidents to succeed to the presidency, only four--Theodore Roosevelt, Calvin Coolidge, Harry Truman, and Lyndon Johnson--were successful in earning the presidential nomination of their party, and then winning their own term in office.

In the latter part of the twentieth century, the vice presidency proved to be one of the better indicators of future presidential nominees. Richard Nixon, Hubert Humphrey, Gerald Ford, Walter Mondale, George H.W. Bush, and Al Gore all served as vice president prior to winning the presidential nomination of their party, either while still in office, or in the case of Mondale, after having been defeated for reelection to the vice presidency. Even Dan Quayle--who in tandem with Spiro Agnew was one of the two most hapless individuals to have served as vice president in the twentieth century--was viewed by some, if only fleetingly, as a prospective candidate for the presidential nomination of the Republican Party. This transitory movement came just four years past Quayle's failure to win a second term as the vice president to George H.W. Bush. And 
then, eight years from the time he had left national office, Quayle again organized a campaign for the presidency; though he eventually opted out of the 2000 presidential preference primaries when it appeared the son of the president he once served would likely prevail and capture the nomination for president. As it stands, modern vice presidents, if presidential succession has not already come into play, are likely to be a future candidate for president, with a reasonable expectation of earning the presidential nomination of their party.

But the likelihood of any vice president ascending to the presidency via succession should not be casually dismissed. In the twentieth century alone, two sitting presidents were assassinated (William McKinley and John Kennedy); two died of natural causes (Warren Harding and Franklin Roosevelt); and one resigned from office (Richard Nixon). Furthermore, there was a concerted attempt to assassinate President Harry Truman by two Puerto Rican nationalists; two attempts were made on the life of President Gerald Ford during his brief tenure; and President Ronald Reagan nearly lost his life when he was hit by a would-be assassin's bullet.

Finally, when it comes to the vice president as potential substitute for the president, presidential inability and determinations of when a president is unable to fulfill their duties must be taken into account. Although the Twenty-fifth Amendment to the Constitution established provisions for managing cases of presidential inability, prior to the ratification of the Twenty-fifth in 1967, there was no constitutional means in place to respond, should circumstances call for it. ${ }^{2}$ Again, in the twentieth century, President Woodrow Wilson was incapacitated by a stroke during his second term in office, which 
by any measure would have called for the temporary, or perhaps permanent, relinquishment of his presidential powers.

Likewise, the argument has been made that President Calvin Coolidge suffered from life-long depression, with the illness becoming acute after his favorite son died from an infection caused by an injury suffered while playing tennis on the White House court. ${ }^{3}$ From the time of his son's death forward, Coolidge's behavior was erratic and he became broadly disengaged in his stewardship of the government for the remainder of his time in office. ${ }^{4}$ Were the Twenty-fifth Amendment in place during the presidency of either Wilson or Coolidge, their vice presidents--Thomas Marshall and Charles Dawes, respectively--most likely would have assumed "the powers and duties of the office as Acting President."

Irrespective of the number of times vice presidents have moved up to the presidency; and regardless of the specific circumstances dictating the ascension of the fourteen presidents who were first vice president; the vice presidency, as an institution, has consistently been derided and discounted. Emblematic of the broad disregard for the vice presidency was the 180 years which elapsed before any mechanism was established for replacing the vice president, should the vice president succeed to the presidency, resign from office, or die. Because of this oversight, and again, before the ratification of the Twenty-fifth Amendment, which finally established a constitutional means for filling vacancies in the vice presidency, the office remained unoccupied on a number of occasions for well over three years. And in three instances--after John Tyler and Andrew Johnson succeeded to the presidency; and when Vice President William King died within weeks of being sworn in to office--the nation went without a sitting vice president for 
nearly four years.

What the preceding adds up to is this: the vice presidency has been left vacant eighteen times, for a combined total of almost thirty-eight years. The sheer number of days, months, and years the office was unoccupied, as represented by the data in Table 1.1 , is sobering. And while the Congress has periodically addressed succession and the need to manage a possible double-vacancy in the two nationally elected executive offices, the impression of an expendable vice-presidential institution is plain.

\section{Table 1.1}

\section{Vacancies in the Vice Presidency}

\begin{tabular}{|c|c|c|c|c|c|c|}
\hline \multirow[t]{2}{*}{$\underline{\text { Vice President }}$} & \multirow[t]{2}{*}{ Term } & \multirow[t]{2}{*}{ Cause of Vacancy } & \multirow[t]{2}{*}{ Date of Vacancy } & \multicolumn{3}{|c|}{ Duration of Vacancy } \\
\hline & & & & Year & Months & Days \\
\hline George Clinton & $1809-1813$ & Death & $4 / 20 / 1812$ & 0 & 10 & 12 \\
\hline Elbridge Gerry & $1813-1817$ & Death & $11 / 23 / 1814$ & 2 & 3 & 9 \\
\hline John Calhoun & $1829-1833$ & Resigned & $12 / 28 / 1832$ & 0 & 2 & 4 \\
\hline John Tyler & $1841-1845$ & Succession & $4 / 4 / 1841$ & 3 & 11 & 0 \\
\hline Millard Fillmore & $1849-1853$ & Succession & $7 / 9 / 1850$ & 2 & 7 & 23 \\
\hline William King & $1853-1857$ & Death & $4 / 18 / 1853$ & 3 & 10 & 14 \\
\hline Andrew Johnson & $1865-1869$ & Succession & $4 / 15 / 1865$ & 3 & 10 & 17 \\
\hline Henry Wilson & $1873-1877$ & Death & $11 / 22 / 1875$ & 1 & 3 & 10 \\
\hline Chester Arthur & $1881-1885$ & Succession & $9 / 19 / 1881$ & 3 & 5 & 13 \\
\hline Thomas Hendricks & $1885-1889$ & Death & $11 / 25 / 1885$ & 3 & 3 & 11 \\
\hline Garrett Hobart & 1897-1901 & Death & $11 / 21 / 1899$ & 1 & 3 & 11 \\
\hline Theodore Roosevelt & $1901-1905$ & Succession & 9/14/1901 & 3 & 5 & 18 \\
\hline James Sherman & 1909-1913 & Death & 10/30/1912 & 0 & 4 & 5 \\
\hline Calvin Coolidge & 1921-1925 & Succession & $8 / 2 / 1923$ & 1 & 7 & 2 \\
\hline Harry Truman & 1945-1949 & Succession & 4/12/1945 & 3 & 9 & 8 \\
\hline Lyndon Johnson & $1961-1965$ & Succession & $11 / 22 / 1963$ & 1 & 1 & 28 \\
\hline Spiro Agnew & 1973-1977 & Resigned & $10 / 10 / 1973$ & 0 & 1 & 26 \\
\hline Gerald Ford & 1973-1977 & Succession & 8/9/1974 & 0 & 4 & 8 \\
\hline
\end{tabular}

The notion that more than one of every three presidents first served as the vice president presumably would have prompted numerous assessments of the American vice presidency--past, present and future. However, the paucity of research and literature devoted exclusively to the vice presidency is disquieting. Granted, over the years there 
have been attempts at assessing specifics of the vice presidency, but generally such inquiries have been negligible, at best, and typically are dismissive in tone.

For instance, at the ninth annual meeting of the American Political Science Association, held in 1912, H.B. Learned delivered an address titled "Some Aspects of the Vice-Presidency." ${ }^{6}$ In his remarks, Learned briefly reviewed the historical disregard for the vice presidency, in conjunction with a condensed evaluation of the institutional attributes of the office. Although he emphasized the necessity of having a vice president in place for succession to the presidency, he also casually concurred with the broad dismissal of the office and of those who have held it. In this vein, Learned asserted that there is an assumption, that the vice-presidency has sheltered a collection of mediocrities, men at any rate far below presidential dimensions. This sort of blanket criticism is not easy to disprove...It is easy to recall the Presidents and so very easy, on the other hand, to forget the vice-presidents. There have been men of small distinction and little ability in the vice-presidency. ${ }^{7}$

Academic considerations of the vice presidency arrived sporadically throughout the twentieth century, whether by journal articles or scholarly books. With the implosion of the Nixon presidency, which was preceded by an abrupt ending to the Agnew vice presidency, there appeared to be renewed interest in the executive officers of the nation, particularly the vice president. At that time, Hubert Humphrey, who had already served four years as vice president, noted the second office had "long [been] an ignored or belittled American political institution, [but] has in recent years received more and more 
attention from political scientists, politicians and all the American people." ${ }^{8}$ This made sense with the Nixon administration being the first, and thus far only, in American history to result in the resignation of the vice president, as well as the president. The outcome of Spiro Agnew resigning from the vice presidency; followed closely by Richard Nixon's exit from the White House, was the use--twice within thirteen months--of the constitutional directive for replacing the vice president found in the Twenty-fifth Amendment.

The significance of the Twenty-fifth Amendment to the institutional development of the vice presidency is detailed in the pages to follow, yet before moving forward, the preceding point on the scant time to elapse between replacing two vice presidents demands emphasis. The adoption of the Twenty-fifth Amendment, just six years before it was first put into practice, proved timely; and with the resignation of President Nixon, the amendment prevented the spectacle which might have transpired if Speaker of the House Carl Albert had been moved up to the presidency, per the direction of the Presidential Succession Act of 1947. ${ }^{9}$ Even if Albert might have adequately handled the rigors of the presidency, he was a Democratic congressman from Oklahoma, representing a rural district with a constituency that was far from a demographic microcosm of the nation. This matters because not only were Nixon and Agnew Republicans, but their ticket was overwhelmingly reelected in 1972; Albert's capture of the presidency in this way would have, in effect, nullified "the votes of the 47 million Americans who had cast their ballots for Richard Nixon." ${ }^{10}$ Hence, despite the joint Nixon-Agnew scandals, and because the Twenty-fifth Amendment was in place, continuity in government was achieved and a potential crisis in confidence in the American political system was averted. 
From that era, some notable scholarly studies emerged, including an assortment of journal articles from political scientist Marie Natoli. Natoli focused on various aspects of a smattering of different vice presidents and their respective tenures; though occasionally she ventured into broad considerations related to the institution, such as the Twenty-fifth Amendment and whether or not the position of vice president should be abolished. ${ }^{11}$ In all, though there was certainly value in her work, Natoli generally offered cursory evaluations of the topics she addressed.

Besides the scattered works of Natoli, two useful studies came out around the same time the bulk of Natoli's writings were published: Joel Goldstein's The Modern American Vice Presidency: The Transformation of a Political Institution; and Paul Light's Vice-Presidential Power: Advice and Influence in the White House. Both texts appeared in the early 1980s, and each provides a perfunctory historical context for looking at their respective areas of interest; but neither text devotes much attention to the accumulative institutional markers that have helped to shape the modern vice presidency. As such, the main emphasis of the Goldstein book is on gauging what variables underlie the selection of vice-presidential nominees, and their subsequent role in the campaign; and the primary focus of the Light text is the vice presidencies of Nelson Rockefeller and Walter Mondale, and measurements of the influence either man had on the presidents and administrations they served.

One of the rare treatments of the vice presidency to come out in the 1990s was At the President's Side: The Vice Presidency in the Twentieth Century. ${ }^{12}$ As the title indicates, the text concentrated on a specific timeframe and therefore it failed to address any institutionalizing attributes of the vice presidency prior to 1900. For that matter, 
though worthwhile, At the President's Side lacked a cohesive theme and thus does not provide an inclusive portrait of the vice-presidential institution; offering instead a collection of sketches of individual vice presidents. Ultimately, what plagues studies of the vice presidency produced in the 1980s, up to the mid-1990s, is the inescapable absence of any consideration of two of the most influential and significant vicepresidential tenures to date--those of $\mathrm{Al}$ Gore and Dick Cheney.

In the first decade of the twenty-first century, there was a modest increase in research on the vice presidency. Still, much of that academic work was narrow in scope, and focused on precise areas of interest, such as the dynamics of selecting vicepresidential nominees; polling on vice-presidential favorability and approval; and the isolation and assessment of specific policy portfolios particular vice presidents were assigned. ${ }^{13}$ Though the preceding topics of study were examples of individual contributions to academic journals, the limited range of inquiry on the vice presidency has not been the sole province of periodicals, as book length treatments relating to the vice presidency are fairly uncommon, as well.

Across the board, what have been lacking are concerted evaluations of the expanded vice-presidential institution. Put another way: while there has been extensive research into the development of political institutions; and the appreciable growth of the presidency has given rise to an unrivaled body of academic inquiry; studies of the vice presidency as a political institution are, for the most part, nonexistent; instead, as noted previously, distinct spheres of activity by vice presidents typify studies of the vice presidency. For example, one text came out in 2009 which was devoted entirely to the vice president's role in foreign policy; nonetheless, it failed to include the contributions 
of several vice presidents prior to the forty-second vice president, Walter Mondale. ${ }^{14}$ Without question such an approach has merit, yet it is plainly not as inclusive as it might be.

The development of a foreign policy portfolio for the vice president is not prominently featured here, but at this juncture another mischaracterization perpetuated by the aforementioned text should be pointed out. Even if many of the author's conclusions, with regard to the five vice presidents under review, might be sound, the description of the vice presidency as "semi-institutionalized" is a flawed categorization. ${ }^{15}$ Frankly, at this point in the history of the institution, arguing the American vice presidency is in some way incomplete underestimates the actual state of the institution.

Ultimately, by examining how and why the American vice presidency was established; and by delineating the institutional markers that have contributed to the present locus of the modern institution--all of which is underscored by anecdotal evidence--it becomes clear the vice presidency is a political institution worthy of further examination. And because the vice presidency has always stood so closely beside the presidency, understanding the former institution is as important as understanding the latter. 


\section{The Establishment of the American Vice Presidency}

"The only role the Constitution assigns the vice president is to preside over the Senate and break a tie when necessary. In a strange way, since the vice presidents were in both branches, they historically had been treated as though they were in neither."16 (Vice President Walter Mondale)

In 1908, Woodrow Wilson's influential text, Constitutional Government in the United States, was published. In that book, Wilson had this to say about institutions:

We sometimes attach a very artificial significance to the word 'institution.' Speaking in the terms of history, and particularly of political history, an institution is merely an established practice, an habitual method of dealing with the circumstances of life or the business of government. There may be firmly established institutions of which the law knows nothing. ${ }^{17}$

By Wilson's criteria, the American vice presidency is certainly an institution; it may have been established as a hollow institution, particularly when compared to other institutions of government defined in the United States Constitution, but it is an institution, nonetheless. But it is the story of how the vice presidency was established that makes it a compelling study; for no other institution in the American system was seen as such a superfluous addition to the Constitution; nor was any such officer as the vice president so widely unwanted.

The office of the vice president, when it was eventually included in the Constitution, was remarkable among the institutions of the United States government in that it comprised just a single officer. Unlike the multiple members of Congress or the 
group of Supreme Court justices, or even the president--an officer with the power to make scores of appointments to the federal government, and at the apex of a single branch of government--the vice presidency was instituted as an office devoid of peers, authority, and given minimal responsibilities. Even in terms of responsibilities: the vice president could easily turn those over to the president pro tempore of the Senate, take leave of the Capitol building, and hardly be missed. Indeed, at one point when Congress was trying to settle on salaries for the president and vice president, the idea was put forward to pay the vice president "only on a per diem basis." 18

It is therefore the structure of the vice-presidential institution that makes it distinctive among institutions of the American government. And in some fashion, the vice presidency could be judged a separate, stand-alone institution. What undermines this depiction, however, is the vice presidency is fused with both the executive and the legislative branches--to the former by way of national elections, and to the latter because of the constitutional provision positioning the vice president squarely in the Senate in the presiding officer's chair.

So why was the vice presidency established? Apparently delegates to the Federal Convention of 1787 were in no hurry to create the office. Debate and discussion on a variety of proposals unfolded for over two months at the Convention before the prospect of establishing such an office was broached by delegates, and then solely in reference to organizing the election of the president. ${ }^{19}$ As it was, the presidency was of the most concern to the delegates. More specifically, deciding on a system for electing the president at times stalled the progress of the proceedings. It was this sticking point that led one historian to suggest that irrespective of any other "difficulties...encountered..., 
they paled into insignificance in comparison with the problem...of determining a satisfactory method of electing the executive...The difficulty now had become greater because the powers of the executive had been enlarged." 20

Curiously, an office resembling what became the vice presidency would emerge, in part, as the outline for electing a single, chief executive was taking shape. For it was in the course of discussing proposals for how best to select the president that a consensus eventually emerged that selection should not be the responsibility of the nation's legislative branch; instead, the outcome of contests for the presidency should be determined by a vote of the people. However, a Convention delegate from North Carolina, Hugh Williamson, argued that popular election of the president worked against the least populated states and so "each man should vote for" three candidates on the assumption that one vote would be cast for a candidate from their own state, with the other two votes split between "a small [state and] ...a large one."21

In response to Williamson's proposal, another delegate, Gouverneur Morris of Pennsylvania, offered a slight variation on voting for three individuals for president, with "an amendment that each man should vote for two persons one of whom at least should not be of his own State." ${ }^{22}$ To this, James Madison, the invaluable chronicler of the proceedings, recorded the sole "objection which occurred was that each Citizen after having given his vote for his favorite fellow Citizen, would throw away his second on some obscure Citizen of another State, in order to ensure the object of his first choice." ${ }^{23}$ As it turned out, Madison's reference to throwing away a vote was an apt turn of phrase; for ultimately, in the completed Constitution, the recipient of the most "second" votes for president was awarded the vice presidency. 
Later, when it had been settled that there would be a vice president elected with a president, not all the delegates were satisfied. Among those who found the addition of the second office unnecessary was Hugh Williamson of North Carolina. Williamson dismissively summarized the opinion of many at the Convention when, according to Madison, he "observed that such an officer as vice-President was not wanted. He was introduced only for the sake of a valuable mode of election which required two to be chosen at the same time." 24

From the start, every development of the vice presidency has been linked to the presidency. Moreover, apart from those times when the institution has been addressed or altered in the Constitution, all augmentation of the vice-presidential institution has been initiated and facilitated by specific presidents. Even with respect to the vice president in the Constitution: on the two occasions when constitutional amendments directly affected the vice presidency--those being the Twelfth and the Twenty Fifth Amendments--the incumbent president at the time, Thomas Jefferson and Lyndon Johnson, respectively, was an advocate for the amendment.

Jefferson and Johnson both had a connection to the specific amendments, in that each was linked with what initially necessitated the amendments. The Twelfth and Twenty-fifth amendments are focused on in the third and seventh chapters of this narrative; however, a brief summation of what necessitated the amendments is worthwhile at this stage. Due to the system in place for the first four presidential elections--and the indefinite nature of casting two votes for president, with the vice president being the runner-up for the presidency--Thomas Jefferson nearly had the presidency taken from him by his acknowledged running mate in 1800, Aaron Burr. ${ }^{25}$ 
Although Burr did end up serving as Jefferson's vice president, an uneasiness and distrust colored their relations from that time forward. Jefferson pushed for the Twelfth Amendment in large part because he wanted to ensure a candidate intended for the vice presidency--as was Burr--did not land in the presidency, instead. And so, after the ratification of the Twelfth Amendment, votes cast for presidential and vice-presidential candidates were unmistakably demarcated.

In Lyndon Johnson's case, while he encouraged the creation and adoption of the Twenty-fifth Amendment when he was president, it was because he came to the office from the vice presidency that he was motivated to do something about presidential inability and filling vacancies in the vice presidency. Having succeeded to the presidency upon the assassination of President John Kennedy, Johnson could appreciate the necessity of having a ready successor, should something happen to him while he held office. Because there was no constitutional mechanism for replacing the vice president prior to the ratification of the Twenty-fifth Amendment, Johnson served one year, one month, and twenty-eight days without a vice president. Although Johnson was eventually elected to his own term, and with his own vice president, Hubert Humphrey, the Twenty-fifth Amendment was not ratified until 1967, two years after Humphrey took office.

Because the vice presidency is inexorably linked to the presidency, then it makes sense the mechanics for electing the president are germane to the vice president. For that reason, the original method of selection for the president and the vice president is fixed in the Constitution in the following, straightforward manner:

The Electors shall meet in their respective States, and vote by Ballot for two Persons, of whom one at least shall not be an Inhabitant of the same State with 
themselves....The Person having the greatest Number of Votes shall be the President...In every Case, after the Choice of the President, the Person having the greatest Number of Votes of the Electors shall be the Vice President. ${ }^{26}$

The ramifications of the above passage on the vice presidency were significant. To start, by constitutional directive, the president and the vice president were expected to hail from different regions of the United States. Having presidential and vice-presidential candidates representative of alternate parts of the country would prove to be a balancing variable that, first, political parties employed; and then later, when the presidential nominees of the political parties began to select their running mates, has oftentimes been a central factor in the nominee selection process. ${ }^{27}$

Furthermore, in directing presidential electors to cast one ballot for a candidate of another state, electors from any single state were unable to monopolize what continue to be the only two nationally elected offices in the American system. Besides, casting two votes for president increased the likelihood, assuming there were more than two candidates in the running, that at least one candidate an elector preferred, ended up either president or vice president. To this point, Alexander Hamilton promoted the idea of casting two votes for president; his argument was it would "establish him in the esteem and confidence of the whole Union, or of so considerable a portion of it as would be necessary to make him a successful candidate for the distinguished office of the President of the United States. ${ }^{28}$

What is sometimes overlooked, however, is that by casting two votes for president, there was a good chance the defeated candidate for president, and therefore 
winner of the vice presidency, was an individual with talents equal to the individual who had bested them. ${ }^{29}$ Naturally, the downside to this rationale is that it is quite a stretch to count on a field of presidential contenders to all be quality candidates, and possessing great capabilities. Indeed, it is a challenge to even reach consensus on what might be considered an appropriate means for gauging, let alone what constitutes, high caliber individuals suited for the presidency.

The most significant outcome from casting two electoral votes for president was the candidate who landed in the vice presidency was the certified loser of the presidential contest. Although it might seem an innocuous outcome, it was an outcome that would inform perceptions of the vice presidency, and of those who held the office, for years to come. It does not matter that just three individuals landed in the vice presidency as a result of this electoral method, before it was reformed; nor did it make a difference in the long term if the three--John Adams, Thomas Jefferson, and Aaron Burr--were each remarkable in their own way. Quite simply, coming in second place in the presidential election may have given the vice presidency an occupant, but it also undeniably marked the institution as the lesser of the two nationally elected executive offices; and likewise indicated the holder of the second office in the land was inferior to the winner of the first office.

\section{Attaching the Vice President to the United States Senate}

As noted previously: the shadow of what became the vice presidency was first apparent when delegates to the Federal Convention of 1787 were deciding on how to choose the nation's chief executive. Yet it was not enough to create a post in the government devoid of functions; to stand merely as a consolation prize for the second 
place finisher in the presidential contest. From the labors of the Federal Convention, in particular the deliberations on competing proposals for the form the new government would assume, the position of vice president was established in Article I of the Constitution, transparently attached to the legislative branch.

Reviewing what debate there was on adding the vice president to the Constitution, inside as well as outside of the Federal Convention, reveals indifference, as well as opposition toward such an officer. There was, however, one particularly persuasive advocate for including the position of vice president in the constitutional arrangement: Alexander Hamilton. From the outset, it was Hamilton who advanced the notion that there should be an office resembling what became the vice presidency.

On June 18, 1787, Hamilton published his preferred scheme for the impending, revised American government in a document he titled plainly: "Plan of Government."30 According to Hamilton, "Supreme Executive authority of the United States [was] to be vested in a governor to be elected to serve during good behaviour."31 "Governor" was the title Hamilton applied to the head of the executive branch, presumably in acknowledgement of the chief executives of the state governments operating at that time. Clearly Hamilton was an advocate for the addition of an executive to the national government, but he was also obviously aware of the need to prepare for any contingencies that might threaten the viability and continuity of the national executive.

For example, Hamilton was prepared for the vagaries of electoral politics when he recommended the election of the executive "be made by Electors chosen by electors chosen by the people in the election districts aforesaid or by electors chosen for that purpose by the respective legislatures--provided that if an election be not made within a 
limited time the President of the Senate shall be the Governor." 32 What is noteworthy about the preceding lines from Hamilton's "Plan of Government" is that in providing a solution for filling the executive in the event of a delayed or possibly disrupted election, he was covertly making the case for a secondary, or backup, executive officer to be available, if the need for one should arise.

Hamilton took the idea of providing for a standby executive even further when he interjected, though not in these exact words, the notion of having a ready successor to the chief executive. Although presidential succession is specifically addressed later, it merits a brief mention at this point that some have argued the vice presidency was not instituted to "solve the problem of succession." ${ }^{33}$ While there is certainly validity in such a claim, preparing for probable succession scenarios was categorically on Hamilton's mind when he proposed: "On the death resignation or removal of the Governor his authorities [are] to be exercised by the President of the Senate."34

In sketching an office of the government that was eventually realized in the form of the vice presidency, Alexander Hamilton was not merely acting on some epiphany he had experienced. What Hamilton was doing was taking a state level position--the lieutenant governor--and integrating that officer into the plan for the national government. At that time, ten of the states included the position of lieutenant governor in their system of government, with one state, Pennsylvania, actually giving the lieutenant governor the title of "Vice-President.",35

If Hamilton initially failed to designate a proposed national lieutenant governor as the vice president, in every use of that officer advanced in his "Plan of Government," he was explicit on the appropriateness of the president of the Senate taking on those 
functions and responsibilities; and it did not take long before establishing a vicepresidential officer was one of Hamilton's primary objectives, as he strove to assure passage of the Constitution, and thus enhance the presence of the executive in the document. From Hamilton's perspective, the proposed vice president was a suitable officer of the government, analogous to "a Lieutenant-Governor, chosen by the people at large, who presides in the Senate, and is the constitutional substitute for the Governor, in casualties similar to those which would authorize the Vice-President to exercise the authorities and discharge the duties of the President." ${ }^{\prime 36}$

It was in The Federalist papers, specifically essay No. 68, that Hamilton outlined the need to include a vice president in the Constitution; it would be the only formal advocacy for, and defense of, the institution to emerge. To those who argued against instituting the vice presidency, Hamilton responded in this way:

The appointment of an extraordinary person, as Vice-President, has been objected to as superfluous, if not mischievous. It has been alleged, that it would have been preferable to have authorized the Senate to elect out of their own body an officer answering that description. But two considerations seem to justify the ideas of the convention in this respect. One is, that to secure at all times the possibility of a definite resolution of the body, it is necessary that the President should have only a casting vote. And to take the senator of any State from his seat as senator, to place him in that of President of the Senate, would be to exchange, in regard to the State from which he came, a constant for a contingent vote. The other consideration is, that as the Vice-President may occasionally become a substitute for the President, in the supreme executive magistracy, all the reasons which 
recommend the mode of election prescribed for the one, apply with great if not with equal force to the manner of appointing the other. ${ }^{37}$

When Hamilton suggested in The Federalist the necessity of having "the VicePresident...occasionally become a substitute for the President," he was, just as he had in his "Plan of Government," pushing for the vice president, if need be, to take on the duties and responsibilities of the president. Hamilton's proposed use of the vice president in this capcity matched his consistent view to the president of the Senate being the preferred substitute for the president.

By the time The Federalist (No. 68) was published, the Federal Convention had already concluded, and the Constitution was being ratified state-by-state. But making the vice president the successor to the president, whether it be a temporary or permanent substitution, had not gone without objection at the Convention. In building the case for simply using the president of the Senate--a position many of the delegates assumed would come from among the sitting members of the chamber--for an occasional substitute for the president, Gouverneur Morris appeared to mock the idea of a distinct position being created for succession, claiming "the vice president then will be the first heir apparent that ever loved his father. If there should be no vice president, the President of the Senate would be temporary successor, which would amount to the same thing." 38

Although there is no record of why the route Morris suggested failed to carry the day, there is a plausible explanation for why it is better that it did not. When it came to succession, be it temporary or permanent, there was a distinct advantage in preserving continuity in governance. Of course, ensuring continuity in the executive government 
also rested on the assumption the president and vice president were of the same political persuasion. When, in 1796, John Adams defeated Thomas Jefferson for the presidency, and Jefferson wound up vice president to Adams, their partisan differences undermined any notion of a unified executive government. Even though succession prompted by circumstances other than the 1800 presidential election never came to pass when Adams and Jefferson served together, if it had, then control of the executive government would have shifted between opposition political parties.

It would seem, despite the lack of enthusiasm for having a vice president included in the Constitution, and with no readily apparent use for the officer but as a stand-in for the president, the vice president was given the added title of president of the Senate; authorized to preside over the upper chamber of Congress; and given a vote if a tie amongst the members should occur. Yet, in giving the vice president even a limited role in the legislative branch, the dichotomous character of the institution was cast.

By virtue of the vice president being elected at the same time and in the same manner as the president, then presumably the vice president could be counted as part of the executive branch. Likewise, the expectation for the vice president to, on occasion, assume the responsibilities of the president, furthered the idea of the vice president as one of two national executives. And yet, nowhere in the Constitution was a single executive duty or function delegated to the vice president. Even the implementation of succession may not be construed as the vice president acting as an executive, since the instant any vice president succeeds to the presidency, their vice presidency is over and they have become the chief executive.

Trying to determine exactly which branch of the government the vice president 
genuinely belonged with was problematic. Even Woodrow Wilson, who devoted a fair share of his academic career to the deconstruction of constitutions and systems of government, was perplexed by the vice presidency. Wilson depicted the institution and the ambiguity surrounding it in this way:

It would, doubtless, be considered quite improper to omit from an essay on the Senate, all mention of the Senate's president; and yet there is very little to be said about the Vice-President of the United States...Apparently he is not, strictly speaking, a part of the legislature,--he is clearly not a member,--yet neither is he an officer of the executive. It is one of the remarkable things about him, that it is hard to find in sketching the government any proper place to discuss him. He comes in most naturally along with the Senate to which he is tacked; but he... is simply a judicial officer set to moderate the proceedings of an assembly whose rules he has had no voice in framing and can have no voice in changing. His official stature is not to be compared with that of the Speaker of the House of Representatives. So long as he is Vice-President, he is inseparable officially from the Senate; his importance consists in the fact that he may cease to be VicePresident. His chief dignity, next to presiding over the Senate, lies in the circumstance that he is awaiting the death or disability of the President. ${ }^{39}$

Wilson's uncertainty about the status of the vice president was well-founded. Even though the office was firmly established in the Constitution, it seemed to be an institution barely anchored to the government. As it is, Wilson's brief consideration of the office of vice president failed to settle any of the questions it raised. So why, when 
the position of vice president was instituted, was the office attached to the Senate? To start, by pulling from outside the Senate membership for a presiding officer, no state was expected to give up one of its senators to preside, and therefore lose one of its two votes in the chamber; it was this deference to the states for which Alexander Hamilton was arguing in the earlier selection from The Federalist.

If preserving the right of every state to have two consistent votes in the Senate was the objective of making the vice president the presiding officer, then there was an unfortunate auxiliary outcome, as well. Again, as was the case for much of the story of the vice presidency, perceptions about the institution, and whomever held the office, colored the standing of the vice president within the government. By placing the vice president in the presiding officer's chair, but deprived of a role in the deliberations of the Senate and with only a limited vote; and in turn, not establishing any tasks for the vice president in the executive branch, the idea quickly took hold of an officer of the government who served without power, and with minimal functions. One delegate to the Federal Convention, Roger Sherman, captured the seeming futility of the vicepresidential institution best when he remarked, "if the vice-President were not to be President of the Senate, he would be without employment."40

Among others, Elbridge Gerry, Govurneur Morris, Edmund Randolph, Hugh Williamson, and George Mason were opposed to the vice president's posting as the presiding officer of the Senate. ${ }^{41}$ Their sentiments were in large part influenced by the matchless character of the institution; for it was, if powerless, the only institution of the impending new government apparently belonging to two of the three branches being proposed. 
So if the vice president was attached to the Senate via the role of presiding officer, in what ways, specifically, was the vice president a part of the executive branch? The design of the Constitution linked the vice president to the executive branch in four distinct ways: first, in order to be eligible for the vice presidency, the potential candidate was expected to match the birth, age, and residency requirements set for those seeking the presidency. Second, the vice president would be chosen at the same time and in the same manner as the president. Third, though the language of the Constitution was far from explicit on this account, the vice president was the designated substitute for the president, when necessary. And finally, the vice president was included, in Article II of the Constitution--literally in the company of the nation's chief executive. Because of the preceding four points, it was a fair assumption the vice president should be included in the executive branch.

Because Article II of the Constitution transparently integrated the vice president into the executive, while Article I placed the vice president in the Senate, there were some who interpreted this as an unwelcome intrusion of the executive into the legislative sphere. For example, George Mason, "thought the office of vice-President an encroachment on the rights of the Senate; and that it mixed too much the Legislative \& Executive, which as well as the Judiciary departments, ought to be kept as separate as possible." ${ }^{42}$ Similarly, an indignant Elbridge Gerry, who was unequivocally opposed to the addition of the vice president to the new government, argued if the vice president was to oversee the proceedings of the Senate, then the delegates "might as well put the President himself at head of the Legislature. The close intimacy that must subsist between the President \& vice-president makes it absolutely improper." ${ }^{, 43}$ 
As it was, Gerry and Mason, along with Edmund Randolph, were the only three participants at the Convention to refuse to sign the finished document. In an ironic twist, Gerry later became the nation's fifth vice president. And though he was never close to the president he served, Gerry's worries about the vice president's presence in the Senate, tied with his claims of the "close intimacy" that surely must prevail in the president-tovice president arrangement, would prove prophetic. Unknowingly, Gerry had described what would become the nature of relations between modern presidents and their seconds. 


\section{Institutional Development by Constitutional Directive: The Twelfth Amendment}

"The amendment will make the Constitution worse than it now is, believing as I do that it may bring a man into the Presidency, not contemplated by the people for that office."44

(Representative James Elliot)

The American vice presidency came to be by way of its inclusion in the Constitution of the United States. Still, apart from its inception, the vice presidency has been directly affected by constitutional amendment in just two instances: first, in 1804, with the addition of the Twelfth Amendment; and then, 163 years later, when the Twenty-fifth Amendment was ratified in 1967. Each of the preceding amendments modified the vice-presidential institution with respect to the selection of the vice president; and both amendments preserved the constitutional arrangement whereby the president and the vice president are irrefutably linked. In the process, the ratification of the Twelfth and Twenty-fifth Amendments, though in decidedly different ways, helped to reform, as well as to reinforce, attitudes about the vice presidency and vice presidents. Impetus for Altering the Way the President and Vice President Were Elected

The process put in place at the Federal Convention of 1787 for electing the president and vice president worked perfectly for the first two presidential elections. By the third presidential election--held in 1796--the way the president and vice president were chosen revealed a flawed system. And by March of 1801, when the presidential election of 1800 was finally decided, the process for choosing the president and vice president had unraveled, and the impetus for change had arrived.

Compelling the need for change in the way in which the president and vice president were elected was the emergence of political parties. More importantly, the 
intrigues of specific political leaders, acting on behalf of their party's interests, would mark the beginning of candidates ostensibly running for vice president. But political parties as they exist today were not to be found at the time the vice presidency was instituted; nor did they overtly influence the first two presidential contests. However, after John Adams had served for eight years as the nation's first vice president; and then when he became the first of many vice presidents to try to move from the vice presidency to the presidency, organized political parties were swiftly becoming fixtures on the burgeoning American political scene.

Although political parties, per se, are not the topic of this project, the importance of political parties to the vice presidency should not be overlooked and warrant inclusion in any consideration of the development of the vice-presidential institution. For that matter, political party elites, and then later the presidential nominees of the two major political parties in the United States, have been responsible for selecting and nominating vice-presidential candidates. Moreover, because vice-presidential candidates are not voted for apart from the presidential candidates, it is reasonable to suggest political parties and modern presidential nominees have been the arbiters of who ultimately will be the vice president--and therefore possibly president. For these reasons, political parties and presidential nominees have been critical to the development of the vice presidency throughout the history of the institution and, in the case of modern presidential nominees, continue to determine the occupant of the office.

The political parties of the late eighteenth century were a far cry from what they soon became, but the idea of associations of the politically active was far from novel. James Madison, for one, had advised delegates to the Federal Convention to be wary of 
the mischief of factions; describing a faction as "a number of citizens, whether amounting to a majority or a minority of the whole, who are united and actuated by some common impulse of passion, or of interest, adverse to the rights of other citizens, or to the permanent and aggregate interests of the community." ${ }^{45}$ Madison, irrespective of the ominous opinion he held for factions, and despite the havoc he prophesized factions might incite within the broader political process, had apparently accepted "that the causes of faction cannot be removed, and that relief is only to be sought in the means of controlling its effects."

Similarly, George Washington apparently felt the need to warn members of Congress about the machinations of political parties. Offered as a parting shot upon his retirement, Washington claimed that those "of a party...may now and then answer popular ends, [but] they are likely, in the course of time and things, to become potent engines, by which cunning, ambitious, and unprincipled men will be enabled to subvert the Power of the People, and to usurp for themselves the reins of Government; destroying afterwards the very engines which have lifted them to unjust dominion."47

It was the election of 1796 that set the stage for the first transparent manifestation of political parties, and the ensuing gamesmanship that has since colored presidential politics. As continues to be the case in the United States today, two distinct political associations dominated politics in 1796: one group, commonly denoted as the Federalists; the other, alternately designated as the Democratic-Republicans or Jeffersonian Republicans. ${ }^{48}$ Initially the Federalists had emerged as a loosely connected group advocating for the adoption of the Constitution; yet by 1796, the incumbent vice president, John Adams, was the acknowledged head of a more formal, recognizable party 
of Federalists. Although Adams was the accepted leader of the Federalists, it should be noted that his domination of the group was not complete, as Alexander Hamilton was certainly recognized as a rival leader within the party. As it turned out, the Federalists were not long on the political scene, with their perceptible demise starting with the election of 1800 and almost complete at the finish of the election of 1804.

As the Federalists weakened and then, in a sense, disbanded, a number of other minor political factions appeared and disappeared; however, all of these groups failed to coalesce into permanent associations. Though the Whigs--a conglomeration of opponents of the policies of President Andrew Jackson--did succeed in intermittently electing presidents and vice presidents; specifically, the teams of William Henry Harrison and John Tyler, and Zachary Taylor and Millard Fillmore. Curiously, both elected Whig vice presidents succeeded to the presidency upon the death of the elected Whig presidents, thus making four Whig presidents in all. It would seem that the deaths of Harrison and Taylor presaged what became of an organized Whig element in American politics.

Conversely, the Democratic-Republicans arose from a fellowship of politicos who adhered primarily to the words and deeds of Thomas Jefferson; it was an association that, after 1796, achieved greater success than the Federalists. Eventually most DemocraticRepublicans drifted toward Andrew Jackson as their leader; condensed their name to simply the Democratic Party; and effectively dominated the national government for all but eight of the next thirty-two years.

In effect, Jackson's Democrats were only occasionally challenged for control of the national government, and not seriously until the election of 1860 . In that year, the victors came in the form of the Republican Party--a coalition of party regulars, most of 
who had identified with the National Republican Whig Party, just four years prior. By 1860, many of the same National Republican Whigs were instead known as Republicans, and from their nominating convention they delivered Abraham Lincoln and Hannibal Hamlin to run for president and vice president, respectively. Lincoln, in 1856, had briefly been considered for the vice-presidential nomination on the first Republican ticket, but was, perhaps fortuitously, passed over by the new party.

But in 1796, there were not yet nominating conventions; instead, the political parties chose their candidates for president, for the first time, by means of the congressional caucus. ${ }^{49}$ In that year, the two party caucuses were merely perfunctory exercises, for there was no doubt the Democratic-Republicans would nominate President Washington's former secretary of state, Thomas Jefferson, for president; and the Federalists were sure to nominate Vice President Adams to oppose Jefferson. ${ }^{50}$ Both parties also indicated a preference for vice president--at that time, the runner-up in the presidential contest--with Aaron Burr the accepted second to Jefferson; and Thomas Pinckney, to stand with Adams.

Of the four principal candidates, Aaron Burr would prove most like a vicepresidential candidate in a modern presidential campaign. Burr's behavior was suggestive of future vice-presidential candidates, in that he campaigned vigorously for the Democratic-Republican team for several weeks. ${ }^{51}$ Burr's activism was in stark contrast to the behavior of the other three principal candidates, as Jefferson, Adams, and Pinckney largely avoided overt campaigning. ${ }^{52}$ Burr's atypical campaigning did not escape notice and caused unease within his own party, leading many to think his real objective was winning the presidency, not the vice presidency; it was an accusation against Burr that 
was repeated even more forcefully during the campaign for the presidential election of $1800 .^{53}$

In addition to the behavior of the Democratic-Republican candidate intended for the vice presidency, on several counts the election of 1796 may be seen as the precursor to future political party campaign activities. ${ }^{54}$ In no way is this meant to suggest such tactics parallel entirely those of modern campaigns; however, much of what is now commonplace in campaigns and elections was apparent in 1796. Some of the tactics employed were entirely new to the political landscape; some were familiar, but vastly extended by Aaron Burr in the campaign; and all swiftly became staples of American political campaigns from that time forward. Ultimately, Democratic-Republican activists were the more prescient of the two competing groups, as they deliberately cultivated support for their candidates from the people, apparently recognizing the future of presidential elections was perhaps outside of the domain of traditional political elites. ${ }^{55}$

In 1796 sixteen states sent electors to the Electoral College. Of those sixteen states: six chose their electors by popular vote; and the remaining ten states formed their slate of electors by way of their state legislature. As such, in those states choosing electors via the legislature, the political party that dominated the legislature plainly had the edge in elector selection. Adding to the potential for political intrigue was, and still is, this quirk in the design of the Electoral College: electors are in no way required to vote for specific candidates. And it was this procedural loophole that President Washington's secretary of the treasury, Alexander Hamilton, hoped to exploit to his own political satisfaction. 
At some point in 1796, Alexander Hamilton decided to try and propel the accepted Federalist candidate for vice president, Thomas Pinckney, into the presidency. ${ }^{56}$ It apparently did not matter to Hamilton that John Adams was his party's presidential candidate, as Hamilton, a long-time adherent of George Washington, could never entirely accept Adams as the heir apparent to the first president; preferring instead to begrudge Adams, and his place in the Federalist hierarchy. Furthermore, Hamilton's closeness with President Washington had kept him conveniently near the apex of power and influence for many years, making Adams more of an irritant than a threat. But with Washington approaching the threshold of retirement, John Adams seemed a most unlikely conduit to power for Alexander Hamilton. Hamilton understood that his best chance to maintain influence in the capital lay in depriving Vice President Adams of ever becoming President Adams. ${ }^{57}$

Setting what was to become the foundation for practically every future vicepresidential selection, Aaron Burr and Thomas Pinckney were chosen for the electoral advantage each presumably brought to their respective political parties. The attachment of Burr was expected to make the difference for Jefferson in winning New York's highly coveted electors; and in Pinckney, the Federalists hoped to gain the requisite electors from the South. ${ }^{58}$ However, Alexander Hamilton was focused, unlike his Federalist brethren or the opposition Democratic-Republicans, on a less transparent aim than regional ticket-balancing. For Hamilton intended to use the Federalist vice-presidential hopeful in a manner that would be, in the long term, of considerable value to him. Put simply, Hamilton's objective was to divert just enough Federalist electors away from Adams to elevate the proposed Federalist vice-presidential candidate to the presidency. ${ }^{59}$ 
When Hamilton's plotting was uncovered, concerned members of his own party made sure it did not come to fruition, leaving Hamilton's ambitions unfulfilled, and Pinckney no closer to the presidency, nor, as it would turn out, any closer to the vice presidency. ${ }^{60}$

In the end, John Adams prevailed in the Electoral College by earning seventy-one votes to Thomas Jefferson's sixty-eight votes; next was Thomas Pinckney with fifty-nine votes; followed by Aaron Burr's thirty votes, with the remainder of electoral votes scattered among nine other individuals. In the short term, Adams's victory afforded the vice presidency greater cachet, for it set an expectation of the sitting vice president being the logical successor to the president.

The election of Thomas Jefferson to the vice presidency had a further, discernable effect on both the institution, and on the American political psyche. First, Jefferson's ascension to the second highest office in the land, and even his acceptance of the job, added further prestige to a position that Adams initially made credible. And second, Jefferson's success as the leader and candidate of the Democratic-Republicans signaled the transparent arrival of a new and competitive political party; a party poised to contest the Federalist's control of an adolescent American government.

Although the election of 1796 marked the most tangible manifestation of political parties up to that stage in American history, it likewise served as the starting point for deliberately indicating a preference for vice-presidential candidates. But apart from the preceding watershed events, the campaign and election of 1796 was significant for the ensuing additional reasons: it was one in which a candidate meant for the vice presidency campaigned in lieu of the active participation of the presidential candidate; specific individuals were chosen as vice-presidential candidates because of an anticipated 
electoral advantage that might come to the political party from making that choice; and lastly, in 1796 the assumed vice-presidential candidates were the object of considerable interest, and even intrigue, but when the votes were tallied, it was the presidency that mattered most.

The Presidential Election of 1800

Midway through the presidential election year of 1800, America's first two genuine political parties utilized a caucus of their congressional members as the means for nominating candidates for the national executive. Even if the political parties were different in form than they are today, the rudimentary outline of political party machinery was existent in nearly every state, beginning with the election of 1796 , and confirmed during the electoral season of 1800 . The vice president, Thomas Jefferson, was the preferred presidential nominee of Democratic-Republican partisans; and the president, John Adams, was the choice of most Federalists. It was a contest that pitted, again, two of the foremost political figures of the era against one another. Moreover, it was a clash informed by ideological differences that separated the principals; differences underscored by fundamental disparities on how the practices of the government, the presidency, and the vice presidency should transpire. From a historical vantage, the real significance of the election of 1800 lies in its anomalous nature; for never since has the incumbent president run for reelection against the incumbent vice president, as they did that year.

Not surprisingly, a lesser match-up colored the vice-presidential contest. Aaron Burr was once more the acknowledged Democratic-Republican choice for vice president; and this time John Adams would have Thomas Pinckney's brother, the Federalist enthusiast Charles Cotesworth Pinckney, as his intended vice president. Although the 
party nominations were not formalized until after several preliminary state contests, all four men had been the probable contenders for some time; still, there were certain obstacles to overcome before the Democratic-Republican caucus settled on Burr. ${ }^{61}$ And yet, of more significance than any of the nominees to emerge were the compacts the parties made within their respective caucuses. While the compacts were rudimentary--a pledge to cast both electoral votes exclusively for the two, respective nominees of their party--the minimalism of this strategy belied the decided impact it was to have on the outcome of the election. ${ }^{62}$

The election of 1800 brought Aaron Burr to the vice presidency. To better understand the circumstances by which Burr arrived there, it is necessary to briefly revisit the political world of New York at the onset of the nineteenth century. At that time, leadership of New York Democratic-Republicans was under three spheres of influence: future vice president George Clinton and his family; the close-knit Livingston clan; and Aaron Burr and his numerous steadfast followers. ${ }^{63}$ Of the three groups just cited, just one vigorously entered into the fray. Hence, in the prelude to New York's selection of its twelve electors to the Electoral College, the Clinton and the Livingston families acquiesced to Aaron Burr's domination of the process. ${ }^{64}$ The decision by the two clans to restrain themselves in the conduct of the campaign and election had consequences none of them could ever have anticipated.

Burr's efforts began with the construction of a slate of capable and attractive Democratic-Republican candidates for the state legislature. Success in this effort was crucial, as New York's legislature was responsible for selecting the state's twelve presidential electors. As a consequence, the legislature had the power to deliver or to 
deny the partisan composition of electors who then contributed New York's vote to the Electoral College's tally for president and vice president. ${ }^{65}$

More than one biographer has chronicled Burr's innovative tactics in 1800; wherein he organized the drive in New York much like a modern political campaign, exceeding what he had done for the 1796 election. ${ }^{66}$ For example, on top of targeting specific supporters for financial contributions and setting up ward-level committees, Burr compiled an inclusive list of New York City's eligible voters; delineating such details as 'the voter's political preferences, the degree of his zeal in their pursuit, his temperament, his willingness to serve the cause as a volunteer, his financial standing, etc." ${ }^{\circ 7}$ Burr's labors at the local level proved vital to the outcome of a national election.

Of course none of the preceding is meant to imply that Aaron Burr had New York to himself, as Alexander Hamilton, one of the leading Federalists of that state, functioned as Burr's natural counterpart. To be sure, Hamilton was proactive for the Federalist cause; piecing together the legislative slate for his party, and coordinating the electoral ground game in New York City. ${ }^{68}$ Regardless, when all the campaigning was over and the votes were tallied, for Hamilton it had all been for naught. As a tactician, Hamilton proved no match for Burr; he had not sufficiently organized for, nor had he delivered in, New York's preliminary election competition. Therefore, and as a result of Burr's cunning and strategic prowess, Hamilton was prevented from retaining sufficient Federalist control of the state legislature.

In the main, three of the four major candidates in 1800--John Adams, Thomas Jefferson, and Charles C. Pinckney--avoided much in the way of overtly campaigning for the national executive positions. For Adams and Jefferson this meant maintaining 
dignified and, to some extent, removed presidential candidacies. Yet, neither Adams nor Jefferson was entirely idle in the lead-up to the election. In Adams case this meant arranging some well-timed travel, no doubt effectively arousing broader awareness of his candidacy in the upcoming election. ${ }^{69}$ And for Jefferson, a restrained candidacy was defined by profusely writing letters brimming with politics, as well as actively overseeing the written work of others--all of which unmistakably indicated Jefferson was in the race for the presidency. ${ }^{70}$ As to Aaron Burr: in stark contrast with his presumed rival for the vice presidency, Pinckney, Burr kept a comparatively high profile throughout the year, focusing on different regions and states when they came into play. ${ }^{71}$ Unknowingly, Burr was creating an activist role in the campaign that would serve as a prototype for future vice-presidential candidates.

One of the more effective efforts made towards influencing the outcome of the 1800 election came, not from the words or deeds of any of the candidates that year, but instead from the pen of Alexander Hamilton. Hamilton had chosen to write and publish a vicious attack on John Adams that cast a dark pall on his character; it no doubt undermined the Federalist cause broadly, all the while contributing to a further decline in support for Adams, specifically. ${ }^{72}$ As in 1796 , Hamilton knew well that his influence in the next administration was sure to be stymied if Adams or Jefferson won the presidency, but the ascension of either Pinckney brother might have given him the access to power he craved. $^{73}$

When the outline of the electoral vote was pieced together, state-by-state, it appeared the incumbent vice president would likely defeat the incumbent president. The real question then was this: who was to be vice president for the next four years? And 
when, in late December, the Electoral College tally was at last complete, every Democratic-Republican elector had kept their caucus pledge, casting both electoral votes exclusively for their party ticket; whereas, Federalist electors fell short in fully honoring their own comparable vow. As a consequence, the Electoral College voting went as follows: Thomas Jefferson and Aaron Burr each received seventy-three votes for president; John Adams received sixty-five votes; Charles C. Pinckney sixty-four; and John Jay gained one electoral vote--a single vote from the state of Rhode Island that, had it been cast for Jefferson or Burr, could have averted what came next. ${ }^{74}$ Resolving the Election for President and Vice President in 1800

The tie between Jefferson and Burr presented an extraordinary opportunity to settle a presidential election, for the first time, in Congress. To begin with, the Constitution is explicit on the method for resolving those instances when the Electoral College balloting for president results in a tie: members of the House of Representatives are left to decide the outcome with each state delegation having a single vote to cast. Under most circumstances the mechanics for settling the election would proceed in a fairly seamless manner; however, in place to decide the outcome of the election was a House membership composed of a polarized, but decidedly Federalist majority.

Clearly then, the tie vote for president was owned entirely by the opposition political party; hence, the defeated party was poised to select the victors for the offices of president and vice president, from among the opposition candidates. As it stood, the vote of the House of Representatives would determine the winner of the presidency, with the second-place finisher left with the vice presidency. This constitutional edict was complicated even further when the top two contenders for president were members of the 
same political party, but had run for office, presumably, as a team. What is more, the tie between Jefferson and Burr meant that the vice-presidential nominee was unexpectedly a contender for the presidency, thus flipping the intended hierarchy of the ticket.

When the House of Representatives met in early 1801 to decide the fate of the presidency and vice presidency, sixteen state delegations participated. A modest majority of nine states was necessary to win; and yet, there was nothing simple about this particular election, and so the intrigue, accusations, and political maneuvers grew with each vote taken by the House. What ensued were deadlocks, reports of assassination plots, and threats of secession. ${ }^{75}$ In six days, the House voted for president thirty-five times; each time Thomas Jefferson won eight states, Aaron Burr six, with two abstentions.

At some point in the process of choosing the next president, Federalist James Bayard of Delaware, among others, began to seek a compromise for ending the stalemate. But, unlike his Federalist brethren, Bayard had an unusual advantage in the proceedings: being the only House member from Delaware, he was in control of a delegation of one. ${ }^{76}$ Bayard knew, as did every other Federalist in Congress, that a president had to be chosen, sooner or later, and the two alternatives for president were members of the opposition party. What made Bayard finally decide to abstain, which along with other shifts in the voting gave the election to Jefferson, is unclear. But what is certain is the anxiety most Federalist members of Congress maintained about a Jefferson presidency was, in the end, assuaged with the deliverance of Aaron Burr to the vice presidency, instead.

There has long been speculation that Thomas Jefferson agreed to certain Federalist demands, in an effort to obtain the necessary support in the House that would 
allow him to finally move from the vice presidency to the presidency. ${ }^{77}$ It is possible that Federalist members of Congress, when faced with a choice between Jefferson and Aaron Burr, could not reconcile themselves to a president with as questionable a character as Burr was alleged to possess. And perhaps Jefferson was willing to barter with his Federalist foes, so long as he would not have to serve another term as vice president--this time under Burr. Either way, it is quite likely that some covert dealings transpired to tip the election.

To this end, one historian posited that if "Jefferson abandoned any of his original plans, and in that sense bargained away any of his principles to win the office, [it] is extremely unlikely; but when he entered the White House it was after satisfying the Federalists that he and they had come to some kind of understanding." "78 At any rate, Thomas Jefferson's selection as president and Aaron Burr's as vice president was eventually determined by the House of Representatives, and on the thirty-sixth ballot. The final tally stood at ten states for Jefferson, four states for Burr, and two states opting for abstention from the historic electoral contest.

Surely the presidential election of 1800 will be recalled for the anomalous tie between Thomas Jefferson and his running mate Aaron Burr; yet, the election will be remembered equally for the political intrigue that marked the entire contest. Much of the scheming that year can be traced to disgruntled Federalists, particularly Alexander Hamilton. And, as it turns out, it was the scheming of Hamilton and others which laid the groundwork for the demise of the Federalists as an organized political party. Nonetheless, political discord in the Federalist camp did not arise solely from within. When the opportunity presented itself, Burr, for one, did what he could to stoke the internal quarrels 
of the Federalists. ${ }^{79}$ Early on, Burr discerned that if events fell into place he might become the president, instead of the vice president, as was intended.

The complexities to arise in resolving the election of 1800--in stark contrast to the three prior presidential elections--signaled that something was seriously amiss in the method used to select the president and vice president of the United States. As Hamilton presciently observed in 1789: "Every body is aware of that defect in the constitution which renders it possible that the man intended for Vice President may in fact turn up President." 80

The Twelfth Amendment

In the immediate aftermath of the election of 1800, Aaron Burr's willingness to usurp Thomas Jefferson's claim on the presidency was the impetus for altering how the president and vice president were selected. Being a leading political figure of the era, Burr's complacency in tying the presidential nominee of his own party in the vote of the Electoral College was troubling. The predicament the tie vote created, in tandem with Burr's apparent satisfaction if the election went in his favor, heightened concerns about a system ill equipped for the emergence of political parties. Moreover, that such an unintended outcome might have occurred so early in the nation's history did not bode well for future presidential elections.

With an individual of Aaron Burr's suspect character so dangerously close to winning the presidency, coupled with the increasingly competitive and partisan nature of American politics, Congress chose to act. The move Congress made was toward constructing a new method for formally electing the president and vice president. In order to affect such a change, however, the Constitution had to be amended. On this account, 
there are just two ways the document may be amended; although, as of this writing, only one has ever been used. That method is as follows: the vote of two-thirds of both houses of Congress is necessary to propose an amendment to the document; then, approval of three-fourths of the state legislatures is required to ratify the amendment the Congress originally agreed upon. ${ }^{81}$

Despite competing proposals and the occasional incidence of acrimonious debate, the amendment to emerge from Congress was uncomplicated in purpose; the chief aim being the separate election of the president and vice president by the vote of the electors to the Electoral College. Henceforth, the electors were instructed to cast one of their two electoral votes explicitly for president; and their second vote specifically for vice president. After only four presidential elections, the vice presidency would no longer be a consolation prize for losing presidential candidates; it was to be, at least within the balloting of the Electoral College, finally a stand-alone elective office.

But reaching consensus on what became the Twelfth Amendment to the Constitution was not easily achieved and the proposal met with great resistance. In large part this may be explained by there never having been a great reserve of affection for the vice presidency. As debate on the Twelfth Amendment progressed, the prime complaints against the office, initially articulated sixteen years earlier at the Federal Convention, were revisited. This included discomfort in even establishing the vice president as an officer of the federal government.

Along these lines, a member of the House of Representatives from Connecticut, Samuel Dana, reminded his listeners of the historical haphazardness with which the vice presidency was instituted. Dana professed "that there is no necessity for this office... The 
idea of a Vice President did not suggest itself until the idea of a double ballot was introduced...Unless some great good result from the office of Vice President, no argument for its continuance can be deduced from the necessity of having an eventual successor." $" 82$

Like others in the Congress, Representative Dana did not approach the proposed amendment to the Constitution solely as a means to improve the manner in which the president and vice president were chosen. Instead, Dana was seizing on the amendment as a convenient way to excise the vice presidency from the document and from the government. As such, a large share of the debate within the Congress focused on the few places where the vice president fit. From there the debate, based almost entirely on the irrelevance of the institution, was a systematic argument for the abolishment of the office. $^{83}$

One tack taken by those attempting to purge the Constitution of the vice presidency was to address the core principle of the proposed amendment--that being to redirect the electors of the Electoral College to cast separate votes for president and vice president--and then juxtapose that with the original intent of the Framers, which gave the vice presidency to the second place finisher for president. To the original arrangement, James Madison had proffered to the Federal Convention that the outcome of casting two votes for president might very well be "the second best man in this case would probably be the first, in fact." 84

Ultimately, altering the feature of presidential selection that filled the second spot in government with individuals of, presumably, presidential caliber, could result in the vice presidency having even less appeal than was already the case. For this reason, the 
amendment put the presidency itself at stake. Since the electors to the Electoral College would be casting separate votes for president and vice president, but the vice president was still presumed to be the designated successor to the president, a candidate never intended for the presidency might easily end up there.

It was a plausible outcome that caused concern for many in Congress, and led one, Vermont's James Elliot, to assert that "the amendment will make the Constitution worse than it now is, believing as I do that it may bring a man into the Presidency, not contemplated by the people for that office." ${ }^{" 85}$ Then again, as one representative pointed out, should "the office of Vice President... be abolished, every Elector will give one vote, and that vote will be for President." ${ }^{" 86}$

And what of the responsibilities that came with the vice president's other title: president of the Senate? Roger Griswold, another member of Connecticut's House delegation, posed and then answered the bluntest of questions, with respect to the necessity of the vice president presiding in the Senate. Speaking of the vice president, Griswold asked: "Will he be wanted to preside in the Senate? That will not be necessary, for the Senate sit half their time without the Vice President, and I have not understood that the business is not as well done without as with him." ${ }^{17}$

When it came to the president and the vice president, succession, and altering the procedures of the Electoral College, Representative Griswold was no less forgiving. Arguing against passage of the amendment, Griswold claimed the value of the vice presidency, assuming there was some value there, would be diminished by casting ballots specifically for president and vice president. Such a method, Griswold suggested, would cultivate an arrangement whereby the "Vice President will be carried to market to 
purchase the votes of particular States...If it be your desire to consider the Vice President as heir apparent to the Presidency, elect him not in this manner, for he must be the mere child of corruption!" 88

When the amendment was finally approved by both houses of the Congress, the ratification process began, and the proposed Twelfth Amendment then went from state to state. In New York, Alexander Hamilton was the chief advocate for the amendment and the sole author of the "Proposal for the New York Legislature for Amending the Constitution.. ${ }^{, 89}$ Hamilton argued ratification of the Twelfth Amendment was imperative "as a necessary safeguard in the choice of a President and Vice President against pernicious dissensions [and] as the most eligible mode of obtaining a full and fair expression of the public will in such election. ${ }^{90}$ For Hamilton, and others of his ilk, the best way to steer clear of any disagreeable electoral incidents, akin to what transpired in the 1800 election, was to ensure that "the persons voted for shall be particularly designated by declaring which is voted for as President and which as Vice President."91 Less than a year after Congress initiated the ratification process, and after ample deliberation on the merits of the amendment in the state legislatures, thirteen of the seventeen states then in the Union had agreed to the changes delineated by Congress. In part, the Twelfth Amendment reads:

The Electors shall meet in their respective states, and vote by ballot for President and Vice-President, one of whom, at least, shall not be an inhabitant of the same State with themselves; they shall name in their ballots the person voted for as President, and in distinct ballots the person voted for as Vice-President, and they shall make distinct lists of all persons voted for as President, and of all persons 
voted for as Vice-President, and of the number of votes for each, which lists they shall sign and certify, and transmit sealed to the seat of the government of the United States, directed to the President of the Senate...The person having the greatest number of votes for President, shall be the President...The person having the greatest number of votes as Vice-President, shall be the Vice-President. ${ }^{92}$

Apart from the antiquated language of the Twelfth Amendment, the mechanics of the amendment were straightforward: instructing the electors of the Electoral College to isolate their vote for president, and to then do the same with their vote for vice president. Yet the simplicity of the revised mechanics for electing the president and vice president did not portend the subsequent, long-term impact the amendment was to have on the vice presidency.

To begin with, a major consequence of the Twelfth Amendment was that defeated presidential candidates were unlikely to inhabitant the office of vice president; for having lost a bid for the presidency, few would ever consent to run expressly for the vice presidency in a future election. In addition, with the second place finisher for president no longer relegated to the vice presidency, the initiation of the Twelfth Amendment effectively tempered genuine interest in the vice presidency for many capable individuals who might have considered it a stepping stone to the highest office in the land--as it had been for John Adams and Thomas Jefferson. This then became a contradiction unique to the Twelfth Amendment: while it provided for the transparent election of a specific individual for vice president, it also dramatically reduced the pool of high quality individuals willing to settle for the office. 
The Twelfth Amendment also cemented the pattern of political parties presenting a team of candidates for the two highest offices; a practice that actually began with the first contest between Adams and Jefferson. ${ }^{93}$ As was already shown, the appearance of political parties was to have a major impact on the system that had worked so well for the first two presidential elections. In essence, the intent and integrity of the original system had been corrupted by the machinations of political parties. And though the men responsible for constructing the Constitution had prepared for many contingencies, the document was lacking any reference to political parties. On this account, the Framers were remiss in not better preparing for the appearance of political parties--or at least something resembling such groups. Because, as one scholar has pointed out, by 1800 the political parties had successfully "upset the applecart on the two-votes-for-President system." 94 And it was reasonable to assume political parties would not stop there.

For a number of years then, the caliber of individuals to assume the vice presidency fluctuated greatly. This is partly attributable to the absence of any genuinely attractive powers and responsibilities ever having been affixed to the institution. Still, and irrespective of the want in functions for the vice president, if many of the individuals to land in the vice presidency were unremarkable, some of the earlier occupants--such as Elbridge Gerry and John Calhoun--were gifted political leaders in their own right. While acknowledging some of earliest vice presidents possessed commendable intellect and political aptitude does further the narrative of the institution, there was another unanticipated consequence from the implementation of the Twelfth Amendment that deserves attention. For after the Twelfth Amendment, there was an undeniable and striking change in the age of some of the individuals elected to the office. ${ }^{95}$ 
For instance, whereas Aaron Burr was inaugurated as Thomas Jefferson's first vice president when he was just forty-five; Jefferson took George Clinton, at the age of sixty-five, for his second vice president. Clinton went on to serve nearly all of a second term in the vice presidency--in the service of President James Madison--though he eventually died while in office when he was seventy-three. Similarly, Clinton's immediate successor, Elbridge Gerry, was sworn in to office at the advanced age of sixtynine. Like Clinton, Gerry too died in office, less than two years into his term.

Even if electing elderly vice presidents failed to be a long-term trend, it was indicative of the value placed at that time on those who were candidates for vice president. Further contributing to the perception of a dispensable vice president was that, up to April of 1841, no president had died while in office. It was not until the death of the ninth president, William Henry Harrison, and the elevation of John Tyler from the vice presidency to the presidency, that there was any concern for who served as vice president--and even that concern almost immediately evaporated. 


\section{The Vice President as Presidential Successor}

"In upwards of half a century, this is the first instance of a Vice-President's being called to act as President of the United States, and brings to the test that provision of the Constitution which places in the Executive chair a man never thought of for it by anybody. The day was in every sense gloomy--rain the whole day." 96

(Diary entry of John Quincy Adams, April 4, 1841)

Apart from the vice president's role presiding in the Senate, in every way the vice presidency is attached to the presidency. This holds true when, under specific circumstances dictated by the Constitution, it becomes necessary for the vice president to replace the president, and exercise the duties of the higher office. What is remarkable, however, is that it took over half a century, from the time of the inauguration of the first president and vice president, before presidential succession was ever put to the test. But when presidential succession was finally put in practice, being vice president took on an entirely new meaning.

John Tyler will always be conspicuous among vice presidents. Not because he was an unusually brilliant or talented vice president; and surely not because he achieved a great deal when he held the office. For that matter, he barely had time to make a mark, serving only one month under President William Henry Harrison. What makes Tyler particularly noteworthy, however, is his place as the first vice president in American history to succeed to the presidency. This honor landing on Tyler first was obviously a fluke--at the time, some referred to the newly elevated president as "His Accidency"--but Harrison's demise, and Tyler's subsequent rise to the presidency, proved significant in establishing the vice president as the acknowledged successor to the president. ${ }^{97}$ 
Having never before been confronted with the death of the president while in office, there was no obvious precedent to follow. Thus, Tyler found himself in unexplored territory that presented several challenges; paramount among these was deciphering the intent of the Framers with respect to the Constitution, and to the replacement of the president. But determining the plan for presidential succession was not an easy task; nor was the constitutional ambiguity made any clearer by an examination of the proceedings of the Federal Convention of 1787. As it was, the record of the Convention on presidential succession plainly added to the uncertainty.

On the matter of succession, historian Arthur Schlesinger Jr. observed that the "Convention did not resort to the Vice Presidency in order to solve the problem of succession," and had recommended instead that the President of the Senate--presumably whomever the Senate had selected for the position at that time--should assume the powers and duties of the president, but only until the election of a new president. ${ }^{98}$ Furthermore, the Convention delegates were inclined to have the legislature choose "what officer of the U.S. shall act as President in case of the death, resignation, or disability of the President and Vice-President; and such officer shall act accordingly until the time of electing a President shall arrive." ${ }^{99}$ And yet, James Madison countered that the foregoing, "as worded, would prevent a supply of the vacancy by an intermediate election of the President," and therefore he recommended modifying the language so as not to prevent having the successor serve only until a new election for president might feasibly be held. ${ }^{100}$

Clearly there were alternate perspectives on how best to resolve the succession question; and it is apparent the Framers anticipated that, sooner or later, the nation would 
find itself confronted with the circumstances of 1841. Undoubtedly it is why they included the death of the president in the list of vacancy-inducing possibilities for the office. Yet even if the death of the president is a contingency addressed in the Constitution, how the transfer of power is meant to proceed is only marginally hinted at: In Case of the Removal of the President from Office, or of his Death, Resignation, or Inability to discharge the Powers and Duties of the said Office, the Same shall devolve on the Vice President, and the Congress may by Law provide for the Case of Removal, Death, Resignation or Inability, both of the President and Vice President, declaring what Officer shall then act as President, and such Officer shall act accordingly, until the Disability be removed, or a President shall be elected. ${ }^{101}$

This passage from the Constitution is clear as to the power of the Congress to replace both the president and vice president--on those occasions when there is a double vacancy--but it is less obvious what is to happen to the vice president, once the president is no longer in office. In delineating that "the Same shall devolve on the Vice President," the Framers embraced nuanced language to convey their intent--whatever that might have been. As a consequence, it was evident the powers and duties of the president were meant to "devolve" onto the vice president. But were the devolved powers and duties temporary, meant only to last until a new election? President Harrison's cabinet apparently took this view, as they had decided in the immediate aftermath of Harrison's death that John Tyler should be addressed as "Vice President, acting as President.", 102 
But was President Harrison's cabinet misconstruing the plan of the Framers? If the Framers intended the vice president to assume all of the powers and the duties of the president, did they expect the arrangement to stand for the remainder of the president's term? Tyler deemed the answer to be yes. His read of the Constitution was fairly simple: the vice president was not meant to be a transitory replacement for the president. From Tyler's point of view, the death of the president meant the vice president assumed the presidency and everything that came with it--including the nearly four years remaining in Harrison's term.

What made Tyler's approach to presidential succession so successful was the alacrity with which he acted. Within hours of being notified of President Harrison's death, Tyler made his way to the capital city; once there, he convened a meeting of Harrison's cabinet--all of whom he decided to keep in his own administration--and then he was sworn in to office, making him the tenth president of the United States. Being sworn in as the new president was an additional precedent that Tyler reluctantly established; it was his read of the Constitution that, with the death of the president, it was preordained the vice president was the new president--sans a second oath. ${ }^{103}$ Put another way, because Tyler had previously sworn to defend the Constitution when he took the vice-presidential oath, he was certain reiterating that pledge was unnecessary. Either way, Tyler repeated the presidential oath of office, in the words of one historian, "to remove any doubt about his status."

There were two outcomes of John Tyler's assumption of the presidency that were likely overlooked at the time. First, by swiftly taking the helm of the Harrison administration, Tyler preserved the elected government of the people. This was a logical 
outcome; Tyler was, after all, the vice president and he had been elected with the president. And second, in affecting a successful and peaceful transition of power, Tyler helped validate the stability of the relatively young American political system. It is precisely because of these dual outcomes that one scholar has argued the "existence of an established institution of succession, is..., a most vital function. It is of the utmost significance that provision has been made for succession to occur with the least possible delay so that an hiatus in the functioning of government not occur." 105

The choices John Tyler made incontrovertibly institutionalized the procedures that would be followed when filling every subsequent vacancy in the presidency. Had Tyler been less assertive, and simply acquiesced to being the "Vice President, acting as President," then the office of vice president would surely have been more repellant than it already was. As it stood, with Tyler's move to the presidency ultimately going uncontested, the development of the vice presidency advanced considerably. The Succession Acts of 1792, 1886, and 1947

John Tyler's ascension from vice president to president did more than set the precedent on presidential succession; it created the fourth vacancy in the history of the vice presidency. Considering that Tyler was the tenth elected vice president meant, statistically, that nearly 50 percent of vice presidents, up to that point in time, had either died while holding office--George Clinton and Elbridge Gerry--resigned--John Calhoun-or succeeded to the presidency, as Tyler did. Notwithstanding, the frequency of vacancies in the vice presidency, there was no concerted effort to rectify the situation.

Congress was not, however, entirely idle with respect to succession. The three major congressional acts relating to presidential succession, each named for the year 
enacted, are included here primarily for what the three acts do not address. In no way did the Succession Acts of 1792, 1886, or 1947 address the absence of any mechanism to replace the vice president. The failure of Congress to create a means for filling the second office in the land if the vice president succeeded to the presidency, resigned, was impeached, or died while in office, indicated the indifference for the institution in the succession equation. It also furthered the idea of the vice president being unessential to the day-to-day operation of the national government.

The death of Vice President George Clinton no doubt brought grief to those who knew him; but it also presented a quandary for which the Framers apparently never spent a great deal of time preparing for. The quandary was this: who should succeed to the presidency if both the president and the vice president resigned, were removed from office, or died? Hence, with Clinton's death being the first for a vice president or president, succession was naturally of concern. Yet in this regard, Clinton's contemporaries were at a loss, for the Framers failed to indicate a preference for succession, instead leaving these matters for Congress to decide in the future. Therefore, the Constitution originally directed that "the Congress may by Law provide for the Case of Removal, Death, Resignation or Inability, both of the President and Vice President, declaring what Officer shall then act as President, and such Officer shall act accordingly, until the Disability be removed, or a President shall be elected."106

Congress did try to rectify the lack of direction on presidential succession-although not vice-presidential succession--crafting and eventually approving the Presidential Succession Act of 1792. In the prelude to passage of the act, much of the debate centered on whether the secretary of state should be next in line to the presidency; 
or if the president pro tempore of the Senate and the Speaker of the House should be the designated successors. Aversion to making the secretary of state the successor to the president came primarily from outside of the Congress, and in the form of Alexander Hamilton. Hamilton was consumed by inflated fears that his long-time adversary, Thomas Jefferson, then serving as the nation's first secretary of state, might stealthily enter the presidency by way of succession. ${ }^{107}$ And while some members of Congress were understandably reluctant to designate one of their own for the presidency, since it could disrupt the separation of powers built into the Constitution, it was not enough of a concern to dissuade either house of Congress from passing the act. ${ }^{108}$ Then again, preserving the separation of powers might not have been as strong an incentive for those in Congress who wanted to protect their interests if their political party already held control of the White House.

Congress waited a mere ninety-four years before it again crafted and passed legislation to deal with presidential succession. In the interim, five vice presidents died while in office, one resigned, and four had ascended to the presidency upon the death of the president. But the move by Congress in 1885 to address presidential succession was not founded on any disquietude with the inadequacies of the original succession provision of the Constitution. It was driven instead by partisan politics and a perfectly reasonable unease that control of the executive branch could shift to the opposition party, on those occasions when the president and vice president were not of the majority political party in Congress.

The solution Congress devised was straightforward and effective; moving the line of succession away from itself, and over to the cabinet. Not only did this ensure that 
potential presidential successors were of the same political persuasion as the president; it also retained the spirit of the Constitution in calling for an officer of the United States to act as president. This principle had been violated with passage of the Presidential Succession Act of 1792 and the introduction of members of Congress into the line of succession. Subsequently, President Grover Cleveland signed the Presidential Succession Act of 1886, making officers of the cabinet presidential successors upon the death, resignation, or inability of both the elected president and vice president. ${ }^{109}$ Unsurprisingly, the Succession Act of 1886 failed to even consider, let alone devise, a method for filling vacancies in the vice presidency; it would take another eighty-one years and a constitutional amendment before that deficiency in the Constitution was rectified.

Congress next revisited presidential succession in 1945, following the death of President Franklin Roosevelt. Roosevelt's death made his third vice president, Harry Truman, president, less than three months from the day of their inauguration. Given that Truman did not have a vice president for almost four years; it made sense when he called for revisions to the law on presidential succession. ${ }^{110}$ Truman's principal objection to the Presidential Succession Act of 1886 was with the unelected status of cabinet members. Because the cabinet was composed of individuals nominated by the president, and approved by the Senate, Truman noted it was at his discretion to nominate a potential successor; and this, he argued, was undemocratic. ${ }^{111}$

Ultimately, Truman's preferred line of succession prevailed and he signed the Presidential Succession Act of $1947 .{ }^{112}$ The 1947 act established a line of succession that began, after the vice president obviously, with the Speaker of the House; followed by the 
president pro tempore of the Senate; and finally the cabinet. The order of succession from within the cabinet started with the secretary of state, followed by each cabinet secretary, with their place determined by when the executive departments had been established.

There was poignancy to President Truman signing the Presidential Succession Act of 1947. As a former vice president who had made it to the presidency upon the death of the president, Truman intimately understood the significance of the succession provision of the Constitution. Moreover, by 1947 Truman was serving his third year as president-the entire time without a vice president. But just as it was with each of the previous attempts to organize presidential succession, the Presidential Succession Act of 1947 failed to address how vacancies in the vice presidency should be filled. Evidently the president and the Congress did not consider the vice president as an indispensable officer of the government. 


\section{Precedent by Presidential Prerogative: The Cabinet}

"My experience in the Cabinet was of supreme value to me when I became President."113 (Former vice president Calvin Coolidge)

The influence of any president on the vice presidency should not be underestimated. When evaluating the institutional development of the vice presidency the president-to-vice president arrangement is without question the most salient indicator of what form specific vice presidencies take on. And while this has been the case throughout the historical arc of the vice presidency, even as the modern president-to-vice president association has increasingly resembled a governing partnership, the vice-presidential institution continues to rely on the incumbent president for its ongoing viability.

In a historical context, nowhere did a president have a greater impact on the vice presidency than in 1921, with the inauguration of President Warren Harding. For that matter, Harding articulated his view on the form the modern vice presidency might take well before he and his running mate, then-Governor Calvin Coolidge, took office. For that era, Harding professed singular notions of what the vice president could be in a future Harding administration. During the 1920 campaign, Harding put it this way: I think the Vice-President should be more than a mere substitute in waiting. In reestablishing coordination between the Executive office and the Senate, the Vice-President can and ought to play a big part, and I have been telling Governor Coolidge how much I wish him to be not only a participant in the campaign, but how much I wish him to be a helpful part of a Republican Administration. The country needs the counsel and the becoming participation in government of such men as Governor Coolidge. ${ }^{114}$ 
Harding's suggestion that a prospective vice president should offer counsel to the president and participate in a future administration was an unusual utterance from a presidential candidate, coming when it did in the early decades of the twentieth century. In part, claiming the vice president was well suited for "coordination between" the executive and legislative branches made sense. The vice presidency had always been a hybrid institution: elected with the only other national executive; yet having constitutionally sanctioned responsibilities in the legislative branch, though only in one of the two chambers of Congress.

Because there was an expectation for the vice president to preside, at least some of the time, in the Senate, then the utility in having the vice president facilitate relations between that body and the executive was apparent. But Harding's plan for the vice president in the Senate was not nearly as significant a contribution to the institutional vice presidency, as was his effort to draw the vice president into the executive. This came about when Harding--initially before the 1920 election, and then again after winning the presidency--proposed that Calvin Coolidge, as vice president, be present for meetings of the executive cabinet. ${ }^{115}$

But President Harding does not get credit for being the first president to suggest the vice president attend cabinet meetings. That idea originated with George Washington, who thought it appropriate for the nation's first vice president, John Adams, to attend cabinet meetings under specific circumstances. The caveat was Washington wanted Adams to be present at the meetings, and even to preside, but only when he was away. ${ }^{116}$ As for Adams: he seemed to view the office of the vice president as belonging strictly to 
the legislative branch; and on those occasions when he accepted Washington's offer, he felt unwelcome at meetings of the heads of the executive departments. ${ }^{117}$

Naturally, when Adams moved up to the presidency, he never suggested the incumbent vice president, Thomas Jefferson, should come near a meeting of the cabinet; though Adams's attitude on the matter was surely based more on his vice president being the head of the opposition political party, than with any concern over the legislativeexecutive divide of the vice presidency. Similarly, when Woodrow Wilson was president, he too offered a place at the cabinet table to the sitting vice president, Thomas Marshall. But, like President Washington had before him, Wilson's offer was contingent on his own absence from the meetings, and that Marshall should be present merely to manage the proceedings.

Woodrow Wilson's aversion towards making use of his vice president is not surprising. Twenty-eight years prior to Wilson's move to the White House, the future president devoted a single paragraph in a comprehensive treatise on the three branches of the United States government, to a scathing critique of the American vice presidency. ${ }^{118}$ In Wilson's words, the vice presidency was a position “of anomalous insignificance and curious uncertainty," and when all was said and done, "the chief embarrassment in discussing his office is, that in explaining how little there is to be said about it one has evidently said all there is to say.",119

Most likely, Wilson's derisiveness was not founded wholly on disdain for what appeared to be an orphaned institution. Yet in professing puzzlement at where exactly the vice president belonged in the scheme of the government, Wilson was underscoring a fundamental paradox of the American vice presidency. The paradox was this: while the 
vice president was one of the two nationally elected executive officers in the United States political system, there was no expectation for the vice president to participate in the executive branch; nor was there a single constitutionally sanctioned duty in the executive realm. And because the vice president did not hold authority or responsibilities equivalent to the heads of the executive departments, presumably the vice president was not a necessary addition to cabinet deliberations.

The Framers had been explicit when attaching the vice president to the executive branch, in tandem with the president, but only in mode of election. Likewise, the Framers had delimited the functions of the vice presidency by appending the vice president to the legislative branch in the innocuous role of the president of the Senate. In that role, the vice president was not to participate in the debates of the chamber, and was given a vote solely for those occasions when the membership was equally divided. It was the transparently impotent nature of the institution that led a former assistant to President Truman to claim--when testifying before a congressional committee on the reorganization of the executive branch, broadly, and the efficacy of the vice presidency, specifically-that if the Constitution was "the greatest instrument ever struck off by the hand of man," when it came the establishment of the vice-presidential institution, the Framers failed to "come up to the same high standard as they did in other phases of their constitutional effort." ${ }^{120}$

But if Woodrow Wilson seemed at a loss for where the vice president properly belonged, apparently Warren Harding and Calvin Coolidge agreed the answer might lie, to some extent, in cabinet attendance. While Coolidge was far from an activist when at meetings of the president's cabinet, his presence there meant the vice president could be 
attached, if only symbolically, to the highest councils of the executive government. ${ }^{121}$ Put another way, if Vice President Coolidge, when attending cabinet meetings was--in the words of Harding's attorney general--simply "a wonderful listener" who "never intruded his views unless asked for them," it did not matter; what mattered was the vice president was at the table. ${ }^{122}$

Harding's inclusion of the vice president within the exclusivity of the executive cabinet was remarkable in that it helped to diminish a measure of the ambiguity surrounding the vice president's place in the executive branch, and from that point forward marked the vice president as an undeniable presence in the executive government. Certainly Harding's gesture to Coolidge would prove to be among the best outcomes of his brief time as president; it would also, with one exception, set the precedent for all successive vice presidents to routinely attend meetings of the cabinet. ${ }^{123}$ What is more, when President Harding established what was to become a precedent of the vice president sitting with the cabinet, he had inadvertently facilitated the arrival of the modern American vice presidency. ${ }^{124}$

As for Calvin Coolidge: if he functioned in the president's cabinet principally as a witness to the deliberations, he was certain that his presence there was an invaluable experience for him. Writing from the vantage of having already served in both the vice presidency and the presidency, Coolidge illustrated the utility in having the vice president in the cabinet in this way:

If the Vice-President is a man of discretion and character, so that he can be relied upon to act as a subordinate in such position, he should be invited to sit with the Cabinet...He may not help much in its deliberations, and only on rare occasions 
would he be a useful contact with the Congress, although his advice on the sentiment of the Senate is of much value, but he should be in the Cabinet because he might become President and ought to be informed on the policies of the administration...But he will hear much and learn how to find out more if it ever becomes necessary. My experience in the Cabinet was of supreme value to me when I became President. ${ }^{125}$

Ironically, the sole exception to the vice president regularly sitting with the cabinet was Coolidge's own vice president, Charles Dawes. Dawes did not believe the vice president belonged in the cabinet; he claimed "the official relations of the President and Vice President lend themselves to the encouragement of misapprehensions which are easy to create. I have always sensed the inherent embarrassments involved in the plan of having the Vice President sit in the Cabinet, as Coolidge did under the Harding administration." 126

Despite the objections of Charles Dawes to the vice president's presence at cabinet meetings, the practice resumed with the next executive pairing of President Herbert Hoover and Vice President Charles Curtis in 1929, and it has continued uninterrupted ever since. ${ }^{127}$ Therefore, as of this writing incumbent vice presidents have been included in meetings of the cabinet for over ninety years. To this point, it has been suggested that "shifts in authority for a half-century, in the same polity, and with some broader context of years, without getting reversed or deflected, are, prima facie, durable in a way that shifts that hold for a decade or less are not."128 The significance of this is the permanence with which the vice president has now been linked, in a fashion, to the 
executive branch.

Although the vice president does not have constitutionally defined "authority" apart from presiding in the Senate, the notion that presidents have consistently included their vice presidents in meeting of the heads of the executive departments implies the vice president has authority on par with others who sit with the cabinet. The continuity of this arrangement is the most prominent indicator of a "durable" shift in the vice presidency from being principally an institution of the national legislature; to an institution more closely identified with, and indeed integrated into, the executive branch. More importantly, when a president added the vice president to the cabinet, and then successive presidents maintained the arrangement, the structure was in place for the ongoing augmentation of the vice-presidential institution by presidential fiat. 


\section{Institutional Development by Portfolio and Statute}

"The question should be asked whether the President could not profitably avail himself of a Vice President who, while informing himself of duties that he may at any time be called upon to fulfill, would execute a kind of roving commission for the Chief Executive, lending a hand wherever possible.",129

(Assistant secretary of the Navy and 1920 Democratic Party candidate for vice president, Franklin Roosevelt)

Certainly the development of the American vice presidency has been influenced by formal, concrete measures; most obviously with the initial inclusion of the office in the Constitution, as well as subsequent constitutional amendments. Yet there are institutional markers that are less formal, and do not require alterations to the existent charter for the United States government, but nonetheless have transparently added to and accelerated the development of the institution. Included among the latter institutional markers is the assignment by a president of specific policy portfolios; and the advancement of statutes and executive orders by a president that purposively enhance the stature and visibility of the vice presidency.

\section{The Vice President as Bureau Chief}

Because the only work the vice president was expected to do was to preside in the Senate, and even that chore has been easily turned over to a president pro tempore chosen by the members of the chamber, it made sense to make better use of the incumbent vice president. Even so, there had been a peculiar reluctance to give the vice president much to do outside of the Senate; and though there were exceptions throughout the history of the institution, whereby certain presidents had consulted and depended on their vice 
president to a greater extent than is widely known, by and large, it was the nature of the office to be left alone. ${ }^{130}$

On occasion vice presidents were given assignments by their president; however, these varied and there was no certainty that successive vice presidents would be similarly tasked. The earliest exception to this was when the vice president, regardless of who held the office, was designated a permanent regent of the Smithsonian Institution. If a regent posting at the Smithsonian was perfunctory, it was nonetheless a concrete and formal addition to the institutional profile of the vice presidency. Additionally, including the vice president to the Smithsonian's board of regents may be framed as the precursor to modern presidents assigning their vice presidents to assorted executive commissions and councils; it was a practice which became the norm and further augmented the vicepresidential institution.

It was the opinion of the twenty-eighth vice president, however, that making the second officer of the government a regent of the Smithsonian was simply a ruse used to prevent that officer from doing any harm. Thomas Marshall was the vice president in question. Even though Marshall's tenure is fittingly overlooked today, his observations on the vice presidency are worthwhile because he was intimately familiar with the institution, having served in the post for eight years. Furthermore, his recollections, juxtaposed with the state of the modern vice presidency, underscore just how far the institution has come since he committed his thoughts to paper, eighty-six years ago. Marshall claimed:

Since the days of John Adams there has been a dread and fear that some vice-president of the United States would break loose and raise hell...with the 
administration. Everything that can be done, therefore, is done to furnish him with some innocuous occupation. They seek to put him where he can do no harm. Among the other nameless, unremembered things given him to do is the making of him a regent of the Smithsonian Institution. There, if anywhere, he has an opportunity to compare his fossilized life with the fossils of all ages. ${ }^{131}$

Irrespective of the dim view Thomas Marshall took toward the vice president's obligations outside of the Senate, beginning in 1941, every president began to increase the workload of their vice president with the assignment of specific policy portfolios. By giving the vice president various policy portfolios, the potential utility of the office was further underscored and, in turn, the development of the institution was extended in new and different ways.

In 1941 Franklin Roosevelt was beginning his third term as president. Roosevelt had first run for national office in 1920, when he was the vice-presidential nominee of the Democratic Party. At that time, Roosevelt composed an article in which he argued the vice president could be a more useful figure in the government. ${ }^{132}$ No doubt Roosevelt had himself in mind when he wrote the article, in the hopes of winning the vice presidency and then assuming his running mate, the candidate for president, Governor James Cox, would follow his recommendations for an improved second office. The CoxRoosevelt ticket lost the election, but when Roosevelt later became the president, he implemented elements of his earlier plan to develop the vice presidency.

Franklin Roosevelt was unique among presidents on a number of accounts. It is therefore not surprising that when it came to the vice presidency, he left his imprint on 
that institution, as well. To start, Roosevelt, unlike any other president, would be elected to the presidency four times; he would also be the only president in history to serve alongside three different vice presidents: John Nance Garner, Henry Wallace, and Harry Truman.

As president, Roosevelt expanded the responsibilities of the vice president; as a result, he raised expectations for the office, and for whoever might hold it. In his first vice president, John Garner, Roosevelt had the liaison to Congress that he had proposed when writing of the office in 1920; although he and Garner eventually parted ways, and scarcely communicated with one another in the last two years of their service together. ${ }^{133}$ And with regard to his third vice president, Harry Truman: Roosevelt hardly knew Truman before the latter man made it onto the Democratic ticket in 1944; and then Roosevelt died, just eighty-three days into the Truman vice presidency. How Roosevelt might have used Truman will never be known.

What is known is how Roosevelt's choice of Henry Wallace for his second vice president laid the groundwork for the future, more substantial, vice-presidential institution. As it happens, Roosevelt had an impact on the vice presidency in an unanticipated way when, at the 1940 Democratic nominating convention, he insisted on Wallace for his running mate; even going so far as to suggest he would not accept the nomination for president if Wallace was not the nominee for vice president. ${ }^{134}$ According to Wallace, "Roosevelt had been completely for me in 1940, when for the only time in history a presidential candidate had named precisely the man he wanted to run with him." 135

From that time forward, the initial selection of the vice-presidential nominee 
became, for both major political parties in the United States, the prerogative of the nominee for president. In this, Roosevelt had set a precedent which solidified the connection between presidents and vice presidents, making victorious vice-presidential nominees indebted to the president who was responsible for their selection.

In Wallace, Roosevelt had gained a confidant and vice president who could be placed wherever needed; what is more, Wallace would prove to be an exceptionally cerebral philosopher for the Roosevelt administration. ${ }^{136}$ Wallace had served as the secretary of agriculture for the first eight years of Roosevelt's presidency; in that time he emerged as the most effective department head in the executive branch. It was no surprise then, as the Wallace vice presidency moved forward, that Wallace personified the vice president as public administrator.

It was as the chief administrator of the Economic Defense Board (EDB), and later for the expanded and renamed Board of Economic Warfare (BEW), that Wallace was put to work by Roosevelt in a way that no vice president before him ever had. In particular, in the time period leading to the Second World War, and then after the United States formally entered the conflict, Wallace efficiently managed several government entities with myriad responsibilities, and nearly all of which fell under the umbrella of either the EDB or the BEW. Among the agencies Wallace commanded was the Office of Exports; the Office of Imports; and the Office of Warfare Analysis. The latter of the preceding three agencies was especially vital in the war effort; its principal mission being the determination of which foreign targets should be bombed, based on the economic value to enemy nations of those targets. 
Wallace succeeded on many levels during his tenure running the BEW; at the same time, his objectives were oftentimes undercut by the enmity and competitiveness that frequently arises amongst competing bureaucratic organizations. Most notably, Roosevelt's secretary of the commerce, Jesse Jones, was an ideological adversary of Wallace and would prove to be a habitual antagonist to him for most of the four years he was vice president. ${ }^{137}$ Jones had controlled the Reconstruction Finance Corporation (RFC) since the Hoover administration; it was a federal corporation mandated to borrow and disburse money to other federal agencies. Much of Wallace's far-reaching vision for the United States and for the world, once the war was won, and which he hoped to implement via the work of the BEW and its sub agencies, depended on the cooperation and largesse of the RFC--but only if Jones approved funding.

Today the specifics of the conflict between Wallace and Jones are not relevant; many times their disputes were petty, fueled primarily by stubbornness and political gamesmanship. What is important is the episodic infighting Wallace and Jones engaged in threatened to destabilize the domestic wartime objectives that President Roosevelt had set for the two men, their subordinates, and the government agencies they oversaw. Roosevelt was known to loathe when administration infighting went public; so as the Wallace-Jones clash was increasingly waged in the press, Roosevelt found himself in an untenable position.

Because Jones was a member of the cabinet, he was utterly dependent on the president for his employment; on the other hand, Wallace was an elected officer of the government and was not as easily dismissed. But Wallace and Jones relied on the authority conveyed on them by the president; therefore, Roosevelt could exercise his 
prerogative to withdraw the authority he had given each man. As such, Roosevelt abolished the BEW; left a shell of the RFC; and simply vested power in a new wartime agency to manage the most vital functions of the BEW and RFC.

By giving his vice president control of a bureaucratic agency, President Roosevelt had marked the office of vice president as one with greater utility than what was provided for in the Constitution. In the process, Roosevelt demonstrated that he could, as the president, influence the expansion of an institution of the government, and do so without having the concurrence of either the legislative or the judiciary branches. Conversely, Roosevelt showed that presidents may retract of their own volition any authority or assignments given to vice presidents. It was a phenomenon unique to the president-tovice president association in that, in the American system of government, there is no other pair of institutions whereby one may so decidedly determine the form and the function of the other. Vice President Hubert Humphrey later encapsulated this phenomenon in what he called "Humphrey's law": "He who giveth can taketh away and often does." ${ }^{138}$ Plainly he had his relationship with President Lyndon Johnson in mind, but "Humphrey's law" is applicable to every president-to-vice president association to precede, as well as to follow, that of Johnson and Humphrey.

Notwithstanding the demise of the BEW, specifically, Franklin Roosevelt had set precedent where it concerned the vice presidency. Just as he had done when forcing his personal selection for the vice-presidential nomination in 1940, Roosevelt had acted unilaterally in granting Vice President Wallace authority to oversee an agency of the executive branch. By his actions on this front, Roosevelt helped foster the visibility of the office of vice president, while giving the vice president authority commensurate to that of 
a cabinet secretary. This put Wallace in a unique position: he was an officer of the government whose purview equaled executive department heads, but his election with the president ranked him higher than those he sat with in the cabinet. ${ }^{139}$

There was an auxiliary outcome of Roosevelt's placement of Wallace at the head of an executive agency. By authorizing his vice president to direct a wartime agency, one that was competitive with other agencies of the government, Roosevelt had drawn the vice president further into the political infighting which sometimes characterizes the pursuit of divergent policy goals within an administration. While the intersection of government and politics is frequented by many institutions, the vice president, being essentially a powerless officer of the government, is associated most with the politics of elections, and not the politics of policy advancement. And yet, as vice president and board chief, Wallace's talents as public administrator, economist, and advocate for social justice increasingly brought him into the political realm. Unfortunately, it was the political jockeying between Wallace and Jessie Jones that ultimately led to the dissolution of the first government agency ever headed by a vice president.

Henry Wallace understood the depth of his usefulness to President Roosevelt, but he was equally aware he was moving in a direction unfamiliar to the vice presidency. It was perhaps for this reason that in some quarters Wallace's tenure was considered a failed experiment in reforming the vice presidency. But in focusing on where politics impeded Wallace's efforts, the long-term effect of Roosevelt's use of the vice president is easily overlooked. By harnessing the unique talents of his second vice president, Roosevelt accelerated the development of the vice presidency more than he could have anticipated. In making the vice president a thoroughly utilitarian officer of the executive 
branch, Roosevelt had put in motion much of what he had proposed in 1920 for the vice presidency. Of more importance to the development of the vice-presidential institution, however, was that every president to follow Franklin Roosevelt in office built on what he had started. For these reasons, moving toward the middle of the twentieth century, the vice presidency had become a more valuable and visible institution of the government and, as a consequence, a more attractive office for ambitious political figures to seek and to hold.

\section{Assigning the Vice President to Councils and Commissions}

President Franklin Roosevelt's elevation of the vice presidency to a meaningful office of the government was achieved by his having the vice president administer an agency of the executive government for the first time in the nation's history, and therefore assigning a specific policy portfolio to the vice president. By initiating the preceding, Roosevelt built on the paradigm for the modern vice presidency, the foundation for which had been set by President Warren Harding with his invitation to Vice President Calving Coolidge to sit with the cabinet. Even with Roosevelt's disbanding of the administrative sphere he had created for Vice President Henry Wallace, the precedent had been set.

As noted previously, Harry Truman succeeded Henry Wallace in the vice presidency. It is common knowledge that in the time Truman was the vice president he was never informed of the existence of the atomic bomb; nor was he apprised of much else about the workings of the executive branch. Wallace, who Roosevelt brought back into the cabinet as the commerce secretary, after Wallace had been dropped from the Democratic ticket in 1944, noted in his diary that Truman "felt that during the time when 
he was Vice President, President Roosevelt had not taken him into his confidence about anything. He said rather plaintively, 'They didn't tell me anything about what was going on." ${ }^{140}$ Therefore, when Vice President Truman became President Truman he made certain his own vice president was thoroughly integrated into the executive government, especially in the area of national security. As expected, because there was no prescribed method for filling the vacancy in the vice presidency brought on by Truman's ascension to the presidency, President Truman had to wait nearly four years, after he was elected to his own term as president, to implement any enhancements to the vice presidency.

Elected with Truman in 1944 was Alben Barkley, a United States senator from Kentucky. According to Barkley, "Truman knew how little opportunity had been given in the past for Vice Presidents...to acquaint themselves with the job they might have to take over, and he wisely set out to rectify this situation." ${ }^{141}$ To this end, Truman continued the tradition of the vice president regularly attending meetings of the cabinet. But of greater significance to the development of the institutional vice presidency, Truman advanced the notion that the vice president should be consistently informed and included in the highest councils of the military and national security. Because of Truman's advocacy on this front, Congress passed, and Truman signed, the National Security Act of 1947.

In terms of the institutional markers of the development of the vice presidency, passage of the National Security Act of 1947 should be recognized for being one of the more prominent; in that it made the vice president a statutory member of the National Security Council (NSC). This was a remarkable boost to the vice presidency, coming just two years after an admittedly uninformed Harry Truman had succeeded to the presidency. In addition, there were three fundamental outcomes from making the vice president a 
member of the NSC. First, in constructing and enacting legislation making the vice president a member of the NSC, the Congress was finally acknowledging the vice president mattered. Second, by signing the National Security Act of 1947, President Truman had affixed the vice president to the executive branch by law. And third, similar to cabinet inclusion, by virtue of NSC membership, the vice president had an undeniable place at the side of the president.

Four years after their election together, Truman and Barkley were succeeded by Dwight Eisenhower and Richard Nixon. In terms of sustaining and expanding the portfolio of the vice president, Eisenhower too built on what his immediate predecessors had initiated. Naturally this included Vice President Nixon's place in the cabinet and the National Security Council. Nixon was also assigned the chairmanship of an assortment of policy groups and commissions, all of which were established by President Eisenhower. Nixon headed the President's Committee on Government Contracts--aimed at excising racial and religious discrimination by businesses receiving federal contracts--as well as the Cabinet Committee on Economic Growth and Price Stability--from which Nixon helped to coordinate the administration's proactive and reactive economic policies. Ultimately, the expansive administrative tasks assigned to Nixon made his tenure one of substance; helped meet the specific needs of President Eisenhower; and furthered the concept of a utilitarian vice-presidential institution. ${ }^{142}$

After eight years as vice president, Richard Nixon sought and gained the presidential nomination of the Republican Party. Although he failed to win the 1960 presidential election, Nixon unknowingly launched the pattern of incumbent or former vice presidents seeking the presidency. In large part, this came about because of the 
ratification of the Twenty-second Amendment to the Constitution and its imposition of presidential term limits. Although the Twenty-second Amendment, curiously, does not delimit the length of time an individual may serve as vice president; it is, nonetheless, an institutional marker for the vice presidency. By constitutionally constraining the length of tenure of a president, the Twenty-second Amendment inadvertently created an expectation for the incumbent vice president to seek the presidency, when the president they served had no choice but to retire. Again, though Vice President Nixon was unsuccessful in his 1960 quest for the presidency, the dye had been cast.

Richard Nixon and his vice-presidential running mate, Henry Cabot Lodge, were defeated by John Kennedy and Lyndon Johnson. President Kennedy accorded his vice president a relatively meaningful role in his administration. Adding to Johnson's attachment to the cabinet and the National Security Council, Kennedy assigned his vice president the chairmanship of the National Aeronautics and Space Council, and the President's Committee on Equal Employment Opportunity. The preceding presidential commissions were just two of several Kennedy gave Johnson a role in; it was all part of the president's effort to make the vice president useful.

Of course, making the vice president useful to Kennedy did not include making Johnson an integral part of the president's inner circle. Nor did it mean, according to the chief administrator of NASA during the 1960s, that President Kennedy, by giving the vice president leadership of the space program, would not retain for himself "control [of] the agenda of the council, [and furthermore] that he wanted to determine those items on which he would seek and would accept advice." ${ }^{\text {143 }}$ There are certainly limits to how much control over a policy sphere any president will cede to the vice president. 
With the assassination of President Kennedy in 1963, Lyndon Johnson became the eighth vice president to move up to the presidency because of the constitutional provision for succession. Slightly more than a year later, President Johnson and Hubert Humphrey, the man Johnson selected to run for vice president with him in 1964, were inaugurated. From the outset of his own term as president, Johnson continued what was by then precedent: conferring substantive domestic policy assignments to the vice president. This included making Vice President Humphrey chairman of the National Aeronautics and Space Council; the Peace Corps Advisory Council; the Cabinet Committee on Employment, and the Antipoverty Program Advisory Council. If that were not enough, Johnson had Humphrey lead the President's Council on Economic Opportunity, on Youth Opportunity, on Indian Opportunity, on Marine Sciences, and on Recreation and Natural Beauty.

The variety of tasks assigned to Humphrey when he was vice president was impressive; moreover, the scope of responsibilities was emblematic of how far the vice presidency had come in the twenty years since Henry Wallace held the office. Indeed, in the years separating Wallace from Humphrey, considerable change had come to the vice presidency; as a result, by Humphrey's time in office, the vice president was no longer viewed as an interloper in the administration of the executive government. For this reason, Humphrey could meet the obligations assigned to him by the president in a way that Wallace could not. Put another way, Humphrey held a degree of leverage based on the accumulative development of the vice-presidential institution which had occurred in the intervening years, and at the behest of several presidents. By Humphrey's estimation: 
I learned that a Vice President can, through his various coordinating roles, push public policy as a gadfly or a conciliator. So many federal programs cut across cabinet lines that it is imperative that disparate but related parts of government work together. While cabinet members resent others' (including their cabinet colleagues as well as the Vice President) interfering in their departments and are jealous of their own domains, the Vice president at least is elected--and is, in a sense, half a step up. ${ }^{144}$

Lyndon Johnson was a complex individual, and a demanding president to work for: one day he would praise Humphrey for his work on a presidential commission; and the next day, reclaim any authority Vice President Humphrey held over a presidential task force, giving responsibility for formulation and implementation of the specific policy to an another individual or administration entity, instead. Humphrey later summarized the difficulties he had in being Johnson's vice president, stating: "Part of our problems came from the institutions of President and Vice President, part from the uneasy juxtaposition of our two personalities." ${ }^{145}$ Either way, it is the president who determines the effectiveness of the vice president; it is an axiom that holds to this day.

Lyndon Johnson and Hubert Humphrey were followed in office by Richard Nixon and Spiro Agnew. Nixon's motives for choosing Agnew are not relevant to this study, other than to note it was an odd choice and for a brief time the vice presidency, as an effective institution of the government, regressed. ${ }^{146}$ Humphrey, fittingly, encapsulated Agnew's tenure, by juxtaposing it with his own; noting that "whatever the miseries and 
inadequacies of the vice presidency, I had considered it an honored position, and to have been succeeded by Spiro Agnew did not please me."147

Certainly, as vice president, Agnew attended meetings of the cabinet and the National Security Council, and he likewise chaired a variety of commissions President Nixon offered him. Nixon likewise used Agnew as a liaison between the federal government and the city and state governments. But on the whole, Nixon opted to keep his first vice president at a distance; it was an ironic arrangement, in light of Nixon having been one of the earliest practitioners of the modern, utilitarian vice presidency.

Spiro Agnew's resignation from office brought the first use of the Twenty-fifth Amendment. The Twenty-fifth Amendment--detailed in the next chapter--provided a much needed provision for replacing the vice president when a vacancy occurs in the office. To fill the vacancy, President Nixon nominated Gerald Ford for vice president; the formal nomination was then followed by congressional hearings; with the process concluding after Ford was approved by a vote of both chambers of Congress. In sum, the entire process unfolded without the input of the Electoral College; and Ford's nomination was not voted on by the nation's electorate. Ultimately, when evaluating the institutional development of the vice presidency, reviewing Ford's tenure is of limited value. In other words, though Ford took office under extraordinary circumstances, his time as second to Nixon was unremarkable. As it was, Ford was treated with indifference by the president, and his usefulness to Nixon was marginal; he would spend the entirety of his time as vice president in a holding pattern for the presidency.

Obviously, only Richard Nixon knew precisely the extent of his involvement in the Watergate affair. It was therefore impossible to predict how he would respond to the 
pressures of Watergate. But there was one certainty: Nixon's presidency was indisputably doomed in the weeks and months following the onset of the Ford vice presidency. Ford endeavored to balance loyalty to the president who picked him, while making certain he was ready to take over for Nixon if the outcome of Watergate compelled a move to the White House.

To prepare for his probable ascent to the presidency, Ford regularly conferred with Nixon's national security team; he met with members of the Nixon cabinet; and he was kept abreast of the economic and budgeting policies of the administration. ${ }^{148}$ As a consequence, on August 9, 1974, when Richard Nixon became the first president in American history to resign from the nation's highest elective office, Gerald Ford was standing by and set to take the reins of government. Even though the transition of power was seamless, the circumstances under which the transition took place were wholly anomalous. For unlike every other vice president to have made it to the top spot in the United States government, Ford was the first individual in history to make it to the vice presidency, and then to the presidency, without the nation's electorate ever having had an opportunity to vote for or against him.

It was oddly appropriate that among the myriad critical tasks facing President Ford, the first order of business was the selection of a nominee for vice president. Ford committed himself to nominating an individual "fully qualified to step into my shoes should something happen to me." ${ }^{149}$ To meet this goal, aides to Ford reviewed potential nominees for "their national stature, executive experience and ability to broaden...[Ford's] political base, [then] assigned them points and ranked them numerically." ${ }^{, 150} \mathrm{He}$ was then presented with the names of five individuals and their total 
scores. Of those five--including George H.W. Bush and Senator William Brock--Ford eventually settled on Nelson Rockefeller.

Rockefeller was an established national political figure when he was nominated and confirmed by Congress as only the second vice president selected by way of the Twenty-fifth Amendment. It was not manifestly clear why Rockefeller would settle for the vice presidency, but surely the incremental expansion in the scope of power, and in direct responsibilities, of the office of the vice president made the institution of enough substance and significance that Rockefeller was willing to take the job. Quite possibly, Rockefeller was swayed by the development of the institution throughout the twentieth century. $^{151}$

Rockefeller also must have been encouraged that by 1974 the institution had become transparently integrated into the broader operations of the executive branch. Hence, Rockefeller could count on a seat in the cabinet; membership in the National Security Council; chairmanships of a number of high profile commissions, should he so desire; inclusion in the decisional framework for foreign policy and national security concerns; and, initially with Ford's concurrence, as vice president Rockefeller was determined to formulate and implement the administration's domestic policy agenda. ${ }^{152}$

For a time, Vice President Rockefeller was active in the principal policymaking unit in the White House: the Domestic Council. Initially, despite strong opposition from Ford's chief of staff, Donald Rumsfeld, Rockefeller successfully placed one of his own advisers to manage the council, and subsequently claimed the vice-chairmanship for himself. ${ }^{153}$ Yet Rockefeller's triumph essentially ended there. He did put forward a number of ambitious domestic proposals--including a national health care plan and a 
proposal for massive outlays in government loans for independent energy initiatives--but none of the preceding projects was ever implemented. In the main, Rockefeller's efforts leading the Domestic Council were stymied by competitive, and often belligerent, presidential advisers--such as Rumsfeld and, ironically, his assistant Dick Cheney--and therefore it did not take long before Rockefeller's position became untenable, and he eventually chose to resign from the Domestic Council. ${ }^{154}$

President Ford facilitated the development of the vice presidency on several fronts. This included less formal ways than permitting attendance at cabinet meetings by the vice president or assigning the vice president to chair various presidential commissions. During their service together, Ford and Rockefeller commenced the practice of meeting privately each week in the Oval Office; it is a custom every president and vice president to follow Ford and Rockefeller have imitated. ${ }^{155}$ The weekly meetings were initially suggested by Rockefeller, and agreed to by Ford, when they first discussed Rockefeller's expected role in the administration. It was unprecedented to set aside time for the president and vice president to meet alone and the practice gave Rockefeller exclusive and unparalleled access to Ford.

Rockefeller was also appointed by the president to head a commission tasked with comprehensively reviewing the clandestine activities of the Central Intelligence Agency (CIA), specifically on the domestic front. Founded in a similar vein to the numerous commissions and councils typically assigned to modern vice presidents, the Rockefeller Commission had the potential to generate favorable attention for Rockefeller, and it was likewise perfectly suited to the vice president's considerable skills as a public administrator. 
Unfortunately for the vice president, during much of the time the Rockefeller Commission spent fulfilling its charter, there were two ongoing congressional inquiries into the CIA, as well. The Church Committee in the Senate, and the Pike Committee in the House, not only matched the Rockefeller Commission's mission, but both of the congressional panels were afforded sweeping investigatory powers that went well beyond those given to the vice president. After devoting considerable time, as well as conducting a specific and comprehensive analysis of the CIA, the Rockefeller Commission released its final report to negligible effect. ${ }^{156}$ Still, having the president confer authority to the vice president to lead such a high profile endeavor reinforced the perception of an office of the executive branch that could no longer be ignored. More specifically, if Rockefeller's work on this front was to a certain extent outdone by the dual congressional investigations into the CIA, the notion of the vice president having a charter on par with the national legislature spoke volumes.

Even if Rockefeller failed to fully realize his vision of a vice president charged with formulating and advancing domestic policy, at the end of the day he could take consolation in his role as a respected confidant to the president. Besides his regular private meetings with the president, Rockefeller was integrated into all national security deliberations, and Ford valued the vice president's advice on a number of critical problems he faced while in office. ${ }^{157}$

When Gerald Ford decided to try and get elected to the presidency, he moved forward without Nelson Rockefeller. The reasons Ford opted to select Senator Bob Dole, instead of Rockefeller, are complicated and not germane to this study. ${ }^{158}$ It should suffice to state here that Ford later described his own behavior as "cowardly," and Henry 
Kissinger stated categorically that "dropping Rockefeller still strikes me as the single worst decision of Ford's presidency." ${ }^{159}$ Regardless, the Ford-Dole ticket went down to defeat and Jimmy Carter and Walter Mondale were installed in the presidency and vice presidency, respectively.

In every respect, President Carter was responsible for allowing the significant form the Mondale vice presidency eventually took. But befitting the nature of the partnership Carter and Mondale forged from the outset; Mondale too was responsible for engineering the direction in which the institution moved. To this end, and at Carter's request, in the days after their victory, Mondale prepared a set of proposals for making the vice presidency meaningful. ${ }^{160}$ According to Mondale, the proposal he offered Carter was "historic...Nothing like it had ever been done before, and it led to a redefinition of the vice president in modern American government."

In trying to rectify many of the inadequacies that plagued the vice presidency since its inception, Carter and Mondale first had to confront the principal, intrinsic contradiction of the institution. As Mondale described it, "the only role the Constitution assigns the vice president is to preside over the Senate and break a tie when necessary. In a strange way, since the vice presidents were in both branches, they historically had been treated as though they were in neither."162

Induced by the strength of Mondale's blueprint, Carter was resolute on the vice president being "truly...the second in command, involved in every aspect of governing." ${ }^{\prime 63}$ This, by Carter's interpretation, meant Mondale "received the same security briefings... was automatically invited to participate in all...official meetings, and helped to plan strategy for domestic programs, diplomacy, and defense."164 
On the whole, Mondale did not encounter challenges to his authority from within the White House. Carter let Mondale select personnel for several key positions; including prime postings on the National Security Council and the Domestic Council, as well as in the Office of Management and Budget. Mondale's success on this front is noteworthy; as it then became a reasonable expectation that vice presidents would bring a fair share of staffers whose loyalties lay more with the vice president than with the president. Additionally, Carter facilitated the assimilation of Mondale's staff with his own; making the vice president's staff, both in theory and in practice, equal to the White House staff. There was a caveat, as Mondale pointed out, in that "all of this would merely have been symbolic if I didn't have a concrete role backed by the president." 165

Because presidential elections have always been most about the candidates for president, and not the candidates for vice president, the transformative success of the Mondale vice presidency was not enough to reelect the Carter-Mondale team. Instead, Ronald Reagan and George H.W. Bush were elected. Reagan, having served as a governor, came to the presidency with state executive experience; whereas, Bush brought an array of government experience to the vice presidency: congressional representative; ambassador to the United Nations; chairman of the Republican National Committee; chief of the Liaison Office in Beijing, China; and director of the Central Intelligence Agency.

After the election, and following the example set by Walter Mondale, Bush played a role in staffing, naturally, the office of the vice president; but he also weighed in on several key postings at the White House. Among the first placements Bush engineered was the appointment of his close friend and adviser, James Baker, as Reagan's first chief 
of staff. With Baker situated atop the White House staff, Bush had an individual he implicitly trusted, probably more than any other when it came to politics, as overseer of the very people who might otherwise undercut the vice president. Baker's presence, coupled with the vice president's private office near the Oval Office, gave Bush a solid foothold inside the White House.

Beyond the assignment of key administration staff, Bush had an added edge when he took office. Since Jimmy Carter and Walter Mondale had worked so diligently at enhancing the vice-presidential institution, Reagan and Bush inherited a changed executive dynamic; the question then became whether they would replicate some, all, or nothing of the Carter-Mondale model. But with the evident dichotomy in Reagan and Bush's strengths and weaknesses, it was prudent to capitalize on the strides already taken by Carter and Mondale. Surely Reagan benefited from following Carter's lead since he, like Carter, lacked experience in the national government. In making his vice president a utilitarian figure in the administration, as Carter had done before him, then Reagan could relieve, to a certain extent, some of the burdens of leading the executive branch.

Along these lines, Reagan insisted Bush chair meetings of the National Security Council when he was absent. And, by continuing what President Carter started, he helped to institutionalize the placement of the vice president as the second in the military chain of command. Each of the practices just listed transparently signified the vice president's presence in the executive branch. Furthermore, there was a genuine value in confirming that the vice president was prepared to step in for the president whenever, and wherever, necessary. 
Reagan also sanctioned a broad portfolio of substantive duties for Bush; including his use of the vice president as coordinator of different federal organizations simultaneously combating the importation of illegal drugs into the country. This was a way to use the office of the vice president to manage disparate bureaucracies, all which were engaged in a similar mission, but with no synchronization between the groups. In this area, Reagan used the visibility of the modern vice presidency to emphasize the importance he placed on fighting the drug war, as well as to centralize command of the project. In doing so, Reagan was using the vice president in a similar fashion to that of Franklin Roosevelt and his use of Henry Wallace during the Second World War.

Bush was also put in charge of two distinct task forces: one was meant to oversee the deregulation of an assortment of programs administered by the federal government; the other was tasked with minimizing government regulation of business and industry. With the latter, Bush was subsequently given high marks for his work in this area, and in a telling gesture of the value he derived from the project, he later assigned the same mission to his own vice president. Likewise, in a move that appeared perfectly in line with conventional notions of the modern vice presidency, President Reagan resolved to further extend Bush's presence in the affairs of national intelligence and security. Appended to his original decision on the vice president chairing meetings of the National Security Council when he could not be present, Reagan installed Bush as the head of a newly formed crisis management team--in essence, an extension of the National Security Council.

For the sum of his vice presidency, George Bush epitomized the administrator as vice president, going about his work, generally unnoticed. In his effort to move from the 
second executive to the chief executive, he ran as the most experienced and therefore, presumably, the most qualified candidate for president. With his eight years as the vice president being the longest he had stayed in any government job, Bush could justly point to his own activist tenure, in the service of an often disengaged president, as the necessary preparation for him to have the top job. Bush's argument was simple: since his was a meaningful vice presidency, then he was better prepared for the presidency than any opponent of any political party. This argument worked: first, within the Republican Party, and despite the lingering reservations many conservatives held toward him; and then later, in the general election against the Democratic nominee for president. It also worked irrespective of his choice for vice president: Senator Dan Quayle.

The travails of Dan Quayle in the campaign of 1988 are better dealt with in other studies. ${ }^{166}$ It is enough to note here that a series of verbal gaffes, and a less than stellar performance in the single televised debate of the vice-presidential candidates, colored popular opinion of Quayle for the entirety of his vice presidency, and beyond. But if Quayle misspoke on too many occasions, when he was the vice president he was never derelict in the conduct of his duties or in fulfilling specific assignments given to him by President Bush.

In retrospect, Quayle would cite his work chairing the Council on Competitiveness and the National Space Council as especially noteworthy facets of his vice presidency. ${ }^{167}$ For the Council on Competitiveness, Quayle managed a federal task force charged with minimizing, and whenever possible eliminating, government regulation of business. To do this, Quayle was given authority to intercede before federal regulations were issued, modifying the regulations to suit the agenda of the 
administration. According to some, this method violated the law requiring standard procedures, including the availability of a forum for public comment for all proposed federal regulations. ${ }^{168}$

The advantage for Quayle was the outcome of the work of the Council on Competitiveness, by-and-large, was a boon for the business community--not coincidentally, a traditional constituency of the Republican Party. As a consequence, Quayle was able to foment increased deregulation of industries and businesses that could potentially underwrite a future presidential run by the vice president. In this way, the accumulation of executive, administrative authority and functions established within the institution over time, provided the vice president, irrespective of who held the office, the framework from which to build a substantive record that stood somewhat apart from the incumbent president. And of greater consequence to those who held the second office: the expectation for vice presidents to administer various presidential commissions and councils, furthered the notion of the vice president as heir apparent.

The prospect for earning political capital was a bit less promising with the Space Council than it was with the Council on Competitiveness, but undeniably there were opportunities to profit from the American public's long-time infatuation with space exploration. Hence, Quayle eagerly approached the government's space program, attempting to streamline the bureaucracy of the National Aeronautics and Space Administration (NASA), thus making it more economical in the process. In this vein, Quayle directed, via the recommendations of the Space Council, a change in the top echelon of administrators at NASA, which subsequently led to a fundamental rededication of the agency's intuitional mission. 
Regardless of the broadly held view that Quayle was ill suited to serve as vice president, let alone president if circumstances called for his ascension to the presidency, he benefited from the many precedents established during the vice presidencies of Nelson Rockefeller, Walter Mondale and George H.W. Bush. Recognizing that his job was much easier because his immediate predecessor was Bush, Quayle later remarked that he "had the good fortune to work with a former vice president."169 As such, Quayle's experience was relatively unique: in the two hundred years preceding his tenure, only eleven of the forty-three individuals to precede him in office could say the same. And of that eleven, few if any could have honestly claimed, as Quayle could, to have been treated with a modicum of respect by the president under whom they served.

\section{$\underline{\text { Shifts in the President-to-Vice President Arrangement }}$}

The American electorate turned President Bush and Vice President Quayle out of office in 1992. For Bush it meant that even though he was the first vice president since Martin Van Buren to go directly from the vice presidency to the presidency; he had merely matched Van Buren, again, in not winning a second term in the White House. As for Quayle, even if the vice presidency represented both the apex and the end of his political career, from his first day in office he was the beneficiary of years of precedents, as well as increased visibility for the vice presidency which, in turn, had made for a more stable and substantial political institution. It was appropriate then, that the candidates who defeated Bush and Quayle--Bill Clinton and Al Gore--would bring a new approach to executive governance that thoroughly integrated the office of the vice president with that of the president. 
Accordingly, as the last decade of the twentieth century unfolded, Al Gore took the helm of a vice-presidential office unmatched by prior manifestations of the office--in stature, resources, and influence--and then, with the acquiescence of President Clinton, Gore proceeded to bring the vice presidency nearer to equipoise with the presidency. On the whole, this came about as a result of the shift in the way Clinton and Gore worked together, and which was so blatantly dissimilar from the working relationships of presidents and vice presidents to have come before. For as the vice presidency developed over time, and regardless of how accommodating the incumbent president was, there was one constant: the president-to-vice president relationship was a vertical, hierarchical arrangement--transparently oriented from the president down to the vice president.

With the commencement of the Clinton-Gore era, the traditional arrangement flipped; instead structuring it closer to a horizontal, hierarchical setup. It should be understood, however, in no way was there any blurring of the line of final authority--that would come, arguably, with the president and vice president who followed Clinton and Gore--but the consensus was that Clinton would have the final say, contingent on the vice president having weighed in, as well. To this point, it has been suggested President Clinton never made a "major policy decision...without discussing it with the vice president. ${ }^{, 170}$

When taken together, the outcome of the Clinton-Gore partnership was a modern vice-presidential institution, actualized beyond any notions the Framers of the Constitution may have held for the second office of the land. Besides, it is unlikely any of the Framers could have envisioned a president and vice president maintaining the degree of equilibrium in their association, as Clinton and Gore did. And yet, in light of the 
exponential growth of the American presidency over the course of the twentieth century, it made sense for the vice presidency to approximate keeping pace with the higher office.

On every account, Gore was the appropriate fit for the vice presidency at that juncture in the trajectory of the institution's development. Of course, he benefited immensely by serving a president who chose to extend, and not retract, the prerogatives the office had accrued. To his credit, Gore sustained the required balance of deference and influence with President Clinton, consistently making his political and policy ambitions secondary to those of the president. On any number of occasions he avowed to heed an unassuming, yet straightforward credo: do whatever necessary to achieve the goals of the president and, in the process, help to ensure Clinton was, in Gore's words, "the best" president. ${ }^{171}$

Warren Christopher, who conducted the vice-presidential nominee search for Clinton, and afterwards served as secretary of state for the first term of the Clinton administration, offered one of the better observations on the shared Clinton-Gore tenure: The partnership that began so auspiciously continued throughout my time in office. The way they worked together raised the office of vice president to a new level of public awareness. Gore became a full partner, not because Clinton made a formal commitment to make it so but because the president genuinely respected Gore's views and talents. They enjoyed each other's company, teasing and laughing in a natural way that bespoke friendship rather than a number one/number two relationship. Time and again, I found that the president made his most important decisions only after talking privately with the vice president. 
Clinton's mantra--'It's all right with me, but let's talk it over with Al before we decide'--became familiar to every member of the cabinet. ${ }^{172}$

The effect of the Clinton-Gore association went well beyond the immediacy of their two terms in office; instead, the model Clinton and Gore established would extend the president-to-vice president construct. The result of this was, depending on one's point of view, positive; however, a feasible argument could also be advanced that, ultimately, what Clinton and Gore initiated went too far--in setting precedents, while creating an opening for potentially unwanted outcomes for the vice-presidential institution, as well as to the model for executive governance. The advantage in how Clinton and Gore operated together was realized by the way executive responsibilities, as well as lines of authority, was shared. The answer to why this matters is deceptively simple: the American presidency of the twentieth and twenty-first centuries has become, without doubt, too much for one individual to manage.

Although there are myriad examples of Al Gore's involvement in the administration of the executive branch, in the eight years he was vice president there was no project that defined his tenure to the extent the reinventing government initiative did. Formally instituted in March of 1993 by President Clinton, the National Performance Review was led by Gore and commissioned to identify ways to streamline the federal government; specifically with regard to management, personnel, procurement and budgeting. And though the project was clearly not as contentious as others advanced by the Clinton administration, it proved to be a success on several accounts. ${ }^{173}$ 
Gore was the best choice for this assignment for a number of reasons, not the least of which was because the project was intended to be a prominent feature of the Clinton administration's maiden agenda. By signing on to the initiative, Gore was set to increase his own political capital, as well as that of the administration; moreover, in the process he would broaden the portfolio of the vice president. This latter point is especially salient in that each instance when the purview or resources of the vice presidency have increased, each then becomes an established prerogative for the institution, and consequently moves forward to the advantage of the next occupant of the office.

Naturally, any new president may decide not to extend the same responsibilities and assignments to the vice president they came to office with; and the president could even retract all the duties of the preceding vice president, apart from those prescribed by the Constitution. For that matter, the president could prompt, with the collaboration of willing members of Congress, legislation aimed at repealing earlier statutes granting the vice president specific prerogatives--like the vice president's permanent place on the board of the Smithsonian Institution or membership on the National Security Council-although pursuing such a course would be highly irregular, and somewhat suspect. In addition, when presidents have facilitated an expanded vice-presidential institution, the fundamental dynamic of the president-to-vice president relationship has been profoundly, and maybe even permanently, altered.

Returning to the National Performance Review initiative and Vice President Gore, specifically, of the many pledges made by the Clinton-Gore ticket during the 1992 campaign, prominent among these was a commitment to reducing the size and inefficiency of the federal government. To reconfigure the federal bureaucracy, per se, is 
a daunting proposition, though it is unlikely to raise the ire of most observers, and thus it could be viewed as an attractive undertaking for a rising political figure. Furthermore, having one half of the victorious electoral ticket spearhead the initiative lent distinction to a project that in all likelihood would be a boon to the Clinton administration, as well as to the vice president.

There was no uncertainty about Gore's suitability for the project. On the whole, he was atypical for a politician, in that he had always been comfortable immersing himself in the minutiae of politics and policy; it was no different for him when it came to reorganizing the federal bureaucracy. Gore was fine with non-glamorous tasks, working in the shadows, as it were; ironically, it was a rare trait he shared with his immediate successor, Dick Cheney. Nonetheless, on a tangible level, and in pursuit of the agenda of the National Performance Review, Gore took the vice presidency further into the cabinet by his interaction with, and dictates to, each cabinet secretary. This entailed the vice president's coordination of every department and agency in the federal government--from the leadership, to countless midlevel public administrators--all with the intent of microevaluating, and then overhauling, every organization therein.

The outcome of Gore's effort was impressive: 100,000 federal government jobs were eliminated; federal regulations which had taken 16,000 pages of the Federal Register to delineate were made obsolete; and 10,000 pages from manuals for federal employees were discontinued. ${ }^{174}$ And there were additional, equally noteworthy results. Later, Bill Clinton lauded the work of the vice president on this front; claiming the reinventing government project was "developed according to a simple credo: protect people, not bureaucracy; promote results, not rules; get action, not rhetoric. Al Gore's 
highly successful initiative confounded our adversaries, elated our allies, and escaped the notice of most of the public for the reason that it was neither sensational nor controversial." 175

From an institutional perspective, President Clinton's selection of Vice President Gore to lead the initiative reaffirmed the standing of the vice presidency at that point in its history. In choosing the vice president to oversee the reorganization of the federal bureaucracy, of which the president is the chief executive, the place of the vice president was established squarely in the executive branch, thus lessening the ambiguity on what branch of the government the institution belonged to. Furthermore, the vice president's connection to the executive has been strengthened, to a certain extent, because the link between the vice president and the legislative branch has been weakened over time. Quite simply, this has transpired because the Constitution assigns two specific functions for the vice president to carry out--preside in the Senate and cast a vote in the chamber on those occasions when there is a tie vote amongst the members of that body--and yet, the vice president rarely does either.

With regard to the vice president breaking ties in the Senate, the data indicates there is rarely cause for its use. For example, during their terms as vice president, modern occupants of the office--such as Calvin Coolidge, Lyndon Johnson, Gerald Ford, Nelson Rockefeller, and Dan Quayle--were never called upon to cast a tie-breaking vote. ${ }^{176}$ And while John Adams broke twenty-nine ties in his eight years as vice president; Dick Cheney was called on just eight times to do the same. ${ }^{177}$ To be certain, the broader political environment, coupled with the partisan composition of the Senate influences the frequency for which the vote of the vice president is needed. Then again, a plausible 
explanation might be that the modern American vice presidency is an institution which has outgrown its constitutional place in the government.

The inference here is not of the vice president's role in the legislative branch being incrementally erased by a commensurate increase in responsibilities in the executive government; nor could it, as presiding in the Senate was precisely where the Constitution sanctioned the vice president to be. But giving the vice president vast administrative oversight--which certainly was the case with Vice President Gore and the National Performance Review--confirmed the standing the office held within the executive branch.

In the long term, the specifics of the National Performance Review are not nearly as important as was the act of assigning the vice president to lead it. For on top of the accolades Gore's leadership accrued, his work in this area expanded on the concept of the vice president as public administrator. This was an auxiliary, but vital, outcome of Gore's success with the reinventing government project, as it contributed considerably to the form and substance of the vice-presidential institution. Why this mattered was simple: the imprint Gore left on the institution was sure to carry forward. Therefore, if history was indeed a reliable indicator, and previous augmentations to the institution did not occur in a vacuum, Gore's successors were bound to take over a substantial, multi-layered vice presidency.

Al Gore's achievements as vice president have scarcely been recounted here; but for the purposes of this study, why Gore matters is the influence he exerted on the vice presidency as an institution of the executive government. It was not that he was remiss in fulfilling the constitutional duties of the vice president--presiding over the Senate, and 
voting in the event of a tie in the chamber--because when he presided, he did so ably. But in eight years he was called on to cast just four tie breaking votes; so it is a fair assumption his presence was not essential in the day-to-day working of the Senate, nor was it ever expected to be. ${ }^{178}$

Yet in making the institution better and more complete, Gore helped make it indispensible. He had, by President Clinton's estimation, “a larger role substantively and more influence than any" of his predecessors ever had. ${ }^{179}$ Working in unison, Clinton and Gore found a way to build on the template for a substantial president-to-vice president arrangement, the outline for which was first suggested by President Ford and Vice President Rockefeller; extended and practiced by President Carter and Vice President Mondale; and then facilitated by each succeeding president, thus making it the norm for every president-vice president team to follow.

All things being equal, Al Gore very well may have been the ideal vice president; yet, the source of his power and prestige--President Clinton--may have hampered Gore's own rise to the presidency. The predicament Gore found himself in was neatly framed, nearly forty years earlier, when President Johnson had told an eager Hubert Humphrey that, by taking on the position of Johnson's vice president, their relationship would be analogous to "marriage with no chance of divorce."180 Johnson may have been overstating his case, but, short of resignation, impeachment, or death, Humphrey really had no way out; he would forever be Johnson's vice president. In much the same way, Gore was bound to Clinton--for better or for worse.

When accounts of the Clinton era are written, it will always be in the context of President Clinton and his successes and his failings. The irony here is this: as the vice 
president for eight years, Al Gore will share the burden of Clinton's legacy, good and bad, but the partnership he forged with Clinton, and the contributions both made to the institutional vice presidency, will be largely overlooked. For Gore, it is an unfortunate outcome of his never having made it to the presidency; for it is the presidency that is remembered, rarely the vice presidency. Perhaps of most consequence, though, is that Gore's concerted elevation of the office of vice president prepared the foundation for the ascension of perhaps the most powerful vice president to date.

The anomalous presidential election of 2000 resulted in Al Gore's failure to move from the presidency to the vice presidency. The dynamics informing that outcome will undoubtedly be debated well into the future. Certainly serving as vice president for eight years had established Gore as a national political figure, and his service was likely a factor in his gaining the presidential nomination of his party. Apart from the extenuating electoral machinations of the 2000 election, however, there was no precedent that serving in the modern vice presidency was an assured path to the presidency. Perhaps what is most ironic about an election beset by irony is that, in not winning the presidency, Gore was succeeded in the vice presidency by an individual determined to take the institution further into the executive branch than ever before.

\section{The Vice Presidency Reaches A Measure of Symmetry With the Presidency}

After George W. Bush and Dick Cheney defeated Vice President Gore and his running mate, Senator Joe Lieberman, Cheney followed the course set by his most recent predecessors and helped set what form the new administration would take. Cheney, however, took this role a step further than had any other vice president-elect, becoming the chief coordinator of the transition of power from the Clinton administration to an 
impending Bush administration. This was unprecedented on two accounts: never before had a vice-presidential candidate, in the throes of a contested election, assumed to be the victor before the Electoral College had met and voted. And second, it was anomalous for a candidate for vice president to oversee an enterprise as vast as the transition from one government to another. Cheney's assumption of control, and his subsequent vigorous exercise of authority, eventually distinguished all dimensions of his vice-presidential tenure.

It was in the midst of the transition period that Cheney shrewdly set in motion the assimilation of the vice presidency into the presidency. This was a different product of the Bush-Cheney association than has been suggested elsewhere. For instance, recently it has been argued that what Bush and Cheney implemented was analogous to a "copresidency." ${ }^{\prime 181}$ This proposition is problematic because the term co-presidency implies presidential powers are divisible and shared executive governance is feasible. For that matter, where political systems are concerned, examples of legitimately shared, or collegial, executive arrangements are few, nor enduring. ${ }^{182}$ Of necessity, all plural executive arrangements are characterized by countervailing dynamics with one executive having a modicum of an advantage over the other; were it not so, definitiveness on policy questions would routinely be elusive.

As a practical matter, hierarchical arrangements are just that--hierarchical--and thus top-down arrangements are necessary to reach, if not consensus, conclusion. Granted, in a presidential system, like the one found in the United States, and which has a trifold balance of power, the executive is subject to specific veto options delegated to the legislative and judiciary by the Constitution. ${ }^{183}$ The caveat here is that over time the 
American presidency has unquestionably gained strength at the expense of the legislative and judicial branches of the government; thereby, diminishing some of the efficacy of the checks the two countervailing branches hold on the executive branch. Then again, in acknowledging the checks of the national legislature, and of the judiciary, with no less than the Supreme Court atop the latter branch, the president has commensurate checks on each, compounded by the legitimacy of being elected nationally--a claim no other officer in the system, besides the vice president, is justified in making.

Yet, in the midst of a transition of his making, Dick Cheney did claim to be legitimately elected, if not by a majority of the nation, then with enough evidence to satisfy him. And when the outcome of the Supreme Court's intervention in the 2000 election was announced in his and George W. Bush's favor, Cheney worked the opportunity he was given, taking his new executive position past notions of a shared presidency. In retrospect, it appears Cheney was bent on absorbing control of the transition from the president-elect--specifically in terms of filling cabinet posts, as well as top-level positions responsible for formulating the domestic and foreign policy agenda of the impending administration--all the while knowing it would set the tenor of the ensuing four year term. ${ }^{184}$

In deconstructing the outcome of Cheney's plan, it is immediately clear that what he had achieved was remarkable. He had succeeded in blurring the divide between the president and the vice president, as well as the respective formal organizations that heretofore separated the two institutions. Hence, the vice-presidential and presidential institutions coalesced and took the form of a single political institution with, in theory, two executive officers elected concurrently. 
When evaluating Cheney's actions on this front, it is important to recognize the vice presidency continues to be viewed by the broader electorate as a sinecure filled by politicians who were not of presidential caliber, but who would be fine as the vice president. What Cheney accomplished, with Bush's compliance, was to take an institution like the vice presidency--which had benefited from precedent and statute and likewise had acquired abundant institutional resources--and integrate that institution into the presidency, while making himself fairly indispensible to the president he was elected to serve under.

Dick Cheney's influence on the policies of the Bush administration should not be understated; his influence was vast and crossed into all policy genres. In order to narrow the scope of inquiry for the purposes of this study, evaluation of Cheney's role in one specific realm of policy is most efficient and likewise indicative of his influence across the board. When Cheney arrived in the vice presidency, he was incontrovertibly determined to initiate new government policies; yet his drive towards new policies was consistently in conjunction with vigorous movement towards deregulation of the existing practices of the government. And more times than not, there was an ancillary goal of clearing the way for unfettered commerce. In no policy sphere was this more apparent than with Cheney's consistent intercession on behalf of those corporate interests impacted by the environmental policies of the federal government, in particular, the regulation of energy resources.

For the most part, Cheney's involvement in formulating a national energy policy escaped the attention of the public. Perhaps Americans were simply becoming accustomed to activist vice presidents. All three of Cheney's immediate predecessors had 
been engaged on multiple fronts, although they had more impact in certain areas than they did in others: Walter Mondale in foreign affairs; Dan Quayle with the Competitiveness Council; and $\mathrm{Al}$ Gore and the reinventing government initiative, as well as an activist role in foreign policy. But Cheney exercised greater and wider influence on the formulation of government policy than any vice president before him. The difference, however, was Cheney never appeared to relish the spotlight, as had Mondale, Quayle and to a lesser extent, Gore. Frankly, it seemed that Cheney preferred to work in the shadows. In many ways this was fitting, since from its inception the vice presidency always seemed a shadow institution, with the presidency forever the more tangible of the two.

When Dick Cheney first ran for vice president, he bemoaned the lack of a national energy policy. He liked to lay blame on the Clinton-Gore administration for what he saw as too much restraint, specifically when it came to expanding the domestic production of oil; it was a point he made repeatedly on the campaign trail, as well in his debut appearance in a vice-presidential debate. Although Cheney preferred to deliver speeches to friendly audiences, in out-of-the-way venues, the two vice-presidential debates he participated in--one in 2000; the other in 2004--provide scattered, yet invaluable glimpses of his beliefs and of his attitude. Simply put, since the single debate held for vicepresidential candidates has become a staple of presidential campaigns, Cheney had little choice but to participate. The debates therefore represent the two times in eight years that he was compelled to abandon his steadfast reticence and, in turn, publicly answer questions.

Throughout the first vice-presidential debate, Cheney exhibited the singlemindedness that would characterize his behavior for the whole of his tenure; offering 
curt, unequivocal responses on complex topics. For instance, when asked about the fluctuations in oil, natural gas and electric prices, and how the government, in allowing market instability, was not doing enough to protect the American people, Cheney briefly delineated the failure of the Clinton administration to foster energy production in the United States, and then concluded by suggesting “it's important that senior citizens don't suffer this winter, but we need to get on to the business of having a plan to develop our domestic energy resources in producing more supplies." 185 It was a terse and not too subtle indication that expanding the business of energy production was a priority for the prospective vice president--irrespective of the impact on senior citizens.

In retrospect, Cheney's comments in the vice-presidential debate do not seem especially noteworthy, since his subsequent actions on energy policy--specifically his chairmanship of the National Energy Policy Development Group (NEPDG)--are now, in part, public record. Fittingly, the task force devoted to creating the Bush administration's energy policy came to symbolize the Cheney vice presidency in its entirety: the expansion of executive power; the collusion of government and business; and the complete, imposing, and unprecedented presence of the vice president.

Nine days after Dick Cheney took the vice-presidential oath of office, NEPDG was established by President Bush. Almost immediately referred to as Cheney's task force on energy, the group was instructed to formulate "a national energy policy designed to help the private sector, and government at all levels, promote dependable, affordable, and environmentally sound production and distribution of energy for the future." ${ }^{186}$ In addition to the vice president, the task force included four senior officials of the Bush 
administration; nine cabinet-level officials; assorted support staff; an interagency working group; and public administrators from various federal agencies. ${ }^{187}$

There was a parallel group of individuals who met with Cheney about the direction of the administration's energy policy, and who were never accounted for in any organizational chart. The composition of these unofficial counselors to the vice president, and the extent of their influence in the formation of the administration's energy policy would in time become one of the more mysterious elements of the inner workings of the Cheney vice presidency. For the vice president to meet with a group of energy industry leaders, along with other government officials, was not surprising, nor unusual. After all, Cheney had been a chief executive of a major corporation immersed in the business of energy. The president too had worked in the same industry, though the vice president was markedly more successful when he was in the business world, than was his boss.

Poles apart from his mid-1970s approach to policy formulation in the executive branch--when he worked with Donald Rumsfeld to undercut Vice President Nelson Rockefeller and the Domestic Council, and to obstruct the vice president in the formulation of public policy for the Ford administration--by 2001, Dick Cheney was determined to keep matters of policy within the vice president's office. There was no need for a Domestic Council, per se, as the vice president, and those working closest to him, kept their own counsel. And because President Bush by most accounts appeared disengaged with the details of governance, Cheney had no need to wrest control of the public policy agenda from the president. ${ }^{188}$

But what made Cheney's actions with the energy task force apropos to a broad review of his vice presidency was that all the components underlying his theory of 
executive preeminence coalesced. This included the vice president holding meetings on the nation's energy policy in secret and with anonymous attendees; the assertion of executive privilege for the vice president, thus setting precedent; the cooptation of cabinet secretaries, in this case affecting those individuals heading the Department of Interior and the Department of Energy; and challenging the principle of congressional oversight, therefore repudiating the system of checks and balances implicit in the United States Constitution. ${ }^{189}$

In the end, Dick Cheney managed to build on the precedent of presidents tasking vice presidents with policy portfolios; he then made that particular institutional marker more germane to executive governance. Indeed, with the National Energy Policy Development Group, Cheney achieved the outcome which had informed his every move when he was vice president: he had helped to reinvigorate the power and preeminence of the executive in the American constitutional system. ${ }^{190}$ More importantly, he had achieved this from his place in the office of the vice president. 


\section{Institutional Development by Constitutional Directive: The Twenty-fifth}

\section{Amendment}

"No second-rater ever ought to be nominated for Vice-President."191

(Vice President John Nance Garner)

Unquestionably, presidential succession and those instances of the incapacitation of the incumbent president were problematic, and had been since the establishment of the nation. At the same time, vacancies in the vice presidency were consistently an auxiliary concern; although, concern is too strong of a descriptor for the reaction to those occasions when the second office fell vacant. As was demonstrated by the earlier review of the string of succession laws, the Congress, in tandem with specific presidents, repeatedly confronted the equivocation they found on the subject within the Constitution. And though the Constitution did offer some direction for filling presidential vacancies--and Vice President John Tyler seized on the first opportunity to test it--the Constitution offered no guidance for replacing the vice president, should the vice president die, resign, be impeached, or succeed to the presidency. Naturally, the main worry was not about filling the vice presidency so that the duties of the office could be satisfied; instead, the anxiety came from the absence of a ready successor, should a vacancy in the presidency occur.

With the deaths of Franklin Roosevelt and John Kennedy within eighteen years of one another--making the pair the seventh and eighth incumbent presidents to die-presidential succession was becoming an inescapable facet of the American political system. Moreover, with Roosevelt's death occurring when the United States was involved in a world war; and with Kennedy's assassination happening suddenly and 
violently, and in the shadow of a nuclear showdown with the Soviet Union, the necessity in having a vice president in place to succeed to the presidency could not have been clearer. The vice presidency could no longer be neglected, nor could the office be left vacant for years at a time.

It was therefore in a climate of fear and uncertainty when the first steps were taken toward the enumeration of an orderly, constitutional method for managing presidential succession, as well as for handling scenarios when the president is incapacitated; and finally, for filling vacancies in the vice presidency. This all came about when Senator Birch Bayh of Indiana introduced Senate Joint Resolution 139, just twenty days after Kennedy was killed; it was the precursor for what eventually became the Twenty-fifth Amendment to the United States Constitution. ${ }^{192}$

After countless hours of congressional debate; obtaining the support of two-thirds of both chambers of Congress; and gaining passage by three-fourths of all the state legislatures in the nation; the Twenty-fifth Amendment was ratified on February 23, 1967. The Twenty-fifth Amendment unequivocally demarcates presidential succession, declaring in the first section that should the president be removed from office, die, or resign, "the Vice President shall become President." ${ }^{193}$ Finally, any residual ambiguity on the vice president rightfully succeeding to the presidency was put to rest.

In the third and fourth sections of the amendment, the framework for handling presidential inability is delineated; including provisions for when the president may declare an inability exists, or the vice president and a majority of the cabinet asserts the same about the president's condition. Under either circumstance, the vice president assumes the presidency and "the powers and duties of the office as Acting President" 
until it is confirmed by the president, vice president, and the cabinet, that an inability no longer stands.

One scenario the succession provision of the Twenty-fifth Amendment does not directly address is managing the remote possibility of a double-vacancy in the executive offices--though the absence of direction made sense. If it should occur, the Presidential Succession Act of 1947 would take effect. Under the Succession Act, the Speaker of the House of Representatives is the first in the line of succession, meant to discharge the duties and responsibilities of the president, for the remainder of the current presidential term, and until an election is held. ${ }^{194}$

It was the second section of the Twenty-fifth Amendment which was put in practice twice in the 1970s. That section defines how vice-presidential vacancies are to be filled, giving the president the power to "nominate a Vice President who shall take office upon confirmation by a majority vote of both Houses of Congress." Obviously this gave the president a strong hand in choosing a potential successor and, assuming the vice president served ably and without scandal, aided that individual in gaining a future presidential nomination.

Additionally, by granting the president the means for choosing a replacement vice president, the political party in control of the executive branch had a better chance for maintaining control. Without fail, the earlier debates on the different succession laws gravitated to an unwelcome prospect. If the vice president was to succeed to the presidency and then die, resign, or be removed from office, and the opposition party was in control of Congress, then the will of the majority of the voters would be overturned. 
More challenging than having the political party that lost the presidential election taking over the executive branch via succession, however, was the selection of a replacement vice president, essentially by presidential fiat, and devoid of the direct consent of the voters. Such a process created, as Arthur Schlesinger Jr. once noted, "a unilateral presidential appointment subject to congressional confirmation." ${ }^{195}$ Hence, if the Twenty-fifth Amendment solved, among other concerns, the quandary of filling vacancies in the vice presidency, it does so by a method that is outwardly contradictory to the spirit of democratic ideals. Then again, the argument is not easily made that presidential selection has ever been dictated by democratic ideals. Either way, in order to rectify that flaw in the amendment, again turning to Schlesinger, the simplest way would be to "adopt a constitutional amendment abolishing the Vice Presidency, an office that has become both more superfluous and more mischievous than Hamilton could have imagined....and then provide for the succession...through a congressional statute reestablishing the principle of special presidential elections." 196

The alternative to vice-presidential succession--special presidential elections-would provide a valuable dose of direct participation by the electorate; yet, this method does not account for the immediacy of succession. In other words, succession by the vice president to the presidency has occurred--eight out of nine times--because of death. The ninth instance of succession came about when President Richard Nixon resigned from office, following a protracted struggle by Nixon to remain in office. Aside from the Nixon case, as well as the lengthy death watch following the shooting of President James Garfield, the circumstances prompting succession have been abrupt. What matters then is 
that each instance when the vice president has succeeded to the presidency, regardless of the alacrity of events, the transition of power has been seamless.

Here too the sagacity of the Framers is evident in that succession was provided for at all, even if imprecisely. The powers of the presidency, absent a president, were meant to devolve to the vice president, and such powers were to rest with the vice president, until an election for president was held. It was James Madison who, at one point at the Federal Convention, suggested drafting alternate wording for how and when to fill such vacancies. Madison's disquiet was based on the absence of any provision for “an intermediate election" to choose a new president. Madison won his point, but the wording of that part of the Constitution was indefinite. Was the vice president meant to serve as president until the traditional quadrennial election was held? Or was Congress meant to determine a date and time for an intermediate presidential election? Over the years, when presidential succession was prompted, and the vice president was compelled to fulfill the remainder of the president's term of office--thus avoiding a rushed, intermediate election-propinquity, continuity, and stability have underscored the entire process.

Finally, the effectiveness of the Twenty-fifth Amendment is patently manifest in the reduction in time the vice presidency remains unoccupied after the office becomes vacant. As supported by the data in Table 1.1, prior to the adoption of the Twenty-fifth Amendment, in 1967, the vice presidency fell vacant on sixteen occasions; and since 1967, the office has been unoccupied just twice. Of the first sixteen vacancies, seven were due to the vice president dying in office; one vacancy came about with the resignation of the vice president; and eight of the vacancies were initiated when the vice president succeeded to the presidency. And of the two vacancies since the Twenty-fifth 
Amendment was adopted, one occurred when the vice president resigned; and the second vacancy was prompted by the resignation of the president, and the subsequent succession to the presidency by the first appointed vice president in history.

Remarkably, prior to the Twenty-fifth Amendment, the vice presidency was regularly left unoccupied for lengthy periods of time. For example, in the nineteenth century the vice presidency was vacated eleven times. Of those eleven vacancies, on five occasions the office remained unoccupied for three years, and of those five cases, three times the office was vacant for almost four years. In addition, two of the vacancies to occur in the twentieth century--both pre-1967, and both due to the vice president succeeding to the presidency--the office went unoccupied for well over three years.

Since the Twenty-fifth Amendment was incorporated into the Constitution, thus providing a methodical means for filling vacancies in the vice presidency, the amount of time the office was left unoccupied diminished precipitously. For instance, when Vice President Spiro Agnew resigned in 1973, merely one month and twenty-six days elapsed from the time President Richard Nixon submitted his choice to succeed Agnew, Gerald Ford, and Ford's confirmation by Congress. Subsequently, when Ford moved from the vice presidency to the presidency, and then named his own successor to the second office, Nelson Rockefeller, there was a vacancy gap of just four months and eight days.

By every measure the Twenty-fifth Amendment has been a success. The time that the office stands vacant has been lessened because the president now has the authority to locate, nominate, and replace the vice president within a brief period. This is important because modern vice presidents are much more utilitarian than vice presidents in earlier eras; indeed, throughout the course of the twentieth century, expectations for the 
executive in the American system have become much greater. The view that both executives of the national government may exercise greater authority and responsibilities is therefore compatible with the idea of extending, by direction of the president, the role of the vice president in executive governance. The outcome of this arrangement is the vice president is of more value to the president, to the administration, and to the nation, than ever before.

The Twenty-fifth Amendment, however, has not escaped criticism. In the mid1970s, one scholar went so far as to claim the "flaws" of the Twenty-fifth Amendment "lurk in every corner, in every clause."197 It has been suggested that in allowing the president to choose a replacement vice president, the president is doing much more than filling a vacancy in an otherwise elective position. ${ }^{198}$ Instead, when selecting a nominee for vice president, the president does so without the practical input of the electorate. In theory, this then gives a single individual the authority to choose the second highest ranking officer of the United States government. ${ }^{199}$ Even when acknowledging the validity of the preceding objections to the Twenty-fifth Amendment, the more practical and significant outcome is this: on those occasions when there is divided government, the amendment reduces the probability of overturning the mandate of the electorate, as would happen if circumstances dictated, and the Succession Act of 1947 was initiated. 


\section{The Vice Presidency Augmented: By Resources, Institutional Identifiers, and}

\section{Access}

"If you close your left eye and turn your head just right, the great seal of the vice president reads: President of the United States of America." 200

\section{(Vice President Al Gore)}

The history and development of the vice presidency has been infused by perceptions about the institution, perhaps to a greater degree than any other institution in the American system of government. Unquestionably, perceptions about the vice presidency have been informed, in equal parts, by disregard for, and misunderstanding of, the institution. Either way, the perception of an underutilized, and even unwanted, appendage to the government has persisted for much of the history of the institution. It is a view that James Monroe captured well when he pointedly asserted: "The Vice-President is an unnecessary office. I can see no reason for such an office.”201

And yet the vice presidency has developed despite the insolence Monroe evidenced toward the institution, and which many others shared with him. Perhaps this is explained by the inherent authority the vice presidency derives from having been sanctioned in the Constitution. In this vein, the authors of the foremost exposition on political development have posited that "authority works through perceptions. It is strengthened by legitimacy, by the perceptions of all concerned that those formally in control are acting appropriately." 202 In other words, the vice president's place in the scheme of government is reinforced by the legitimacy afforded it by inclusion in the Constitution, which subsequently furthers the perception that the office belongs there. While the Constitution confers authority to the vice president to act as presiding 
officer of the Senate; and similarly the National Security Act of 1947 granted statutory membership for the vice president in the National Security Council; by and large, the vice presidency has developed and thrived by perceptions of what makes the institution whole. Put another way: if, at the Federal Convention of 1787, the office of the vice president was delimited in scope of responsibilities; and to some degree its essentialness to the then nascent American government was not readily apparent; the office has gained a measure of stature and presumed authority from the accumulation of institutional identifiers and tangible resources.

There were no formal identifiers of the office of the vice president for the first 147 years the office existed. Like so much of the development of the vice presidency, it was a president who signaled when and how the institutional vice presidency would expand. While institutional identifiers might seem an insubstantial or even trivial feature of institutions, such identifiers are tangible markers of the institution's permanence. In the case of the American vice presidency, the institutional identifiers attached to the office of the vice president have accumulated incrementally and are a transparent acknowledgment of the institution's development and, of greater consequence, relevance. Apart from gaining a designated office in the Senate wing of the Capitol in 1857, the first tangible identifier of the office of the vice president was the order for a distinct vice-presidential flag. This came about on February 7, 1936 when President Franklin Roosevelt issued Executive Order No. 7285--Prescribing the Official Flag of the Vice President of the United States. Although it was purely a symbolic representation of the vice president's office, Roosevelt's gesture indicated the second office in the land was worthy of the type of accoutrements that were affixed to all other institutions of the 
government.

Later, President Harry Truman issued an executive order for a coat of arms and seal for the office of vice president, as well as a new version of the vice-presidential flag. ${ }^{203}$ Perhaps because he was once vice president, Truman decided to personally oversee the redesign of the flag initially conferred on the office by Franklin Roosevelt. The coat of arms and seal, along with the vice-presidential flag, were then the principal institutional identifiers attached to the office of vice president. Even if such adornments were mainly of aesthetic value, it is a plausible assertion that such visible signs of the office contributed to the further institutionalization of the vice presidency.

The aforementioned Capitol office space for the vice president was a development that President James Buchanan's vice president, John Breckinridge, was the first to benefit from. Breckinridge was destined to serve as a neglected and forgotten vice president, set apart by virtue of being the youngest elected vice president in history. However, prior to Breckinridge's service, the office of vice president was never accorded office space--anywhere. As it happens, what office space the vice president was allowed to use was in the Capitol building and had to be shared with the president. ${ }^{204}$ Hence, when the Capitol was expanded in the 1850s, the Senate membership finally recognized its presiding officer by designating "The Vice President's Room," as a distinct location where the vice president could be found.

The preceding arrangement existed until 1953. Soon after Richard Nixon was elected and inaugurated the thirty-fifth vice president, he was given a cluster of offices in the building housing the Department of State, now named the Harry S. Truman Building. Prompting the expanded office space was a much larger staff for the vice president, at 
least in comparison to earlier vice presidents. Prior to Nixon, vice presidents were allowed minimal staff. For instance, apart from a secretary, it was assumed the vice president was so lacking in tasks that there was no need for support staff, and so none were provided for. And at the turn of the twentieth century, when the vice president was allocated a car and a driver, the incumbent vice president was expected to pay for gas and maintenance.

Harry Truman was the first vice president to have a military aide included among the nominal staff then accorded to the office. Since the United States was thoroughly involved in the Second World War, it made sense to link the vice president, by some means, to the military establishment of the nation. Also, during Truman's brief tenure, for the first time in the history of the second office, the vice president was deemed worthy of the protection of a single Secret Service agent. This was in sharp contrast to four years earlier when then vice president-elect, Henry Wallace, had traveled to Mexico in a caravan of two cars; his entourage included his wife, a driver, two aides, and no security detail.

As for Richard Nixon, after his election to the vice presidency, he was allotted $\$ 47,970$ for an initial staff of nine. Poignantly, this was a considerable drop from when he served as a United States senator and his budget for staff totaled $\$ 70,000 .{ }^{205}$ Nevertheless, the idea that Nixon, as vice president, had need for a staff of nine and a budget was emblematic of the undeniable increase in institutional resources then being made available to the vice president. Twenty-one years later, when Nixon's long time political rival Nelson Rockefeller was appointed to the vice presidency, he was allocated over two million dollars for a staff of more than seventy. 
By 2011, the office of the vice president was included in the federal budget as part of the Executive Office of the President, under the heading: "Special Assistance to the President and the Official Residence of the Vice President." The vice president's salary continues to be paid by the Senate, as are the salaries of vice-presidential assistants assigned primarily to the vice president's offices in the Capitol; otherwise, per the federal budget, allocations for staff salaries, carrying out the various functions of the formal Office of the Vice President, maintenance of the vice president's residence, and " $\$ 90,000$ [to be provided] for official entertainment expenses for the Vice President," totals well over 25 million, per annum. ${ }^{206}$

Perhaps of greater significance than the financial outlays just noted, of the nearly 100 staffers who support Vice President Joe Biden in his work, six of his top assistants, including the chief of staff, are designated an "assistant," "deputy assistant," or "special assistant" to the president--in addition to their formal title within the vice president's office. In a town where perception matters, having high level vice-presidential staffers simultaneously identified with the president and the vice president indicates, in terms of stature, considerable institutional growth for the vice presidency.

Returning to Richard Nixon, in the eight years Nixon was vice president, his staff and Secret Service detail incrementally increased. As was the pattern for the modern vice presidency, every instance of augmentation to the institution paved the way for successive vice presidents to benefit from the expanded institutional resources made available to their predecessors. Therefore, what Nixon had gained, largely via the initiative and support of President Dwight Eisenhower, moved forward to Nixon's successor, Lyndon Johnson. And because the president Johnson served under was 
amenable to continuing what Eisenhower had sanctioned for Nixon, then Johnson started his vice-presidential tenure in a better position than had Nixon.

Yet when Johnson was inaugurated as the number two executive of the nation, he struggled with relinquishing the immense power he possessed as the Senate majority leader. Initially, and to the consternation of many senators, Johnson tried to have it both ways. First, he wanted to lead the Senate Democratic caucus; and then he fought to keep the expansive offices in the Capitol that were reserved for the majority leader. ${ }^{207}$ When both endeavors failed, Johnson had to settle for the presiding officer's chair, and a sprawling suite of offices in what was then known as the Old Executive Office Building. ${ }^{208}$ Indubitably, even being the first vice president to have offices in the historic building--adjacent to the West Wing of the White House--was a minor consolation for a man with Johnson's outsized ego.

Every vice president since Lyndon Johnson has maintained a suite of offices in what is now called the Eisenhower Executive Office Building, as well as the vice president's office in the Senate wing of the Capitol. The move toward expanded office and staff resources that began with Richard Nixon continued and built with each vice president to follow him. When Nixon finally won the presidency in 1968, he seemed to be trending again toward making the vice president a more substantial player in the government. To this end, Nixon gave Spiro Agnew an office in the White House, making him the first vice president in history to have an office there. ${ }^{209}$ Although Nixon's gesture turned out to be purely symbolic, meant only to make the vice president appear integrated within the executive operation, it did allow Agnew, for a time, to get closer to the locus of power than many of his predecessors ever did. 
Although Agnew was forced to relinquish the space, ostensibly to make room for Nixon's staff, the idea of the vice president working from the White House had been made credible. ${ }^{210}$ Therefore, when Jimmy Carter won the presidency, he made sure the vice president was given a private office in the West Wing of the White House--just a few doors down the hall from the Oval Office. It was the earlier arrangement, with the vice president's staff and offices scattered around the capital city, that led Walter Mondale to claim "the vice president... was usually uninformed, uninvited, and often unwanted by the White House." ${ }^{211}$ As it stood, the location and retention of the vice president's office space in the White House was important to Mondale, and for the institution, because the proximity of the vice president to the president indicated access to the power and resources of the presidency, as well. It also meant the vice president was more likely to be included, and therefore influence, deliberations within the president's office, and with the president's staff.

There is probably no better identifier of the American presidency than the White House. Not only does the president work there, the president lives there. The vice presidency, however, not only wanted for distinct office space for the first sixty-eight years the institution was in place, vice presidents were without, in the words of Vice President Calvin Coolidge, "an official residence." ${ }^{212}$ It was Coolidge's view that "the great office should have a settled and permanent habitation and a place, irrespective of the financial ability of its temporary occupant...It would be much more in harmony with our theory of equality if each Vice-President held the same position in the Capital City." ${ }^{213}$

Coolidge's dream for a vice-presidential residence would not be realized in his 
lifetime. Nor was housing for the vice president a concern of just Coolidge; instead, it had been a consideration for every vice president since John Adams first held the office; and, as it would turn out, an official residence would be lacking for thirty-eight of the vice presidents who came to office after Adams. It was not until Gerald Ford was appointed and confirmed to the vice presidency that Congress finally appropriated the funds to acquire a permanent residence for the vice president. ${ }^{214}$ Ford's timely elevation to the presidency, however, did not permit his ever staying in the vice president's house; and so it was the forty-first vice president, Nelson Rockefeller, who had sufficient time to move into the vice president's home on Observatory Hill. Poignantly, Rockefeller possessed ample financial resources; therefore, he could afford to decline public housing. He subsequently opted not to stay in the vice president's residence and used the house solely for social events.

After years of wanting for a permanent residence for the vice president, it would be the third vice president given the opportunity to stay there, Walter Mondale, who finally did. Even though Mondale's vice-presidential record stands on its own, it is still of some meaning that Mondale and his family were the first to live in the official residence provided for the vice president. The house located at the United States Naval Observatory was, in his view, the best house his family had ever inhabited. ${ }^{215}$ Finally, and after only 188 years, the vice president of the United States resided in government housing.

Granting that official flags and seals, and even an official residence, are more symbolic than substantive, there is still value to the vice-presidential institution in possessing such identifiable symbols. As it stands, the perceptible manifestation of institutional resources--such as access to government jets, an extensive staff, and an 
ample office budget--symbolize authority and influence. Whether authority and influence are realized is of course another story, depending entirely on the level of either feature a specific president permits. But of significance, the accumulation of institutional identifiers, in tandem with the increase in tangible resources accorded the vice presidency, have paralleled the expanded policy portfolio that modern vice presidents have incrementally accrued. It is the transformative, accumulative effect of all the preceding institutional markers that have made for the changed vice presidency which stands today. 


\section{Conclusion: The Vice Presidency Today}

"What the Vice President will do or is permitted to do, in the main, is determined by what the President assigns to him or permits him to do and the power and authority that he is willing to share with him. The President can bestow assignments and authority and can

$$
\text { remove that authority and power at will.,"216 }
$$

\section{(Vice President Hubert Humphrey)}

The American vice presidency of the twenty-first century is a decidedly transformed political institution from the one established by the Framers in 1787. As an officer of the national government, meant only to preside in one chamber of the Congress--with no vote except to break a tie among the members of that body, and intended to substitute for the president under certain circumstances, though for a time that was a disputed notion--the vice president is now an officer of the national government, genuinely second only to the president. And yet, "the grotesqueness of the predicament" of the American vice presidency--as Franklin Roosevelt aptly characterized it in 1920-continues to escape the collective consciousness of the nation; it is, again turning to Roosevelt, as if the vice presidency has been accepted as it stands, and taken purely "as a matter of course."217

Contrary to the attitude of indifference assumed by most Americans toward the vice presidency, the vice presidency is a more substantial institution today, than it was when it was first considered at the Federal Convention of 1787. But how could such a transformation have happened? The vice presidency became a government institution by virtue of its establishment in the United States Constitution; yet, the Constitution has not been amended for the purpose of granting additional functions and duties for the vice 
president, beyond those already prescribed. And the two constitutional amendments with a direct bearing on the institution were concerned with ancillary matters, and were not duty related. The first of these, the Twelfth Amendment, was intended to sort out the election process for choosing the president and the vice president. And the second, the Twenty-fifth Amendment, was generated to solidify vice-presidential succession; provide a method for selecting a replacement vice president for those occasions when the second office fell vacant; and managing presidential inability and the procedures for installing the vice president in the capacity of a temporary, acting president.

Other than making the vice president a permanent member of the National Security Council, the institutional framework for the vice presidency has stood as it was created, and perchance just as it was intended. Hence, as an institution of the government, essentially in name only, the vice presidency incrementally and subtly became much more. Twenty-one years into the twentieth century, the inclusion of the vice president in the president's cabinet fostered a more concrete attachment to the executive branch for the vice presidency; it was an attachment previously defined only by the shared election of the top two offices of the national government. However, by mid-century, vice presidents were becoming indispensible deputies to the presidents they served--most notably Henry Wallace and Richard Nixon.

By the 1970s, the growth of the presidency, in tandem with the accumulation of institutional resources available to the president, as well as to the vice president, fostered an expanded reach and presence for the vice president within the executive branch. In conjunction with increased resources came a corresponding level of vice-presidential influence. Even if the nature of such influence was colored by each specific vice 
president and president, a sizable measure of influence was exercised by every vice president, beginning in 1974 with Nelson Rockefeller. The growth of the institution was indisputable by that point and it is a trend that is most likely irreversible. In addition, over time the formal Office of the Vice President began to match, though clearly not in density, the composition of the Executive Office of the President. In light of the preceding, and taken in the aggregate, the American vice presidency had finally arrived; in the process, it had become a fully realized institution of the government.

At the time of this writing, Joe Biden is the vice president of the United States. Based on the example set by his most recent predecessors--Al Gore and Dick Cheney-Biden arrived in office confident that he would be taking on an enhanced political institution. More importantly, he could be certain that Gore and Cheney, by their relations with their respective presidents, had further established the indispensability of the vice president to the president. During the 2008 campaign, Biden framed his then hypothetical vice presidency precisely along these lines, stating:

I would be the point person for the legislative initiatives in the United States Congress for our administration. I would also, when asked if I wanted a portfolio, my response was, no. But Barack Obama indicated to me he wanted me with him to help him govern. So every major decision he'll be making, I'll be sitting in the room to give him my best advice. He's president, not me, I'll give my best advice. ${ }^{218}$

Once inaugurated, Vice President Biden became an unceasing presence by the side of President Barack Obama. And just as Gore and Cheney did before him, Biden was 
equally involved in the post-election and transition activities. This included the placement of key personnel, ensuring he continues to exercise influence on the president, even on those occasions when he is not nearby. Where Biden has transparently differed from Gore and Cheney, however, is in his aversion to the prime ministerial portfolios which helped define the tenures of his predecessors. Although it would be a mischaracterization to claim Biden has escaped entirely the tradition of the vice president leading any number of commissions established by the president, with the most prominent of these being his chairmanship of the Middle Class Task Force. Overall, Biden appears to be involved with President Obama in determining the priorities of the administration, while forging a productive partnership with his president. ${ }^{219}$

It was appropriate that after thirty-six years of service in the United States Senate, Joe Biden was elected vice president and therefore became the president of the Senate. His lengthy service in Congress allowed him to build a network of alliances, Democratic and Republican, which continues to be of considerable value to the Obama administration. And because he possesses a legislative background his president could not begin to approach, of necessity Biden has affected a reemphasis on the vice president in the national legislature. In many respects, this is a return to form and was reflected in the modern era vice presidencies of John Nance Garner, Alben Barkley, Lyndon Johnson, and Hubert Humphrey; all of whom--like Biden--were creatures of the legislative branch. Indeed, Barkley and Humphrey were so at home there that they returned to the Senate after four years of service in the vice presidency.

Yet where Biden differs most from his recent predecessors is the consistency with which he is in the Capitol building. He regularly exercises in the Senate gymnasium and 
when Congress is in session he frequently works in the ceremonial office of the vice president. ${ }^{220}$ Paradoxically, Biden rarely presides, in a sense dodging the principal constitutionally sanctioned function of the position he holds. For the most part, Biden is adhering to what is now a ritual of the vice presidency; tending to the deliberations of the Senate only when it is obvious the vice president's tie breaking vote will be necessary. Still, Biden's activism in and around the Congress extends past presiding and is grounded by his interactions with individual members and, of course, the Democratic caucuses of both chambers.

In the coming years, Vice President Biden's role on Capitol Hill is bound to grow. Moreover, because the vice presidency has developed so much since its inception, over time becoming a highly formidable institution, then by extension the presence of the vice president in Congress is of more significance. Naturally, the extent of Biden's involvement in the legislative branch will be driven in equal parts by fluctuations in the partisan makeup and tenor of the Congress; the cohesiveness of the Democratic Party; and the future political fortunes of both major political parties. But it is the capacity of modern vice presidents to shift their focus from the executive to the legislative realm-and back again, if need be--that makes the hybrid form of the institution so vital. And it is the flexibility of the institution which further compounds the utility of the vice president to the president.

What makes the vice presidency such a fascinating study in institutional development is the ongoing paradox of the office; that being, vice presidents will forever be at the mercy of the president they serve. Apart from where the Constitution addresses the vice president, every other function, identifier, and portfolio affixed to the office of 
vice president exists at the discretion of the incumbent president. It is, in the words of former vice president Dan Quayle, "up to the vice president to do what the president wants."221

Over time the institutional markers identified here have coalesced, making for a fully formed political institution. These institutional markers have reinforced the permanence of the institutional vice presidency; and while the president-to-vice president arrangement is still essential to the efficacy of any vice president's tenure, modern vice presidents find themselves inhabiting an office dissimilar from their eighteenth and nineteenth century predecessors. For those who were or would be vice president in the twentieth and twenty-first centuries are not easily dismissed. In large part this is because the institutional markers that pinpoint the institution's growth have broadly paralleled an increase in public awareness of the office.

But has greater public awareness of the vice presidency resulted in the development of a constituency specific to vice presidents? Along these lines, in the second year of the Clinton presidency, $\mathrm{Al}$ Gore characterized his experience as vice president as one wherein he was routinely exposed to the rigors of the presidency. Gore maintained that since Bill Clinton was "so generous in his definition of our partnership, I have gotten a pretty good taste of what that [the presidency] is really like. And on a daily basis." ${ }^{222}$ Around the same time, Jack Quinn, the vice president's chief of staff, stressed the robustness of the Clinton-Gore association. Quinn anticipated an atypical outcome of the president-to-vice president arrangement Clinton and Gore maintained; predicting that if Gore sought the presidency again, he would "do so with a very real record on which he will be judged, as opposed to" any of his predecessors in the second office. ${ }^{223}$ 
The preceding comments from Gore and his chief of staff raise some questions. If Gore worked in as close proximity to the president as all the evidence indicates, then how would he, as a candidate for president, distinguish himself from Clinton? Or could Gore, if his chief of staff was the more prescient, and if he was unlike previous vice presidents, run for the higher office on a record that stood apart from that of the incumbent president? In other words, is it possible for any vice president to develop a record separate from that of the president, which in turn could facilitate the growth of a constituency specific to the vice president? Using Gore's run for the presidency in 2000 as a benchmark, the argument could be made that, despite eight years of a productive, highly visible vice presidency, Vice President Gore never developed a record, nor a constituency, which was entirely free from a connection to President Clinton and the Clinton administration.

Yet even if the public continues to focus foremost on the presidency, the attachment of the vice presidency, constitutionally and figuratively, to the presidency makes the second office matter. By and large, this is because the vice presidency is insuperably linked to the presidency. This continues despite the transparent augmentation of the vice-presidential institution, and in the face of the, generally, improved caliber of individuals who are willing to run for the job. On the whole, it is an appropriate connection; for were it not for certain presidents, the vice presidency would surely still be identified, as one political scientist described it in the 1950s, as "a hollow shell of an office" occupied by "no one we should like to see" in the presidency. ${ }^{224}$ And yet, while the presidency has made the vice presidency matter, today the modern American vice presidency is no longer entirely in the shadow of the first office of the land. 


\section{Endnotes}

${ }^{1}$ Maclay, Journal, p. 3.

${ }^{2}$ See Appendix C for the text of the Twenty-fifth Amendment to the Constitution of the United States of America.

${ }^{3}$ For an in-depth examination of Calvin Coolidge's life-long battle with depression and how the disease affected Coolidge's life and presidency, see Robert Gilbert's excellent text, The Tormented President: Calvin Coolidge, Death, and Clinical Depression.

${ }^{4}$ Ibid., passim.

${ }^{5}$ See the Twenty-fifth Amendment to the United States Constitution, sec. 3, sec. 4.

${ }^{6}$ Learned, "Some Aspects of the Vice-Presidency," pp. 162-177.

${ }^{7}$ Ibid., p. 172.

${ }^{8}$ Humphrey, "Changes in the Vice Presidency," p. 58.

${ }^{9}$ See Appendix B for the text of the Presidential Succession Act of 1947.

${ }^{10}$ Haig, Inner Circles, p. 353.

${ }^{11}$ For one example of Marie Natoli's brief studies of particular vice presidents see her article "The Vice Presidency: Gerald Ford as Healer." In addition, see Natoli's pair of articles dealing with concerns specific to the viability of the institution: "The Twenty-Fifth Amendment: Opening a Pandora's Box" and "Abolish the Vice Presidency?"

${ }^{12}$ See At the President's Side: The Vice Presidency in the Twentieth Century, edited by Timothy Walch.

${ }^{13}$ Among others, for vice-presidential nominations see William Mayer's useful essay “A Brief History of Vice Presidential Selection,” pp. 313-374. And for public opinion polling and vice presidents, see Jeffrey Cohen's pair of articles: “'The Polls': Popular Views of the Vice President and Vice Presidential Approval,” pp. 142-149; and ““The Polls': Popular Views of the Vice President and Vice Presidential Favorability." Finally, for policy portfolios and vice presidents, specifically the foreign policy portfolio, see the following two articles by Paul Kengor: "The Foreign Policy Role of Vice President Al Gore," pp. 1438; and "The Vice President, Secretary of State, and Foreign Policy," pp. 175-199. 
${ }^{14}$ The book referenced is Jack Lechelt's The Vice Presidency in Foreign Policy: From Mondale to Cheney. It should be noted: only a minimal, cursory examination of the Lechelt text was made by the author, and the conclusions Lechelt makes are not significantly revisited.

${ }^{15}$ Ibid., p. 13.

${ }^{16}$ Mondale, "Sideman," p. 7. The manuscript provided to the author by Walter Mondale of his lecture is capitalized in its entirety; therefore, for all direct quotations from the lecture, capitalization choices have been made at the author's discretion.

${ }^{17}$ Wilson, Constitutional Government, p. 14.

${ }^{18}$ Feerick, From Failing Hands, p. 68.

${ }^{19}$ See Madison, Notes of Debates, p. 368.

${ }^{20}$ Farrand, Framing of the Constitution, p. 160.

${ }^{21}$ Madison, Notes of Debates, p. 368.

${ }^{22}$ Ibid.

${ }^{23}$ Ibid.

${ }^{24}$ Ibid., p. 596.

${ }^{25}$ See John Ferling's Adams vs. Jefferson, passim for a concise retelling of the 1800 presidential election. Also, Bruce Ackerman and David Fontana's article "Thomas Jefferson Counts Himself into the Presidency" gives additional details on the resolution of the 1800 presidential contest.

${ }^{26}$ U.S. Constitution, art. 2, sec. 1.

${ }^{27}$ For a detailed consideration of balancing variables used in making vice-presidential nominations, including region of the country candidates hail from, see Hite, Second Best, Chapter 4, passim.

${ }^{28}$ Hamilton, Federalist (No. 68), p. 444.

${ }^{29}$ On the merits of choosing two candidates for president at the same time, among others see Waugh, Second Consul, p. 26; and Schlesinger's "On the Presidential Succession,” p. 490.

${ }^{30}$ Hamilton, Writings, pp. 149-150.

${ }^{31}$ Ibid., p. 149. 
${ }^{32}$ Ibid.

${ }^{33}$ Schlesinger, Jr., "On the Presidential Succession,” p. 488.

${ }^{34}$ Hamilton, Writings, p. 149.

${ }^{35}$ In Williams, Rise of the Vice Presidency, p. 16.

${ }^{36}$ Hamilton, Federalist, p. 445.

${ }^{37}$ Ibid., pp. 444-445.

${ }^{38}$ Madison, Notes of Debates, p. 596.

${ }^{39}$ Wilson, Congressional Government, p. 162.

${ }^{40}$ Madison, Notes of Debates, p. 596.

${ }^{41}$ Ibid.

${ }^{42}$ Ibid.

${ }^{43}$ Ibid.

${ }^{44}$ Annals of the Congress, $8^{\text {th }}$ Cong., $1^{\text {st }}$ sess., p. 693. James Elliot was a member of the House of Representatives from Vermont.

${ }^{45}$ Hamilton, Federalist, (No. 10) p. 54.

${ }^{46}$ Ibid., p. 57.

${ }^{47}$ Washington, Writings, p. 225.

${ }^{48}$ Although Thomas Jefferson and his adherents--including James Madison and James Monroe--often described themselves as Republicans, they and their associates were also described as Democratic-

Republicans. Since the association of Democratic-Republicans later became the Democratic Party, and was never identified with what became the Republican Party, when describing the former group in this project, only the label of Democratic-Republicans is used.

${ }^{49}$ Thompson, Essay, p. 22. Both the Democratic-Republicans and the Federalists held a caucus of their congressional member in 1796, but there are no official records of either; it is therefore uncertain how formally organized either gathering was. 
${ }^{50}$ Among others, see Thompson's Essay, with regard to the presumptive nominees for president and vice president of the two competing congressional caucuses of 1796, p. 22.

${ }^{51}$ See Smith, "Election of 1796," p. 71; and Ferling, Adams vs. Jefferson, p. 85.

${ }^{52}$ Ibid.

${ }^{53}$ There are countless references to Aaron Burr's alleged designs in the elections of 1796 and 1800. One such example is historian John Ferling, who notes the "suspicions among some" that Aaron Burr was aiming more for the presidency than for the vice presidency; in Adams vs. Jefferson, p. 85.

${ }^{54}$ Smith, "Election of 1796," p. 71.

${ }^{55}$ Page Smith makes the point that Jefferson's followers "had hit upon the strategy of the future by working to create...grass-roots sentiment for their party and their candidate," in "Election of 1796," p. 71.

${ }^{56}$ See Smith, "Election of 1796," p. 71; and Ferling, Adams vs. Jefferson, pp. 87-89.

${ }^{57}$ Ferling, Adams vs. Jefferson, pp. 87-88.

${ }^{58}$ See Smith, "Election of 1796," pp. 70-71; also, Cohen, etc., note the choice of Burr for vice president in 1796 and 1800 specifically because of his connection to New York, which would serve as an effective counter to Thomas Jefferson hailing from Virginia, in Party Decides, p. 63.

${ }^{59}$ Smith, "Election of 1796," p. 71; and Ferling, Adams vs. Jefferson, pp. 87-94.

${ }^{60}$ Smith, "Election of 1796," pp. 71-72.

${ }^{61}$ See Lomask's Aaron Burr, pp. 247-255, for a retelling of the machinations and obstructions preceding Burr's eventual selection. Also, in Adams vs. Jefferson, Ferling points out that the Democratic-Republican caucus, unlike the Federalists caucus, expressly "stipulated a choice for president. Their electors were told that Jefferson was the party's first choice," p. 132.

${ }^{62}$ Lomask, Aaron Burr, pp. 254-255.

${ }^{63}$ Ibid., p. 242.

${ }^{64}$ For a comprehensive description of Burr's role in the New York election see Nathan Schachner's early, definitive text Aaron Burr: A Biography, pp. 167-187. For a similar delineation of Burr's activities in New York that year, see Lomask, Aaron Burr, pp.238-247. 
${ }^{65}$ Lomask comments on how critical it was to obtain New York's twelve electoral votes, in Aaron Burr, p. 237. Also, in Ferling's Adams vs. Jefferson, the author notes John Adams was "stunned" when he discovered that the Democratic-Republicans had captured the state assembly; Adams knew that meant New York's electors were destined to go for the opposition, p. 127.

${ }^{66}$ See Cunningham, “Election of 1800,” pp. 108-109; Lomask, Aaron Burr, pp. 237-240; and Ferling, Adams vs. Jefferson, p. 130.

${ }^{67}$ Lomask, Aaron Burr, p. 240.

${ }^{68}$ Ibid., pp. 240, 244.

${ }^{69}$ For a description of John Adams ostensible campaign travels, see Cunningham, "Election of 1800,” pp. 115-116. Interestingly, in Adams vs. Jefferson, Ferling delineates Adams's itinerary, as well; however he does not characterize Adams's trip as particularly political or successful, p. 139.

${ }^{70}$ Cunningham, "Election of 1800," p. 115; and Ferling, Adams vs. Jefferson, p. 140.

${ }^{71}$ For reference to Burr's campaign activities after the New York contest, see Schachner, Aaron Burr, pp. $183-184$.

${ }^{72}$ The complete text of the letter is reprinted in Hamilton, Writings, "Letter from Alexander Hamilton, Concerning the Public Conduct and Character of John Adams, Esq. President of the United States,” pp. 934-971.

${ }^{73}$ For an assessment of Alexander Hamilton's derogatory letter about John Adams and the probable ramifications of it, see Ferling, Adams vs. Jefferson, pp. 140-143. Also, a review of Aaron Burr's success in obtaining and further circulating Hamilton's letter may be found in Lomask, Aaron Burr, pp. 257-259.

${ }^{74}$ For a useful and interesting take on the Electoral College vote of 1800, see Ackerman and Fontana's "Thomas Jefferson Counts Himself into the Presidency," passim.

${ }^{75}$ According to John Ferling, in Adams vs. Jefferson, there were rumors "of a Federalist conspiracy to assassinate Jefferson," p. 180; as well as indications "Virginia would secede if Jefferson was not elected," p. 188; and for a detailed exposition of the machinations the 1800 election when it went to the House of Representatives for resolution, review pp. 175-196. 
${ }^{76}$ Ferling examines the role played by James Bayard in Adams vs. Jefferson, pp. 189-195.

${ }^{77}$ The idea that Thomas Jefferson struck a deal with Federalists is based on letters written by Aaron Burr and James Bayard, as well from depositions made by Bayard and Samuel Smith; in Ferling, Adams vs. Jefferson, p. 193.

${ }^{78}$ Hofstadter, American Political Tradition, p. 44.

${ }^{79}$ For a retelling of Aaron Burr's role in obtaining and distributing copies of Alexander Hamilton's damning letter about John Adams, see Lomask's Aaron Burr, pp. 257-258.

${ }^{80}$ Hamilton, Writings, p. 514.

${ }^{81}$ One alternative for amending the Constitution stipulates two-thirds of the state legislatures must ask Congress to call a national convention to propose amendments; however, this method has never been utilized. In addition, another method for ratifying a proposed amendment is if ratifying conventions in three-fourths of the states approve the proposed amendment; but so far this method has been utilized for only one amendment.

${ }^{82}$ Annals of the Congress, $8^{\text {th }}$ Cong., $1^{\text {st }}$ sess., p. 673. Also, part of Samuel Dana's speech in the House of Representatives is included in Feerick's From Failing Hands, p. 73.

${ }^{83}$ For a brief summation of the Twelfth Amendment, including the debate in Congress indicating some sentiment for abolishing the vice presidency, see Feerick, From Failing Hands, pp. 72-75.

${ }^{84}$ Madison, Notes of Debates, p. 368.

${ }^{85}$ Annals of the Congress, $8^{\text {th }}$ Cong., $1^{\text {st }}$ sess., p. 693. James Elliot was a member of the House of Representatives.

${ }^{86}$ Quote from Representative Roger Griswold is recorded in Annals of the Congress, $8^{\text {th }}$ Cong., $1^{\text {st }}$ sess., p. 674.

${ }^{87}$ Annals of the Congress, $8^{\text {th }}$ Cong., $1^{\text {st }}$ sess., p. 674.

${ }^{88}$ Ibid.

${ }^{89}$ The text of Alexander Hamilton's "Proposal for the New York Legislature for Amending the Constitution" is included in Hamilton's Writings, p. 982. 
${ }^{90}$ Hamilton, Writings, p. 982.

${ }^{91}$ Ibid.

${ }^{92}$ Appendix A is the text of the Twelfth Amendment to the United States Constitution.

${ }^{93}$ The Twelfth Amendment cementing the pattern of political parties offering a team of candidates for president and vice president is fairly obvious, and has been noted elsewhere; for one early reference to this pattern, see Waugh, Second Consul, p. 50.

${ }^{94}$ Ibid., p. 48.

${ }^{95}$ The tendency for selecting elderly vice presidents is noted by Waugh in Second Consul, pp. 56-58.

${ }^{96}$ Adams, Diary, pp. 520-521.

${ }^{97}$ Tyler was described as "His Accidency" by any number of his contemporaries, and later biographers, though the originator of the unfortunate moniker remains unknown. Among others, Peterson notes the preceding descriptor for Tyler in Presidencies of William Henry Harrison \& John Tyler, p. 50.

${ }^{98}$ Schlesinger, Jr., "On the Presidential Succession,” p. 488.

${ }^{99}$ Madison, Notes of Debates, p. 594.

${ }^{100}$ Ibid., p. 594.

${ }^{101}$ Article II, Section 1, paragraph 6.

${ }^{102}$ Peterson, Presidencies of William Henry Harrison \& John Tyler, p. 45. Peterson also offers a broad consideration of some of the questions to arise about the vice president and presidential succession on pp. $45-50$.

${ }^{103}$ Ibid., p. 48. Also see Dan Monroe's Republican Vision of John Tyler and his claim that Tyler's decision to retain the Harrison cabinet was one he would regret, p. 81

${ }^{104}$ Monroe, Republican Vision of John Tyler, p. 81.

${ }^{105}$ Natoli, “Abolish the Vice Presidency?” p. 203.

${ }^{106}$ U.S. Constitution, Article 2, sec. 1.

${ }^{107}$ Feerick, From Failing Hands, pp. 60-61.

${ }^{108}$ Ibid., pp. 61-62. 
${ }^{109}$ For a broad treatment of the Succession Act of 1886, see Feerick, From Failing Hands, pp. 140-146.

${ }^{110}$ In President Truman's June 19, 1945 message to Congress, Truman argued "the office of the President should be filled by an elective officer," and not individuals nominated by the president.

${ }^{111}$ Feerick, From Failing Hands, p. 205.

${ }^{112}$ Appendix B contains the complete text of the Presidential Succession Act of 1947.

${ }^{113}$ Coolidge, Autobiography, p. 164.

${ }^{114}$ Hatch, History of the Vice-Presidency, p. 378.

${ }^{115}$ President Harding's attorney general, Harry Daugherty, wrote in his memoirs, The Inside Story of the Harding Tragedy, that he came up with the idea of inviting Calvin Coolidge to meetings of the cabinet, pp. $277-278$.

${ }^{116}$ Interview with Francis J. Attig, United States Senate Historical Office--Oral History Project, April 5, 1978, p. 73. Interview conducted by Donald A. Ritchie.

${ }^{117}$ Ibid.

${ }^{118}$ For the paragraph Woodrow Wilson devoted to the vice presidency, see Congressional Government, $\mathrm{p}$. 162.

${ }^{119}$ Ibid.

${ }^{120}$ Testimony of Clark Clifford, U.S. Congress, Senate, $84^{\text {th }}$ Cong., $2^{\text {nd }}$ sess., January 16,24 , and $25,1956$. Subcommittee on Reorganization of the Committee on Government Operations: Proposal to Create Position of Administrative Vice President, p. 56.

${ }^{121}$ In the biography, Calvin Coolidge: The Man From Vermont, Claude Fuess asserts that "Harding had great confidence in Coolidge, consulted him frequently, and was influenced by him to a marked degree," but when it came to the cabinet Fuess claims Coolidge "seldom participated in the cabinet discussions," p. 288 and p. 289.

${ }^{122}$ Daugherty, Inside Story of the Harding Tragedy, p. 278. 
${ }^{123}$ The one exception to the vice president sitting with the cabinet was Charles Dawes, vice president to Calvin Coolidge. Dawes gave his opinion of why the vice president should not attend meetings of the cabinet in his Notes as Vice President, pp. 33-34.

${ }^{124}$ The demarcation of the modern American vice presidency commencing with Vice President Coolidge's inclusion in the cabinet was first made by the author in the fifth chapter of Second Best.

${ }^{125}$ Coolidge, Autobiography, pp. 163-164.

${ }^{126}$ Dawes, Notes as Vice President, p. 33.

${ }^{127}$ In a curious oversight, political scientist Joel Goldstein claims John Garner was the first vice president to regularly attend cabinet meetings; then later, in the same text, he identifies Calvin Coolidge as the first vice president to meet with the cabinet, only to follow that by incorrectly asserting, on the same page, that Herbert Hoover never invited Charles Curtis to attend cabinet meetings; in Modern American, p. 8 and p. 136.

${ }^{128}$ Orren, Search for American Political Development, p. 129.

${ }^{129}$ Roosevelt, "Can the Vice President be Useful?" p. 81.

${ }^{130}$ For a comprehensive evaluation of several of the more substantial president-to-vice president relationships that have historically gone unrecognized, see Hite, Second Best, specifically Chapter 3, passim.

${ }^{131}$ Marshall, Recollections, pp. 16-17.

${ }^{132}$ For Franklin Roosevelt's early thoughts on the American vice presidency, see his article from 1920, "Can the Vice President be Useful?"

${ }^{133}$ Franklin Roosevelt offers a succinct delineation of how and why the vice president could be used as a liaison between the executive and legislative branches in "Can the Vice President be Useful?", p. 8. And for a detailed review of the Roosevelt-Garner association, including the specific differences which led to their parting of ways, see Hite, Second Best, Chapter 5, subsection: "Back In the Cabinet (1929-1941)."

${ }^{134}$ For a thorough review of Franklin Roosevelt and the choice of Henry Wallace for his running mate in 1940, see Schapsmeier, Henry A. Wallace of Iowa, pp. 265-273. 
${ }^{135}$ Wallace, "How a Vice President is Picked--Inside Look at U.S. Politics,” p. 88.

${ }^{136}$ Schapsmeier, Henry A. Wallace of Iowa, p. 269.

${ }^{137}$ For a useful review of the Wallace-Jones conflict, see the chapter devoted exclusively to it in Schapsmeier, Prophet in Politics, pp. 50-71.

${ }^{138}$ Humphrey, "Changes in the Vice Presidency," p. 59.

${ }^{139}$ Ibid. Though not in reference to Henry Wallace specifically, Hubert Humphrey makes the same point about the vice president "outranking" other members of the cabinet.

${ }^{140}$ Wallace, Price of Vision, p. 452.

${ }^{141}$ Barkley, That Reminds Me, p. 207.

${ }^{142}$ Ambrose discusses President Eisenhower's assignment of administrative tasks to Vice President Nixon, in Nixon, p. 30.

${ }^{143}$ Transcript, James E. Webb Oral History Interview I, April 29, 1969, by T.H. Baker, Internet Copy, LBJ Library, p. 7.

${ }^{144}$ Humphrey, Education of a Public Man, p. 407.

${ }^{145}$ Ibid., p. 356.

${ }^{146}$ For a detailed exposition on the Agnew vice presidency, including Richard Nixon's motives for choosing Spiro Agnew for his vice-presidential running mate, see Hite, Second Best, Chapter 6, subsection: “The Vice Presidency Served: By Resignation and Presidential Selection (1969-1977).”

${ }^{147}$ Humphrey, Education of a Public Man, p. 437.

${ }^{148}$ Ford notes his preparation for the presidency, while still vice president, in Time to Heal, p. 121; as does Cannon, in "Gerald R. Ford and Nelson A. Rockefeller," p. 136.

${ }^{149}$ Ford, Time to Heal, p. 142.

${ }^{150}$ Ibid.

${ }^{151}$ According to James Cannon's account: when it became apparent Vice President Agnew would have to resign, Nelson Rockefeller considered actively campaigning for the spot, on the assumption the vice 
presidency was his best chance to finally gain the presidency; in "Gerald R. Ford and Nelson A.

Rockefeller," pp. 137-138.

${ }^{152}$ Gerald Ford briefly summarizes the responsibilities he discussed with Rockefeller when the latter man agreed to have his name put forward for vice president; in Time to Heal, p. 145. For an extensive review of what Rockefeller expected versus what he got once he was confirmed as vice president, see Turner, “Finding a Policy Role,” passim, and specifically, pp. 262-271. In addition, Light refers to Rockefeller's expectations for a role in domestic policy, as conveyed to him by Ford, in Vice-Presidential Power, p. 179.

${ }^{153}$ In Cannon, “Gerald R. Ford and Nelson A. Rockefeller,” p. 139; and Light, Vice-Presidential Power, p. 179.

${ }^{154}$ For a detailed summation of the obstructionism Vice President Nelson Rockefeller experienced when he was leading the Domestic Council, see Hite, Second Best, Chapter 6, subsection: "The Vice Presidency Served: By Resignation and Presidential Selection (1969-1977).” In addition, there is copious anecdotal evidence of Rockefeller's troubles President Ford's aides, including from Henry Kissinger who asserted: “the White House staff systematically undercut Rockefeller's role as vice chairman of the Domestic Council, to which Ford had appointed him," in Years of Renewal, p. 188.

${ }^{155}$ The practice of weekly private meetings between the president and vice president is typically credited to President Jimmy Carter and Vice President Walter Mondale; however, it was actually Ford and Rockefeller who began the ritual of weekly meetings. Among others, see Ford on his meetings with the vice president, in Time to Heal, p. 327.

${ }^{156}$ For a concise, though skeptical review of the various investigations into the Central Intelligence Agency during the 1970s, see Kissinger, Years of Renewal, pp. 310-343.

${ }^{157}$ Ibid., p. 188.

${ }^{158}$ For some brief points about Senator Bob Dole's vice-presidential candidacy in 1976, see Hite, Second Best, Chapter 4; and in the same text, see Chapter 6 for a detailed account of Vice President Nelson Rockefeller not being retained for the ticket with President Ford.

${ }^{159}$ Ford, Time to Heal, p. 328; and Kissinger, Years of Renewal, p. 837. 
${ }^{160}$ See Mondale, "The Role of the Vice President in the Carter Administration," December 9, 1976. A copy of Vice President-elect Walter Mondale's memo to President-elect Jimmy Carter is available at the website of the Minnesota Historical Society, Walter F. Mondale Collection.

${ }^{161}$ Mondale, "Sideman," pp. 6-7.

162 Ibid., p. 7.

${ }^{163}$ Carter, Keeping Faith, p. 39.

${ }^{164}$ Ibid.

${ }^{165}$ Mondale, "Sideman,”p. 8.

${ }^{166}$ For a cursory account of Senator Dan Quayle on the campaign trail, and the impact his performance there had on his political future, see Hite, Second Best, Chapter 4, subsection: "Vice-Presidential Nominees and Debates," and Chapter 6, subsection: "The Vice Presidency Served: A Caricature Restored (19891993)."

${ }^{167}$ Quayle, phone interview with the author, March 4, 2009.

${ }^{168}$ Broder, Man Who Would Be President, p. 130.

${ }^{169}$ Quayle, phone interview with the author, March 4, 2009.

${ }^{170}$ Mark Gearan quoted in Ann Devroy and Stephen Barr's, “Gore Bucks Tradition in Vice President's Role," The Washington Post, February 18, 1995. In addition, George Stephanopoulos is quoted as saying nearly the same as does Gearan, in Elaine Sciolino and Todd S. Purdum's article, "Al Gore, One Vice President Who is Eluding the Shadows.” The New York Times, February 19, 1995.

${ }^{171} \mathrm{Al}$ Gore is quoted in Elaine Sciolino and Todd S. Purdum's article: “Al Gore, One Vice President Who is Eluding the Shadows." The New York Times, February 19, 1995.

${ }^{172}$ Christopher, Chances of a Lifetime, pp. 155-156.

${ }^{173}$ There are numerous evaluations of the National Performance Review; for just two, see J.R. Thompson's article "Reinvention as Reform: Assessing the National Performance Review," Public Administration Review, Vol. 60, no. 6, (November-December, 2000), pp. 508-520; and L. Lenkowky and J.L. Perry's article "Reinventing Government: the Case for National Service," Public Administration Review, Vol. 60, 
no. 4, (July-August, 2000), pp. 298-307. And for Al Gore's personal assessment of specific outcomes of the National Performance Review, as applied to the executive in the federal bureaucracy, see his article "The New Job of the Federal Executive,” Public Administration Review, Vol. 54, no. 4, (July-August, 1994), pp. 317-321.

${ }^{174}$ Clinton, My Life, p. 647.

${ }^{175}$ Ibid., p. 648.

${ }^{176}$ Based on data verified by the Senate Historical Office; included in the document: "Occasions When Vice Presidents Have Voted to Break Tie Votes in the Senate," March 13, 2008.

${ }^{177}$ Ibid.

${ }^{178}$ Ibid.

${ }^{179}$ President Clinton is quoted in Richard L. Berke's “The Good Son,” The New York Times, February 20, 1994.

${ }^{180}$ President Johnson's remarks are recounted in Humphrey, Education of a Public Man, p. 301.

${ }^{181}$ Although it is uncertain if the original suggestion that Bush and Cheney shared a "co-presidency" originated with Shirley Warshaw, for a book-length treatment of the idea, see her text The Co-Presidency of Bush and Cheney, passim.

${ }^{182}$ For a consideration of collegial executives see Shugart, Presidents and Assemblies, pp. 20-11, 95-105, 219,285

${ }^{183}$ In a presidential system the veto is broadly recognized for being "the primary check of the president on congressional power," in Shugart, Presidents and Assemblies, p. 134.

${ }^{184}$ For a consideration of Dick Cheney as vice president, see Hite, Second Best, Chapter 8, "The Vice Presidency Unbounded: The Case of Cheney." And for Cheney and the transition, specifically, see Chapter 8, subsection: "Dick Cheney and the Assimilation of the Vice Presidency into the Presidency."

${ }^{185}$ Transcript, Lieberman-Cheney Vice-Presidential Debate, October 5, 2000, p. 11.

${ }^{186}$ Presidential memorandum, George W. Bush, January 29, 2001. 
${ }^{187}$ For the composition of the National Energy Policy Development Group, see the hierarchical representation of the group in the United States General Accounting Office report, "Energy Task Force," GAO-03-894, p. 7.

${ }^{188}$ Among the better accounts of the consistent disengagement of President George W. Bush during his first years in office is Ron Suskind's entertaining book, The Price of Loyalty: George W. Bush, the White House, and the Education of Paul O'Neill.

${ }^{189}$ Among the accounts of the anonymity of participants in the Cheney energy force meetings, as well as efforts to discover who was actually at the meetings, The New York Times article of April 25, 2004, “Administration Says a 'Zone of Autonomy’ Justifies Its Secrecy on Energy Task Force,” by Linda Greenhouse, is one of the more concise. Also, for a more scholarly treatment of the same topic, see Halstead's “"The Law: Walker v. Cheney”: Legal Insulation of the Vice President from GAO Investigations," pp. 635-648. And for the Bush administration's assertion of executive privilege for the vice president, see Cheney v. United States District Court, No. 03-475.

${ }^{190}$ For Dick Cheney's view on executive power and the presidency, see his article: "The Significance of Campaign '84," passim.

${ }^{191}$ Timmons, Garner of Texas, p. 205.

${ }^{192}$ In his book, One Heartbeat Away: Presidential Disability and Succession, Senator Birch Bayh documents the arduous task of initiating, drafting, and passing the Twenty-fifth Amendment to the Constitution, passim.

${ }^{193}$ For the entire text of the Twenty-fifth Amendment to the United States Constitution, see Appendix C.

${ }^{194}$ For the text of the Presidential Succession Act of 1947, see Appendix B.

${ }^{195}$ Schlesinger, “On the Presidential Succession,” p. 500.

${ }^{196}$ Ibid.

${ }^{197}$ Natoli, “The Twenty-Fifth Amendment: Opening a Pandora's Box,” p. 50.

${ }^{198}$ In addition to Schlesinger's criticism of the part the president plays in choosing a replacement vice president, in "On the Presidential Succession," see Natoli's "The Twenty-Fifth Amendment: Opening a 
Pandora's Box," for her broad concerns with the amendment, in particular that part of the amendment which deals with presidential inability.

${ }^{199}$ Schlesinger, "On the Presidential Succession,” p. 500.

${ }^{200}$ Al Gore made the joke first when he appeared on "The Late Show with David Letterman," which aired on September 6, 1993. Gore later used a slightly altered version of the same joke in an address before the Armed Forces Communications and Electronics Association Conference on February 13, 1996.

${ }^{201}$ James Monroe is quoted, without attribution, in Barkley, "The Vice-Presidency,” p. 4.

202 Orren, Search for American Political Development, p. 125.

${ }^{203}$ Executive Order No. 10016--Coat of Arms, Seal, and Flag of the Vice President of the United States, November 10, 1948, President Harry S. Truman. Truman's executive order revoked Executive Order No. 7285--Prescribing the Official Flag of the Vice President of the United States, February 7, 1936, President Franklin D. Roosevelt.

${ }^{204}$ According to the pamphlet, "The Vice President's Room," produced by the Office of Senate Curator: "Due to lack of space in the Capitol's old Senate wing, early vice presidents often shared their room with the president. Following the 1850s extension of the building, the Senate formally set aside a room for the vice president's exclusive use."

${ }^{205}$ Ambrose, Nixon, p. 303.

${ }^{206}$ Data on the budget allocations for the Office of the Vice President are derived from the Federal Government Manual, "Special Assistance to the President and the Official Residence of the Vice President," p. 1147.

${ }^{207}$ Interview with George A. Smathers, "Interview \#4: Kennedy and Johnson," United States Senate Historical Office--Oral History Project, September 5, 1989, pp. 88-89. Interview conducted by Donald A. Ritchie. In addition, for Lyndon Johnson's attempt to lead the Senate Democratic caucus as vice president, see Transcript, Hubert H. Humphrey Oral History Interview I, August 17, 1971, by Joe B. Frantz, Internet Copy, LBJ Library, p. 21. 
${ }^{208}$ Katherine Scott, United States Senate Historical Office, personal communication with the author, June 11, 2010. What was commonly referred to as the Old Executive Office Building (OEOB) was renamed the Eisenhower Executive Office Building.

${ }^{209}$ Agnew, Go Quietly, p. 36.

${ }^{210}$ Ibid.

${ }^{211}$ Mondale, "Sideman," p. 7.

${ }^{212}$ Coolidge, Autobiography, p. 159.

${ }^{213}$ Ibid., pp. 159-160.

${ }^{214}$ Gail S. Cleere's text, The House on Observatory Hill: Home of the Vice President of the United States, offers an informative history of "Admirals House," located at the Naval Observatory in Washington, DC.

${ }^{215}$ Mondale is quoted without attribution in Lewis, Mondale, p. 231.

${ }^{216}$ Humphrey, "Changes in the Vice Presidency," p. 59.

${ }^{217}$ Both quotes are from Roosevelt, "Can the Vice President be Useful?" p. 8.

${ }^{218}$ Transcript, Biden-Palin Vice-Presidential Debate, October 2, 2008, p. 34.

${ }^{219}$ For an assessment of Vice President Joe Biden and his role in the Obama administration, see the October 19, 2009 edition of Newsweek, with Holly Bailey and Evan Thomas's accompanying article about Biden, “An Inconvenient Truth Teller."

${ }^{220}$ See Helene Cooper's article, "As the Ground Shifts, Biden Plays a Bigger Role,” The New York Times, December 11, 2010.

${ }^{221}$ Quayle, phone interview with the author, March 4, 2009.

${ }^{222}$ Richard L. Berke, “The Good Son,” The New York Times, February 20, 1994.

${ }^{223}$ Ibid.

${ }^{224}$ Rossiter, American Presidency, p. 100. 


\section{Bibliography}

Ackerman, Bruce and David Fontana. "Thomas Jefferson Counts Himself into the Presidency.” Virginia Law Review, Vol. 90, no. 2, (April, 2004), pp. 551-643.

Adams, John Q. The Diary of John Quincy Adams, 1794-1845, edited by Allan Nevins. New York: Fredrick Ungar Publishing Co., 1969. First published in 1951 by Fredrick Ungar Publishing Co. Page references are to the 1969 edition.

Agnew, Spiro T. Go Quietly...or Else. New York: William Morrow and Company, Inc., 1980.

Ambrose, Stephen E. Nixon: The Education of a Politician, 1913-1962. New York: Simon and Schuster, 1987.

Barkley, Alben W. "The Vice-Presidency." May, 1952, unpublished. Box 164, Alben W. Barkley Collection, University of Kentucky, Special Collections Library.

Barkley, Alben W. That Reminds Me. New York: Doubleday \& Company, Inc., 1954. A facsimile of the first edition. Ann Arbor, MI: University Microfilms, 1970.

Bayh, Birch. One Heartbeat Away: Presidential Disability and Succession. New York: The Bobbs-Merrill Company, Inc., 1968.

Broder, David S. and Bob Woodward. The Man Who Would Be President: Dan Quayle. New York: Simon \& Schuster, 1992.

Cannon, James. “Gerald R. Ford and Nelson A. Rockefeller: A Vice-Presidential Memoir." In At the President's Side: The Vice Presidency in the Twentieth Century, edited by Timothy Walch, pp. 135-143. Columbia: University of Missouri Press, 1997. 
Carter, Jimmy. Keeping Faith: Memoirs of a President. New York: Bantam Books, 1982.

Cheney, Richard B. “The Significance of Campaign '84." Presidential Studies Quarterly, Vol. 14, no. 3, Campaign '84: The Contest for National Leadership (Part Three) (Summer, 1984), pp. 335-340.

Christopher, Warren. Chances of a Lifetime. New York: Scribner, 2001.

Cleere, Gail S. The House on Observatory Hill: Home of the Vice President of the United States. Washington, DC: U.S. Government Printing Office, 1989.

Clinton, Bill. My Life. New York: Alfred A. Knopf, 2004.

Cohen, Jeffrey E. ““The Polls': Popular Views of the Vice President and Vice Presidential Approval.” Presidential Studies Quarterly, Vol. 31, no. 1, (March, 2001), pp. 142-149.

Cohen, Jeffrey E. ““The Polls': Popular Views of the Vice President and Vice Presidential Favorability." Presidential Studies Quarterly, Vol. 31, no. 2, (June, 2001), pp. 349-357.

Cohen, Marty, David Karol, Hans Noel, and John Zaller. The Party Decides: Presidential Nominations Before and After Reform. Chicago: The University of Chicago Press, 2008.

Coolidge, Calvin J. The Autobiography of Calvin Coolidge. New York: Cosmopolitan Book Corporation, 1929.

Cunningham, Noble E., Jr. "Election of 1800.” In History of American Presidential Elections, 1789-1968, edited by Arthur M. Schlesinger, Jr., Fred L. Israel, and 
William P. Hansen, Vol. 1, pp. 101-134. New York: Chelsea House Publishers, 1971.

Daugherty, Harry M. The Inside Story of the Harding Tragedy. New York: The Churchill Company, 1932.

Dawes, Charles G. Notes as Vice President 1922-1929. Boston: Little, Brown, and Company, 1935.

Farrand, Max. The Framing of the Constitution of the United States. New Haven, CT: Yale University Press, 1913.

Feerick, John D. From Failing Hands: The Story of Presidential Succession. New York: Fordham University Press, 1965.

Ferling, John. Adams vs. Jefferson: The Tumultuous Election of 1800. New York: Oxford University Press, 2004.

Ford, Gerald R. A Time to Heal: The Autobiography of Gerald R. Ford. New York: Harper \& Row Publishers, 1979.

Timmons, Bascom N. Garner of Texas: A Personal History. New York: Harper \& Brothers Publishers, 1948.

Gilbert, Robert E. The Tormented President: Calvin Coolidge, Death, and Clinical Depression. Westport, CT: Praeger Publishers, 2003.

Haig, Alexander M. Jr. Inner Circles: How America Changed the World, A Memoir. New York: Warner Books, Inc., 1992.

Hamilton, Alexander. Writings. New York: The Library of America, 2001. 
Hamilton, Alexander, John Jay, and James Madison. The Federalist: A Commentary on the Constitution of the United States. New York: The Modern Library, 1941.

Hite, James E. Second Best: The History and Development of the American Vice Presidency, forthcoming.

Hofstadter, Richard. The American Political Tradition: And the Men Who Made It. New York: Vintage Books, 1989. First published 1948 by Alfred Knopf, Inc. Page references are to the 1989 edition.

Humphrey, Hubert H. "Changes in the Vice Presidency." Current History, 67 (August 1974), pp. 58-59, 89-90.

Humphrey, Hubert H. The Education of a Public Man: My Life and Politics, edited by Norman Sherman. New York: Doubleday \& Company, Inc., 1976.

Kengor, Paul. “The Foreign Policy Role of Vice President Al Gore.” Presidential Studies Quarterly, Vol. 27, no. 1, Bill Clinton and Al Gore: Retrospect and Prospect (Winter, 1997), pp. 14-38.

Kengor, Paul. "The Vice President, Secretary of State, and Foreign Policy.” Political Science Quarterly, Vol. 115, no. 2, (Summer, 2000), pp. 175-199.

Kissinger, Henry. Years of Renewal. New York: Simon \& Schuster, 1999.

Learned, H.B. "Some Aspects of the Vice-Presidency." Proceedings of the American Political Science Association, Vol. 9, Ninth Annual Meeting, (1912), pp. 162-177. Lechelt, Jack. The Vice Presidency in Foreign Policy: From Mondale to Cheney. El Paso: TX: LFB Scholarly Publishing LLC, 2009. 
Lewis, Finlay. Mondale: Portrait of an American Politician. New York: Perennial Library, 1984. First published 1980 by Harper \& Row Publishers, Inc., hardcover edition. Page references are to the 1984 edition.

Light, Paul C. Vice-Presidential Power: Advice and Influence in the White House. Baltimore, MD: The Johns Hopkins University Press, 1984.

Lomask, Milton. Aaron Burr: The Years From Princeton to Vice President, 1756-1805. New York: Farrar, Straus, Giroux, 1979.

Maclay, William and Edgar Stanton Maclay. Journal of William Maclay: United States Senator from Pennsylvania, 1789-1791. New York: D.A. Appleton and Co., 1890. Madison, James. Notes of Debates in the Federal Convention of 1787. New York: W.W. Norton \& Company, Inc., 1966.

Marshall, Thomas R. Recollections of Thomas R. Marshall: A Hoosier Salad. Indianapolis: The Bobbs-Merrill Company, 1925.

Mayer, William G. "A Brief History of Vice Presidential Selection.” In Pursuit of the White House 2000: How We Choose Our Presidential Nominees, edited by William G. Mayer, pp. 313-374. New York: Chatham House Publishers, 2000.

Mondale, Walter F. "Sideman: Reflections on the Vice Presidency.” Lecture at Macalester College, St. Paul, Minnesota, May 6, 2002. Page references are to the manuscript copy provided to the author by Walter F. Mondale.

Monroe, Dan. The Republican Vision of John Tyler. College Station: Texas A \& M University Press, 2003. 
Natoli, Marie D. “The Twenty-Fifth Amendment: Opening a Pandora's Box.” Presidential Studies Quarterly, Vol. 6, no. 4, (Fall, 1976), pp. 48-50.

Natoli, Marie D. “Abolish the Vice Presidency?” Presidential Studies Quarterly, Vol. 9, no. 2, Leadership and Reform (Spring, 1979), pp. 202-206.

Natoli, Marie D. “The Vice Presidency: Gerald Ford as Healer.” Presidential Studies Quarterly, Vol. 10, no. 4, (Fall, 1980), pp. 662-664.

Natoli, Marie D. “The Humphrey Vice Presidency in Retrospect.” Presidential Studies Quarterly, Vol. 12, no. 4, Perceptions on the Presidency, Leadership, and Statesmanship, (Fall, 1982), pp. 603-609.

Orren, Karen and Stephen Skowronek. The Search for American Political Development. Cambridge, UK: Cambridge University Press, 2004.

Peterson, Norma Lois. The Presidencies of William Henry Harrison \& John Tyler. Lawrence: University Press of Kansas, 1989.

Quayle, Dan. Phone interview with the author, March 4, 2009.

Roosevelt, Franklin D. “Can the Vice President be Useful?” The Saturday Evening Post, October 16, 1920, pp. 8, 81-82.

Rossiter, Clinton L. “The Reform of the Vice Presidency," Political Science Quarterly, Vol. 63, no. 3, (September, 1948), pp. 383-404.

Schachner, Nathan. Aaron Burr: A Biography. New York: Frederick A. Stokes Company, 1937.

Schapsmeier, Edward L. and Fredrick H. Schapsmeier. Henry A. Wallace of Iowa: The Agrarian Years, 1910-1940. Ames: The Iowa State University Press, 1968. 
Schapsmeier, Edward L. and Fredrick H. Schapsmeier. Prophet in Politics: Henry A.

Wallace and the War Years, 1940-1965. Ames: The Iowa State University Press, 1970.

Schlesinger, Arthur M. Jr. “On the Presidential Succession.” Political Science Quarterly, 89, no. 3, (Autumn 1974), pp. 475-505.

Smith, Page. "Election of 1796." In History of American Presidential Elections, 17891968, edited by Arthur M. Schlesinger, Jr., Fred L. Israel, and William P. Hansen,Vol. 1, pp. 59-80. New York: Chelsea House Publishers, 1971.

Suskind, Ron. The Price of Loyalty: George W. Bush, the White House, and the Education of Paul O'Neill. New York: Simon \& Schuster, 2004.

Thompson, Charles S. An Essay On: The Rise and Fall of the Congressional Caucus as a Machine for Nominating. New Jersey: Yale University, 1902. A facsimile of the first edition. Ann Arbor, MI: University Microfilms, 1971.

Turner, Michael. "Finding a Policy Role for the Vice President: The Case of Nelson A. Rockefeller." PhD diss., State University of New York, 1978.

U.S. Congress. Annals of the Congress of the United States, 1789-1824. 42 vols. Washington, DC, 1834-56.

Wallace, Henry A. "How a Vice President is Picked--Inside Look at U.S. Politics." U.S. News \& World Report, April 6, 1956, pp. 86-89. Full text of an address delivered to the Harvard Law School Forum, March 30, 1956.

Wallace, Henry A. The Price of Vision: The Diary of Henry A. Wallace, 1942-1946, edited by John Morton Blum. Boston, MA: Houghton Mifflin Company, 1973. 
Warshaw, Shirley A. The Co-Presidency of Bush and Cheney. Stanford, CA: Stanford University Press, 2009.

Washington, George. The Writings of George Washington: From the Original Manuscript Sources, 1745-1799, edited by John C. Fitzpatrick. Vol. 35, March 30, 1796-July 31, 1797. Westport, CT: Greenwood Press, Publishers, 1970. First published 1940 by the United States Government Printing Office. Page references are to the 1970 edition.

Waugh, Edgar W. Second Consul: The Vice Presidency: Our Greatest Political Problem. New York: The Bobbs-Merrill Company, Inc., 1956.

Williams, Irving G. The Rise of the Vice Presidency. Washington, DC: Public Affairs Press, 1956.

Wilson, Woodrow. Congressional Government: A Study in American Politics. New York: Riverside Press, Houghton Mifflin Company, 1885. Reprinted with introduction by Walter Lippmann. New York: Meridian Books, 1956. Reprinted 2006 by Dover Publications, paperback edition. Page references are to the 2006 edition.

Wilson, Woodrow. Constitutional Government in the United States. New York: The Columbia University Press, 1908. 


\section{Appendix A}

\section{The Twelfth Amendment to the Constitution of the United States of America}

Proposed by resolution of the Congress on December 9, 1803; declared ratified by three fourths of the States on September 25, 1804.

Article [XII]

The Electors shall meet in their respective states, and vote by ballot for President and Vice-President, one of whom, at least, shall not be an inhabitant of the same state with themselves; they shall name in their ballots the person voted for as President, and in distinct ballots the person voted for as Vice-President, and they shall make distinct lists of all persons voted for as President, and of all persons voted for as Vice-President, and of the number of votes for each, which lists they shall sign and certify, and transmit sealed to the seat of the government of the United States, directed to the President of the Senate;--The President of the Senate shall, in the presence of Senate and House of Representatives, open all the certificates and the votes shall then be counted;--The person having the greatest number of votes for President, shall be the President, if such number be a majority of the whole number of Electors appointed; and if no person have such majority, then from the persons having the highest numbers not exceeding three on the list of those voted for as President, the House of Representatives shall choose immediately, by ballot, the President. But in choosing the President, the votes shall be taken by states, the representation from each state having one vote; a quorum for this purpose shall consist of a member or members from two-thirds of the states, and a majority of all the states shall be necessary to a choice. [And if the House of 
Representatives shall not choose a President whenever the right of choice shall devolve upon them, before the fourth day of March next following, then the Vice-President shall act as President, as in the case of the death or other constitutional disability of the President.] The person having the greatest number of votes as Vice-President, shall be the Vice-President, if such a number be a majority of the whole number of Electors appointed, and if no person have a majority, then from the two highest numbers on the list, the Senate shall choose the Vice-President; a quorum for the purpose shall consist of two-thirds of the whole number of Senators, and a majority of the whole number shall be necessary to a choice. But no person constitutionally ineligible to the office of President shall be eligible to that of Vice-President of the United States. 


\section{Appendix B}

\section{The Presidential Succession Act of 1947}

An act to provide for the performance of the duties of the office of President in case of the removal, resignation, death, or inability both of the President and Vice President.

July 18,1947

\section{U.S. Stat. 380}

"Be it enacted, etc., That (a) (1) if, by reason of death, resignation, removal from office, inability, or failure to qualify, there is neither a President nor Vice President to discharge the powers and duties of the office of President, then the Speaker of the House of Representatives shall, upon his resignation as Speaker and as Representative in Congress, act as President.

"(2) The same rule shall apply in case of the death, resignation, removal from office, or inability of an individual acting as President under this subsection.

"(b) If, at the time when under subsection (a) a Speaker is to begin the discharge of the powers and duties of the office of President, there is no Speaker, or the Speaker fails to qualify as Acting President, then the President pro tempore of the Senate shall, upon his resignation as President pro tempore and as Senator, act as President.

“(c) An individual acting as President under subsection (a) or subsection (b) shall continue to act until the expiration of the then current Presidential term, except that--

(1) if his discharge of the powers and duties of the office is founded in whole or in part on the failure of both the President-elect and the Vice President-elect to qualify, then he shall act only until a President or Vice President qualifies; and 
(2) if his discharge of the powers and duties of the office is founded in whole or in part on the inability of the President or Vice President, then he shall act only until the removal of the disability of one such individuals.

“(d) (1) If, by reason of death, resignation, removal from office, inability, or failure to qualify, there is no President pro tempore to act as President under subsection (b), then the officer of the United States who is highest on the following list, and who is not under disability to discharge the powers and duties of the office of President shall act as President: Secretary of State, Secretary of the Treasury, Secretary of War, Attorney General, Postmaster General, Secretary of the Navy, Secretary of the Interior, Secretary of Agriculture, Secretary of Commerce, Secretary of Labor.

“(2) An individual acting as President under this subsection shall continue so to do until the expiration of the then current Presidential term, but not after a qualified and prior-entitled individual is able to act, except that the removal of the disability of an individual higher on the list contained in paragraph (1) or the ability to qualify on the part of an individual higher on such list shall not terminate his service.

“(3) The taking of the oath of office by an individual specified in the list in paragraph (1) shall be held to constitute his resignation from the office by virtue of the holding of which he qualifies to act as President.

“(e) Subsections (a), (b), and (d) shall apply only to such officers as are eligible to the office of President under the Constitution. Subsection (d) shall apply only to officers appointed, by and with the advice and consent of the Senate, prior to the time of the death, resignation, removal from office, inability, or failure to qualify, of the President 
pro tempore, and only to officers not under impeachment by the House of

Representatives at the time the powers and duties of the office of President devolve upon them.

"(f) During the period that any individual acts as President under this Act, his compensation shall be at the rate then provided by law in the case of the President.

“(g) Sections 1 and 2 of the Act entitled 'An Act to provide for the performance of the duties of the office of President in case of the removal, death, resignation, or inability both of the President and Vice President', approved January 19, 1886 (24 Stat. 1; U.S.C., 1940 edition, title 3, secs. 21 and 22), are repealed." 


\section{Appendix C}

\section{The Twenty-fifth Amendment to the Constitution of the United States of America}

Proposed by resolution of the Congress on July 6, 1965; declared ratified by the legislatures of thirty-nine of the fifty States on February 23, 1967. Article $[\mathrm{XXV}]$

Section 1. In case of the removal of the President from office or of his death or resignation, the Vice President shall become President.

Sec. 2. Whenever there is a vacancy in the office of the Vice President, the President shall nominate a Vice President who shall take office upon confirmation by a majority of vote of both Houses of Congress.

Sec. 3. Whenever the President transmits to the President pro tempore of the Senate and the Speaker of the House of Representatives his written declaration that he is unable to discharge the powers and duties of his office, and until he transmits to them a written declaration to the contrary, such powers and duties shall be discharged by the Vice President as Acting President.

Sec. 4. Whenever the Vice President and a majority of either the principal officers of the executive departments or of such other body as Congress may by law provide, transmit to the President pro tempore of the Senate and the Speaker of the House of Representatives their written declaration that the President is unable to discharge the powers and duties of his office, the Vice President shall immediately assume the powers and duties of the office as Acting President. 
Thereafter, when the President transmits to the President pro tempore of the Senate and the Speaker of the House of Representatives his written declaration that no inability exists, he shall resume the powers and duties of his office unless the Vice President and a majority of either the principal officers of the executive department or of such other body as Congress may by law provide, transmit within four days to the President pro tempore of the Senate and the Speaker of the House of Representatives their written declaration that the President is unable to discharge the powers and duties of his office. Thereupon Congress shall decide the issue, assembling within forty-eight hours for that purpose if not in session. If the Congress, within twenty-one days after receipt of the latter written declaration, or, if Congress is not in session, within twentyone days after Congress is required to assemble, determines by a two-thirds vote of both Houses that the President is unable to discharge the powers and duties of his office, the Vice President shall continue to discharge the same as Acting President; otherwise, the President shall resume the powers and duties of his office. 